DISCLAIMER

This book was prepared as an account of work sponsored by an agency of the United States Government. Neither the United States Government nor any agency thereof, nor any of their employees, makes any warrenty, express or implied, or assumes any legal liabiliy or responsbiny tor he acaracy.

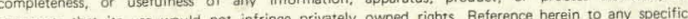
represents that its use wostd nor commertial broduct, process, or its its endorsement, recommendation, or favoring by the United

States Government or ary agency thereof. The views and opinions of authors expressed herein do not

necessarily state or reflect those of the United States Government or any agency thereot.

QUARTERLY PROGRESS REPORT

\title{
PHASE IV
}

DESIGN AND DEVELOPMENT OF

A CONTINUOUSLY VARIABLE RATIO TRANSMISSION

FOR AN AUTOMOTIVE VEHICLE

May 31,1978

Ref: ERDA-Orshansky Contract No. EY-76-C-03-1165, Modification No. A0O4

Submitted to: Energy Research and Development Administration Power Train \& Vehicular Systems Branch

Office of Highway Vehicle Systems Energy Conservation 20 Massachusetts Avenue, N. W.

Washington, D. C. 20545

By: Orshansky Transmission Corporation

5141 Santa Fe Street

San Diego, California 92109 


\section{DISCLAIMER}

This report was prepared as an account of work sponsored by an agency of the United States Government. Neither the United States Government nor any agency Thereof, nor any of their employees, makes any warranty, express or implied, or assumes any legal liability or responsibility for the accuracy, completeness, or usefulness of any information, apparatus, product, or process disclosed, or represents that its use would not infringe privately owned rights. Reference herein to any specific commercial product, process, or service by trade name, trademark, manufacturer, or otherwise does not necessarily constitute or imply its endorsement, recommendation, or favoring by the United States Government or any agency thereof. The views and opinions of authors expressed herein do not necessarily state or reflect those of the United States Government or any agency thereof. 


\section{DISCLAIMER}

Portions of this document may be illegible in electronic image products. Images are produced from the best available original document. 
TABLE OF CONTENTS

\section{Section}

I

II

Appendices

A

B

C

D

E

F

G

$\mathrm{H}$

I

J

K
Introduction

Task 22 - Task Technical Status Report

Test Data - Module Losses under No Load

Test Conditions for Module Noise Measurement

Effect of Drive Shaft Spline on Module Torque Losses

Test Data - Module Torque Losses and Volumetric Efficiency without piston hold-down plate

Measurement of Shaft Deflection while Assembled

Design of Bearing Pads for Hydrodymamic Wedge

Test Data - Module Torque Losses and Volumetric Efficiency at Reduced Variable-Unit visplacement

Test Data - Module Torque Losses, Volumetric Efficiency and Leakage with Increased Pịton Engagement

Test Data - Module Torque Losses, Volumetric Efficiency and Leakage with Increased Piston Engagement and with Maximum Variable Unit Displacement

Test Data - First Generation HMT Hydrostatic Module Noise Results

Project Review Meeting, April 11, 1978 - attendees, agenda, test drive transmission evaluation results 


\section{ORSHANSKY TRANSMISSION CORPORATION}

\section{INTRODUCTION}

Under Modification A004 to Contract EY-76-C-03-1165 the following tasks had been funded up to March 31 , 1978.

\section{$\underline{T a s k}$}

6 Development of the hydraulic and electronic control sub-systems..

16B Measurement of response rate of advanced auxiliary circuit concept to changes in auxiliary hydraulic power demand.

17 Road testing of demonstration vehicle with installed First Generation Hydromechanical Transmission.

22 Testing of Co-Axial Hydrostatic Module for Second Generation Hydromechanical Transmission.

30 Reporting.

33 Evaluation of noise shield for the hydrostatic module:

41 Documentation of design changes.

42 Evaluation of clutch control modifications for improved shift quality.

The major automotive hydromechanical transmission development problem continues to be the reduction of hydrostatic noise and the project plan therefore concentrated on the new hydrostatic module. The potential for achieving. acceptably low noise levels in the Second Generation .. hydromechanical transmission is to be assessed by comparing the noise levels of the hydrostatic modules for the first and second generation transmissions. A set of twelve test points were selected comprising of road load steady state and wide-open-throttle acceleration at $10,20,30,40,50$ and $60 \mathrm{mph}$. The module operating conditions for the two transmissions at each of these twelve points were calculated. Table B-l shows the conditions for the Second Generation Co-Axial Module dcsigned under this contract. Baseline noise data was measured on the First Generation Module; the results are given in Appendix $J$. 


\section{ORSHANSKY TRANSMISSION CORPORATION}

Schedule slippage and budget limitations indicated that all work should be concentrated on Task 22. Official notification of this decision was received on April 13 but re-orientation of effort had in fact started in early March. During the current reporting period, therefore, funded work was devoted to Task 22 - module development, and Task 30 - reporting.

On April 11, a project review meeting was held at the Orshansky Transmission facility, San Diego. A list of attendees and the agenda are given in Appendix $\mathrm{K}$. The transmission development status was evaluated by N. Postma and $T$. Stockton of Ford Motor Company by test-driving the demonstration car in which a First Generation transmission prototype has been installed. The test ratings are given in Appendix $\mathrm{K}$ along with results for similar ratings in October 1976 and October 1977. It may be seen that the noise evaluation improved although noise for acceleration still is significantly below the acceptability rating of 5 . The General Appraisal improved slightly from a rating of 3 in October 1977 to 3.5 in April 1978.

A final report from Ford Motor Company, as a subcontractor, is expected at the end of September, when noise data from the Second Generation hydrostatic module should b e available for comment. 


\section{TASK 22}

A series of tests were conducted with the variable unit as a pump ( $\mathrm{H}_{\mathrm{VP}}$ ) and the fixed unit as a motor $\left(\mathrm{H}_{\mathrm{FM}}\right)$. With the $\mathrm{H}_{\mathrm{VP}}$ set at maximum displacement, data was recorded at input speeds of zero to $1600 \mathrm{rpm}$ in $400 \mathrm{rpm}$ increments, while charge pressure was varied from 50 to $400 \mathrm{psi}$ in 50 psi increments. These tests were conducted with the output drive shaft disconnected, such that pressure developed by the pump was only sufficient to overcome friction in the $\mathrm{H}_{\mathrm{FM}}$ unit.

The same series of tests were conducted with the $\mathrm{H}_{\mathrm{VP}}$ displacement set at zero, $\left(D_{v}=0\right)$. This removes both piston friction and cylinder block tipping moments. To further assure that the pump would do no effective work, (in case it was not set exactly to zero displacement), the low and high pressure ports were each connected to charge pressure.

All of the above data was cross-plotted, but did not divulge any specific solution to the valve plate scuffing, nor the excessive leakage problem. Data sheets and curves are included in Appendix A.

Road load noise tests were run, since this involved maximum speed of $1400 \mathrm{rpm}$ on each unit, and a maximum pressure of about $650 \mathrm{psi}$. This . was to be used for comparison to lst generation unit, and as a base-line for noise reduction work to follow. See Appendix B for data.

First maximum power noise test point was for $50 \mathrm{mph}$ conditions, with $\mathrm{H}_{\mathrm{FP}}$ at $1168 \mathrm{rpm}, \mathrm{H}_{\mathrm{VM}}$ at 3500 and pressure about 1900 psi. This test was completed successfully without valve plate damage. After running $40 \mathrm{mph}$ maximum power point, $H_{F P}$ at $2335 \mathrm{rpm}, \mathrm{H}_{\mathrm{VM}}$ at $3500 \mathrm{rpm}$ and pressure of 2250 psi, the variable value plate (motor) was in good condition, but the fixed (pump) valve plate had been damaged.

Observation of the "blued" splines had led to the condlusion that they 


\section{ORSHANSKY TRANSMISSION CORPORATION}

were not being properly loaded. A set of spare shafts had been checked and the crown center-line was in the center of the spline, approximately 0.25 inches from point specified. These were returned to the vendor for rework, which required removal of material and were returned undersize, which increased the backlash. Additional backlash was deemed more acceptable than loading in such a manner that a couple was created in the cylinder block, whose reaction was at the valve plate coincident with the nominal position of reaction for the piston centrifugal moment. These were installed and tested with a total torque loss reduction of about 100 lb-in. at 2500 psi total pressure as shown in Appendix C.

Further visual inspection of spline contact points did not appear to be as expected and several modifications were made, one at a time, and in general, to only one unit at a time. These included reducing $0 . D$ of spline by 0.010 in.; removal of 0.190 in. from swashplate end of cylinder barrel spline; removal of $0.45 \mathrm{in.}$ of valve plate end of cylinder barrel. spline; providing additional clearance for cylinder barrel spring; switching rotating groups in units; switching valve plates; and testing variable pump - fixed motor, then fixed pump - variable motor. Valve plate damage continued to occur and although slight improvement in torque loss and leakage were accomplished, it became significantly obvious that the high torque losses were always associated with the pumping unit, whether it be fixed or variable.

Up to this point, the high torque loss and excessive leakage was generally assumed to be associated with the same unit. This could occur with one side of the cylinder block lifting, causing leakage while driving the other side thru the oil film, creating friction. Minor modifications were made to the hardware to prevent inter-unit leakage, such that leakage rate of each unit could be observed.

Under laboratory conditions, a steady flow of charge oil was predictable, 
therefore the shoe hold-down plate was not required. This plate was removed during the next run only to ascertain whether or not this could possibly be contributing to the high torque loss. Results showed torque loss to be even higher without the hold-down plate. Oil was collected from each case drain, and weighed. With the variable unit as a pump leak was $140 \%$ of the fixed motor leakage, see Appendix D. Switching valve plates gave essentially the same results.

A fixture was made to check shaft deflection while assembled, see Appendix E. Predicted deflections were higher than those measured, and was due to the fact that spline teeth and shoulders were not used in calculations. Since even the predicted values were less than found in most production units, this was deemed to not be a contributor to torque loss or leakage problem.

$65 \#$ springs were installed to replace the original 120 \# springs. This reduced the pump torque loss slightly, and pump leakage was now only some $70 \%$ of the motor leakage.

All tests to this point had been run with the high pressure kidney on the side opposite the actuators. It was reasoned that if case deflections were creating a problem, the results would be changed if the kidney on the same side as the actuator were pressurized. This was tested with no significant change in results.

Variable cylinder block bearing pads were relieved by 0.0005 in. which reduced the pump torque loss and improved the volumetric efficiency slightly. 'This same modification was then made to the fixed unit, and the variable unit was modified to give 22 tapered land pads as shown in Appendix F. This test gave essentially same results as earlier tests. 
Hardware inspections have never revealed any evidence of excessive piston friction, yet this too had to be thoroughly investigated. For the first test, the displacement of the variable unit was set at 1.835 in $3 / \mathrm{rev}$. Testing at the same input speed and pressure as the last test, the module will still have the same axial loads. Both units will have lower piston velocity, but for different reasons. The variable unit will have shorter stroke, and the fixed unit will have lower rotational speed. This resulted in a significant reduction of input torque loss and was tested to pressures of $4000 \mathrm{psi}$, without valve plate damage. When operating at pressures above $3500 \mathrm{psi}$, the fixed unit case drain was pulsating severely. This implied cylinder block/valve plate separation and re-seating, which could be attributed to the lighter springs. The 120 \# spring was installed in the fixed motor only and re-tested, with considerable reduction in motor leakage. Data and curves for this series of tests are included in Appendix G, and an inter-office memo discussing piston friction in greater detail. Relieving cylinder bores at T.D.C. had no significant effect on either leakage or notor torque loss.

Hardware was modified to permit moving the fixed unit cylinder barrel towards the swashplate to give more piston engagement at B.D.C. This change appeared to reduce motor torque loss, particularly at higher pressures. The variable pump displacement was set at $2.876 \mathrm{in}^{3} / \mathrm{rev}$, and a set of data points taken, then the unit was turned around to run the fixed unit as a pump. With the two units at essentially equal displacements, comparison of these two runs should permit better evaluation of the effect of more piston engagement at B.D.C. Input torque loss was definitely reduced with better piston engagement, so similar modifications were made to the variable unit, and with 120 \# springs in each unit, the total torque loss (including tare. loss) was very close to the predicted value. The volumetric efficiency, however, was some $6 \%$ lower than predicted at $3500 \mathrm{psi}$. Although total torque loss looked quite good, the distribution between pump and motor losses does not appear as 


\section{ORSHANSKY TRANSMISSION CORPORATION}

predicted. Results of this test are included in Appendix $\mathrm{H}$.

Displacement of the variable unit was increased to $3.04 \mathrm{in}^{3} / \mathrm{rev}$, to increase the piston stroke, and retract more of the piston at B.D.C. Changes, if any, from previous run were very hard to detect. Input speed was increased to $2333 \mathrm{rpm}$ and although torque losses were greater than at $1166 \mathrm{rpm}$, they were in very close agreement to the predicted value, and volumetric efficiency was still $5 \%$ low, as shown in Appendix I.

With units at maximum displacement, testing up to 4000 psi and 2333 input speed could be accomplished without severe damage to the valve plates. Tare losses were measured, and when these were accounted for, the module torque loss was slightly less than predicted.

\section{FUTURE TEST PLANS}

Investicate possibility of additional piston engagemert at B.D.C. Make new fixture to facilitate more accurate measurement of piston strokes, thus displacement of units, since these directly affect both torque loss and volumetric efficiency calculations. Test to see if module can be run at higher speeds and pressures so that noise data can be recorded for maximum power settings. 


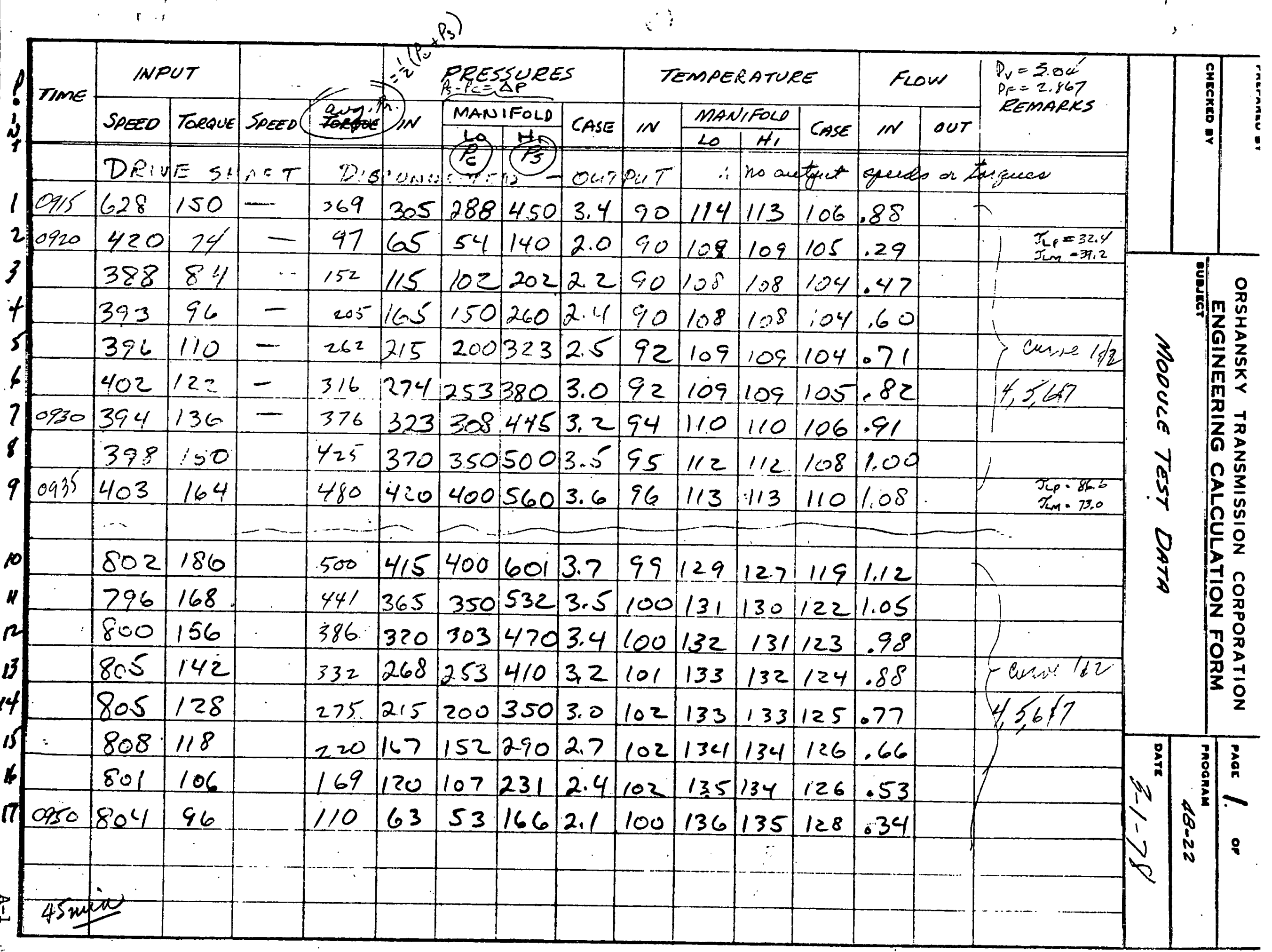




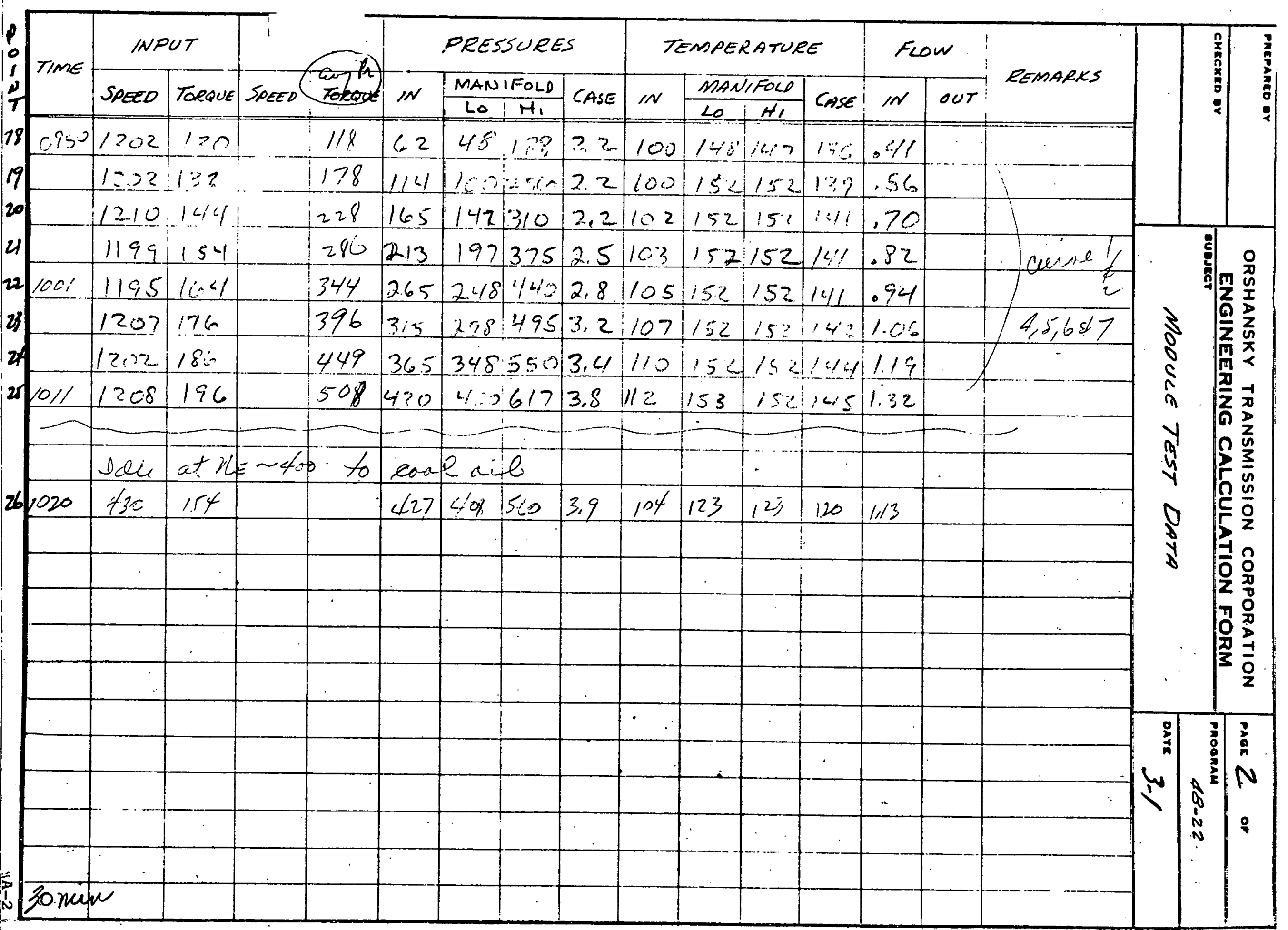




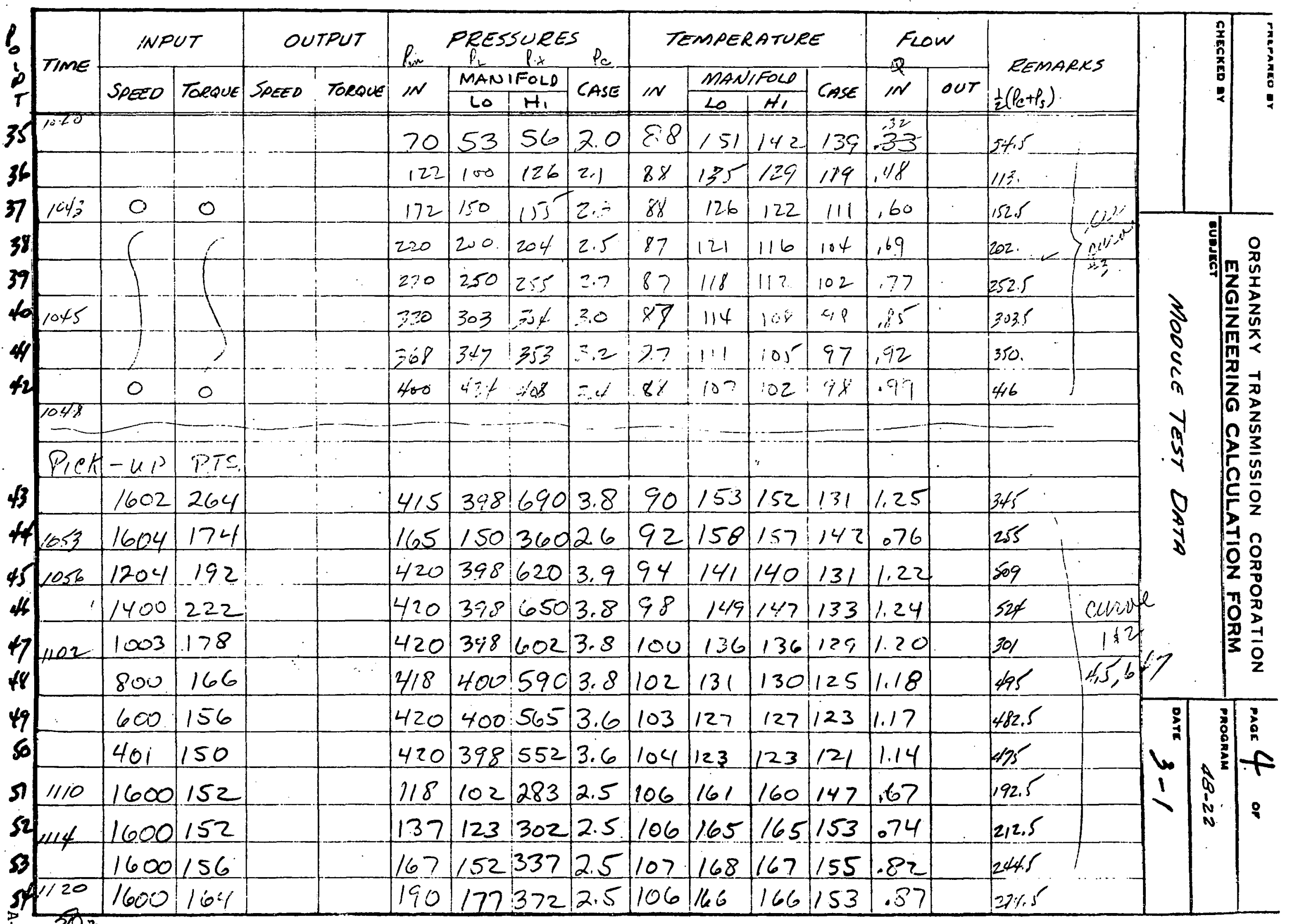




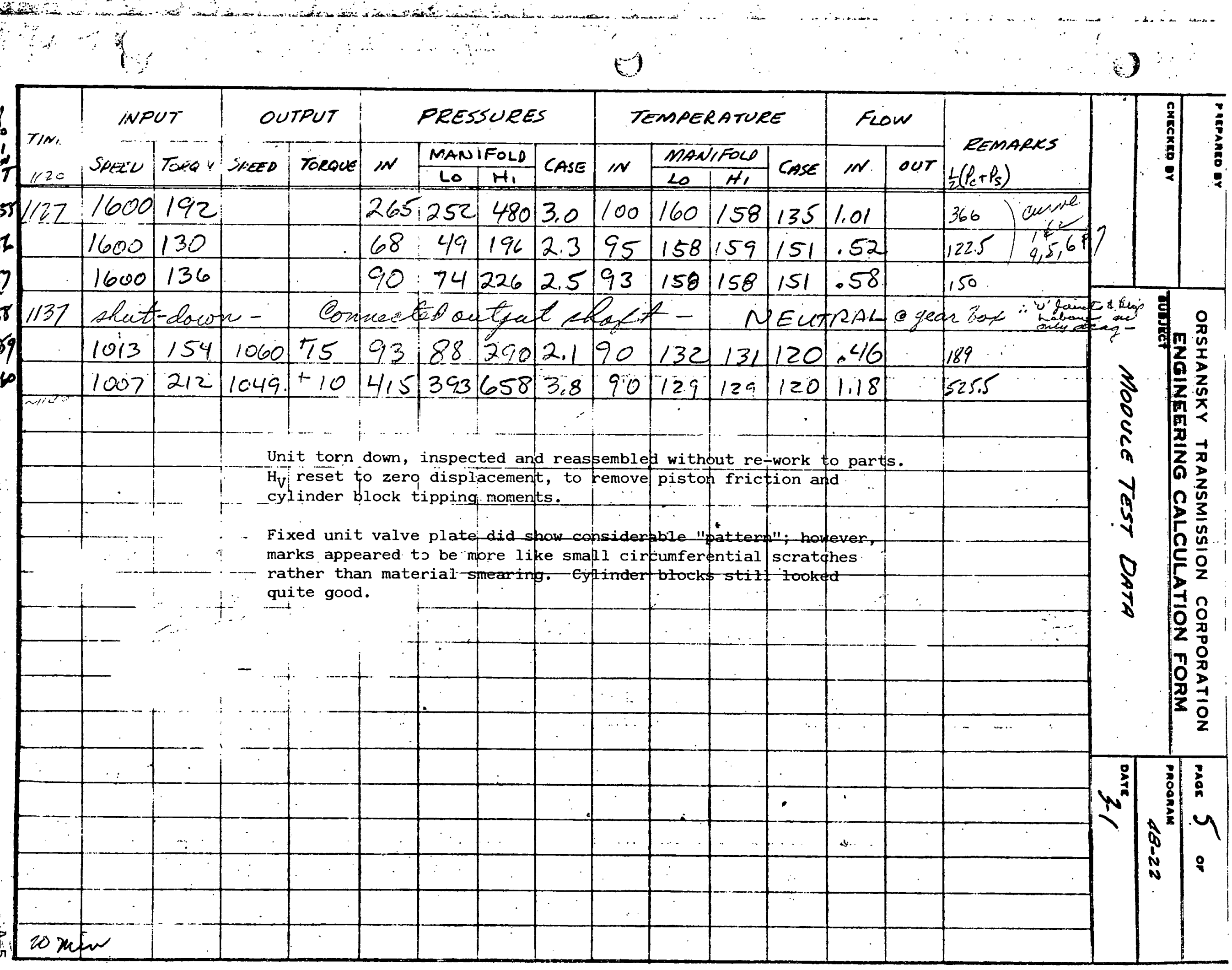




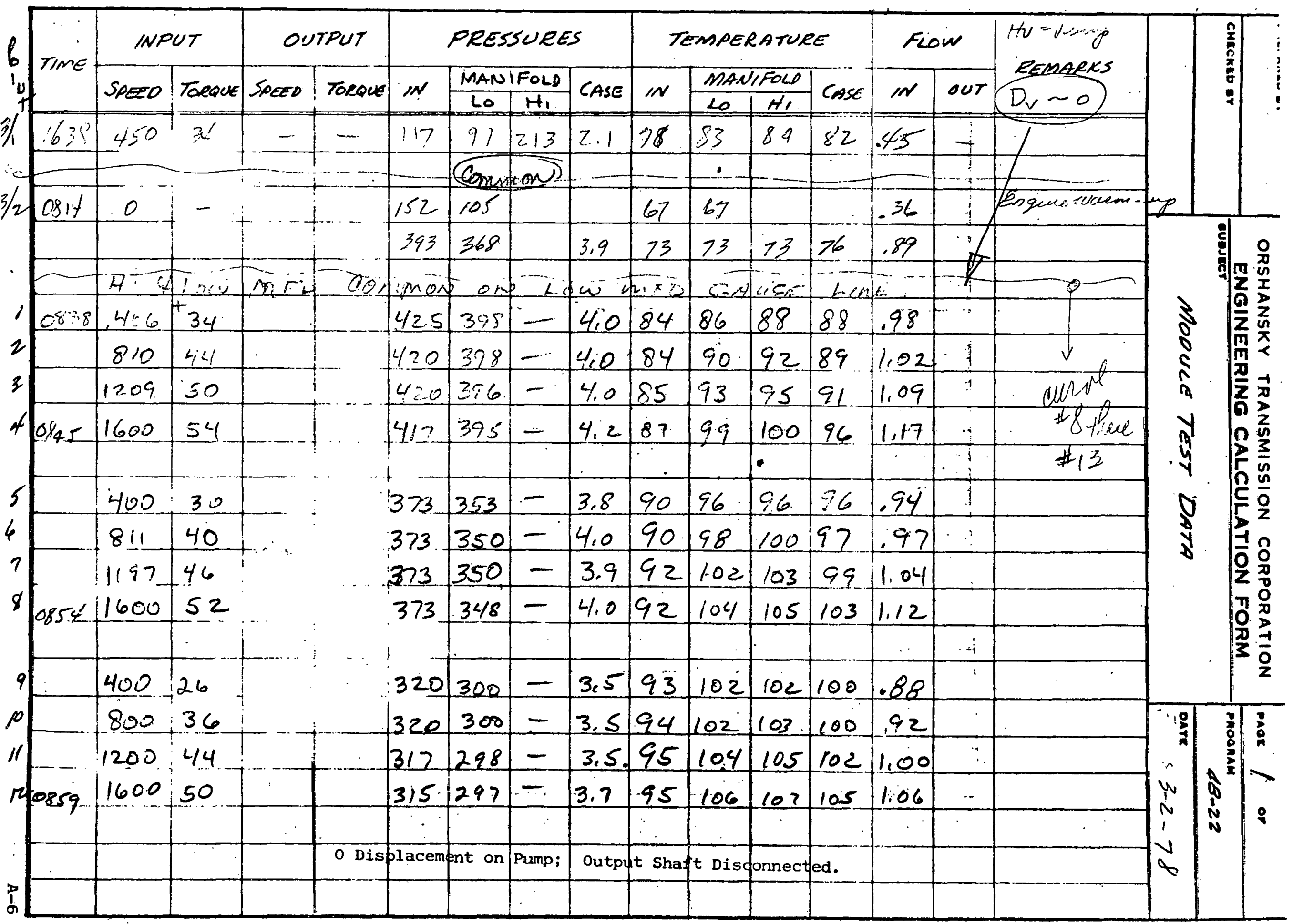




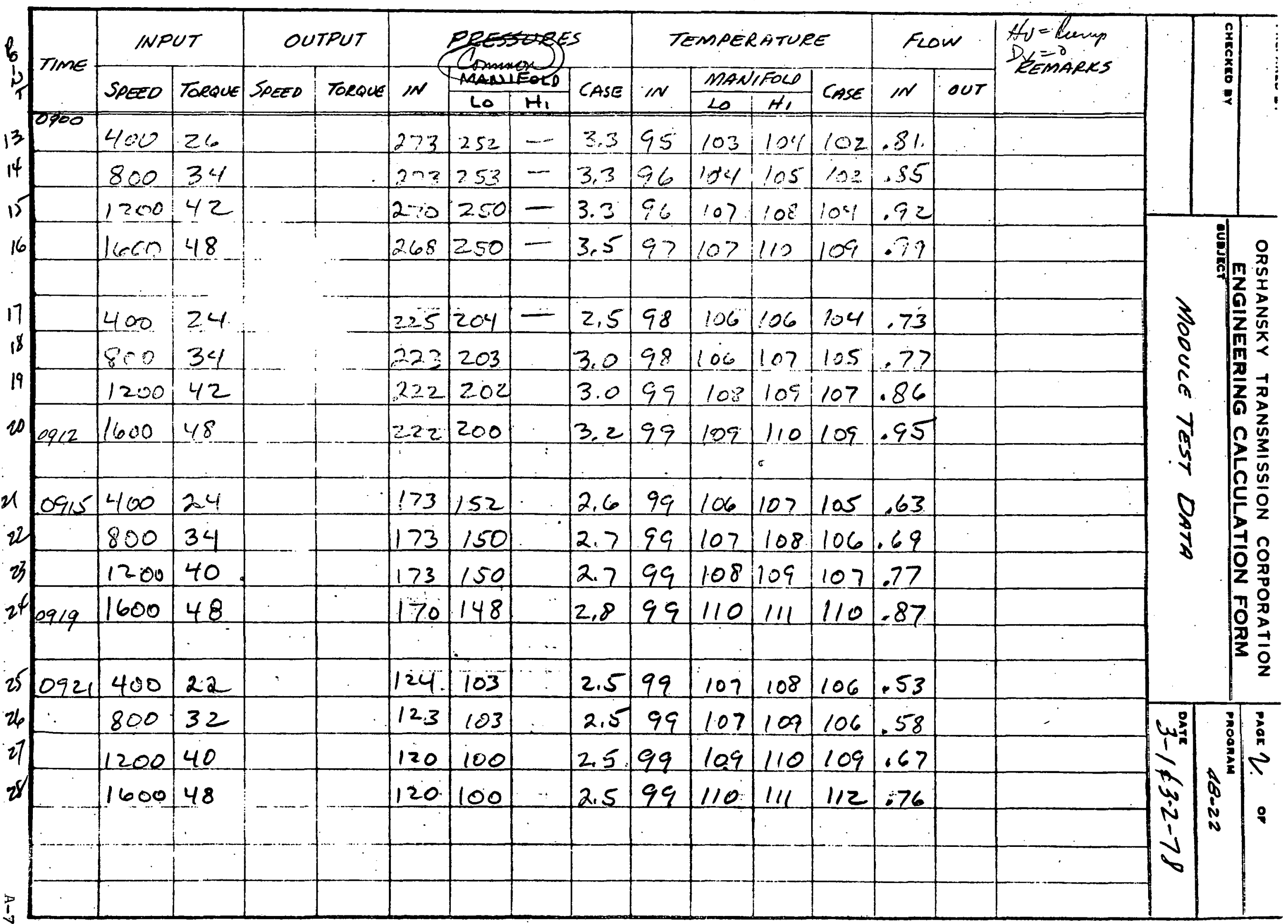




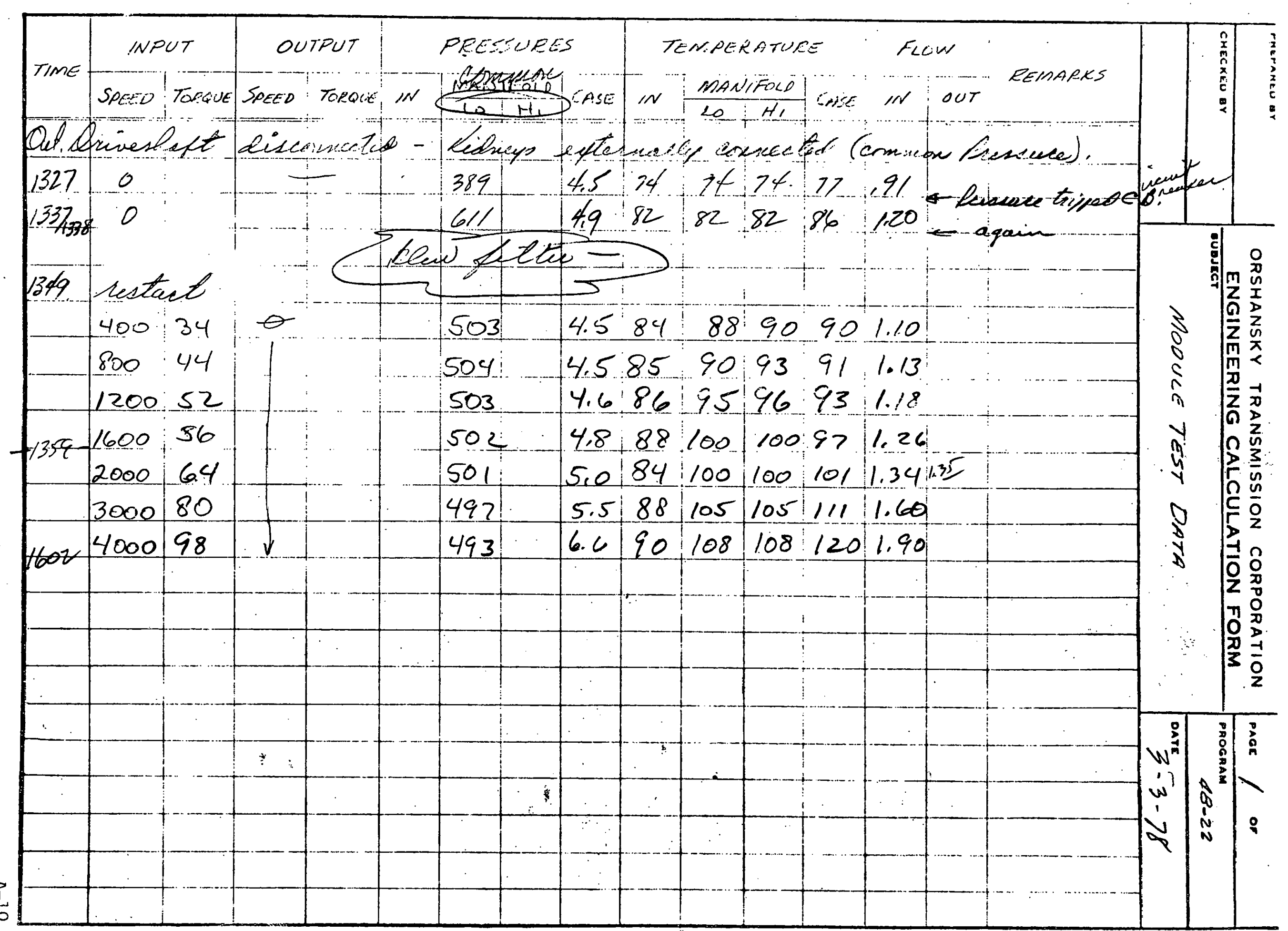




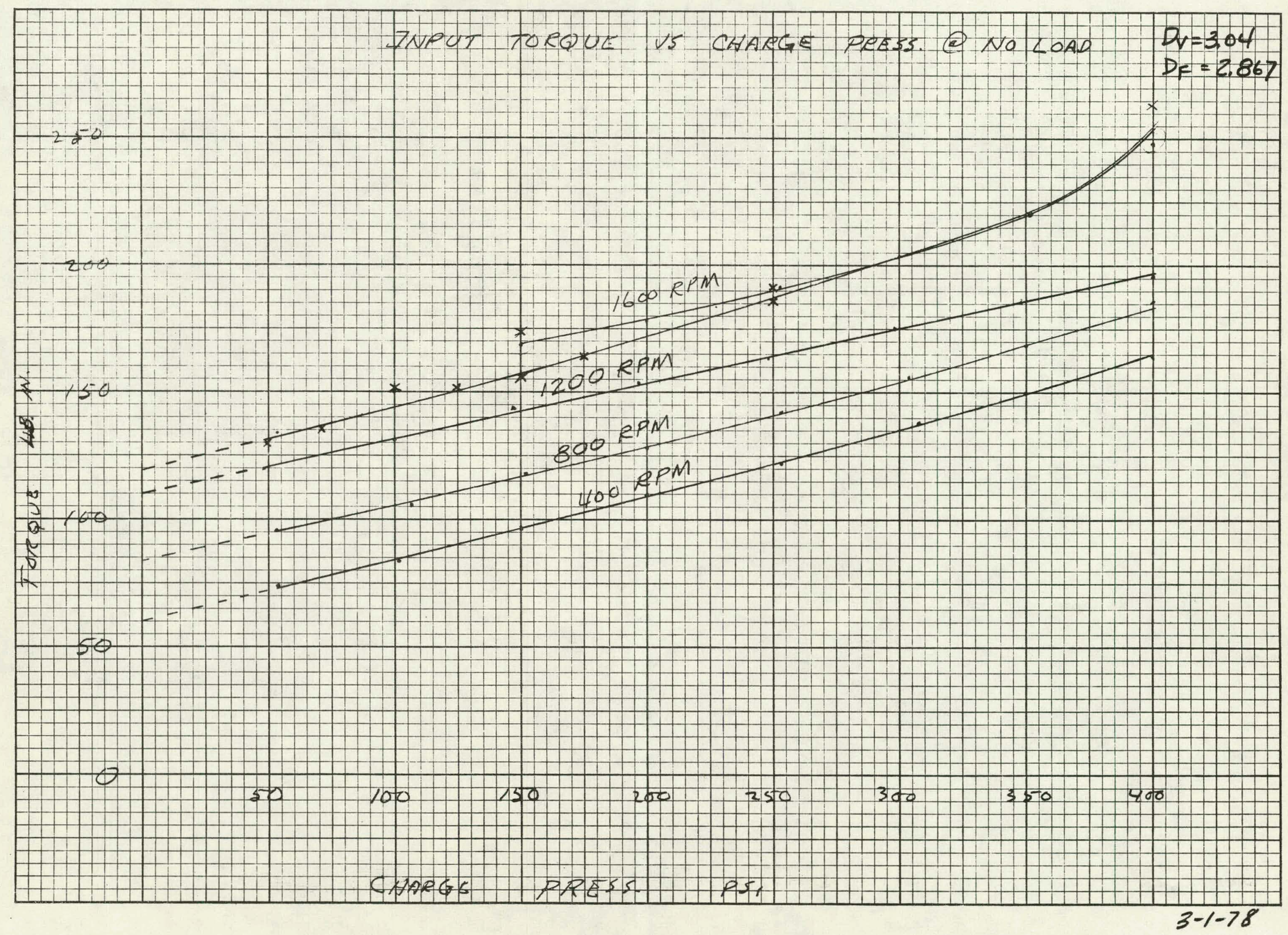


K=E $\begin{aligned} & 10 \times 10 \text { TO THE INCH } 46 \text { O780 } \\ & 7 \times 10 \text { INCHES }\end{aligned}$

KEUFFEL \& ESSER CO.

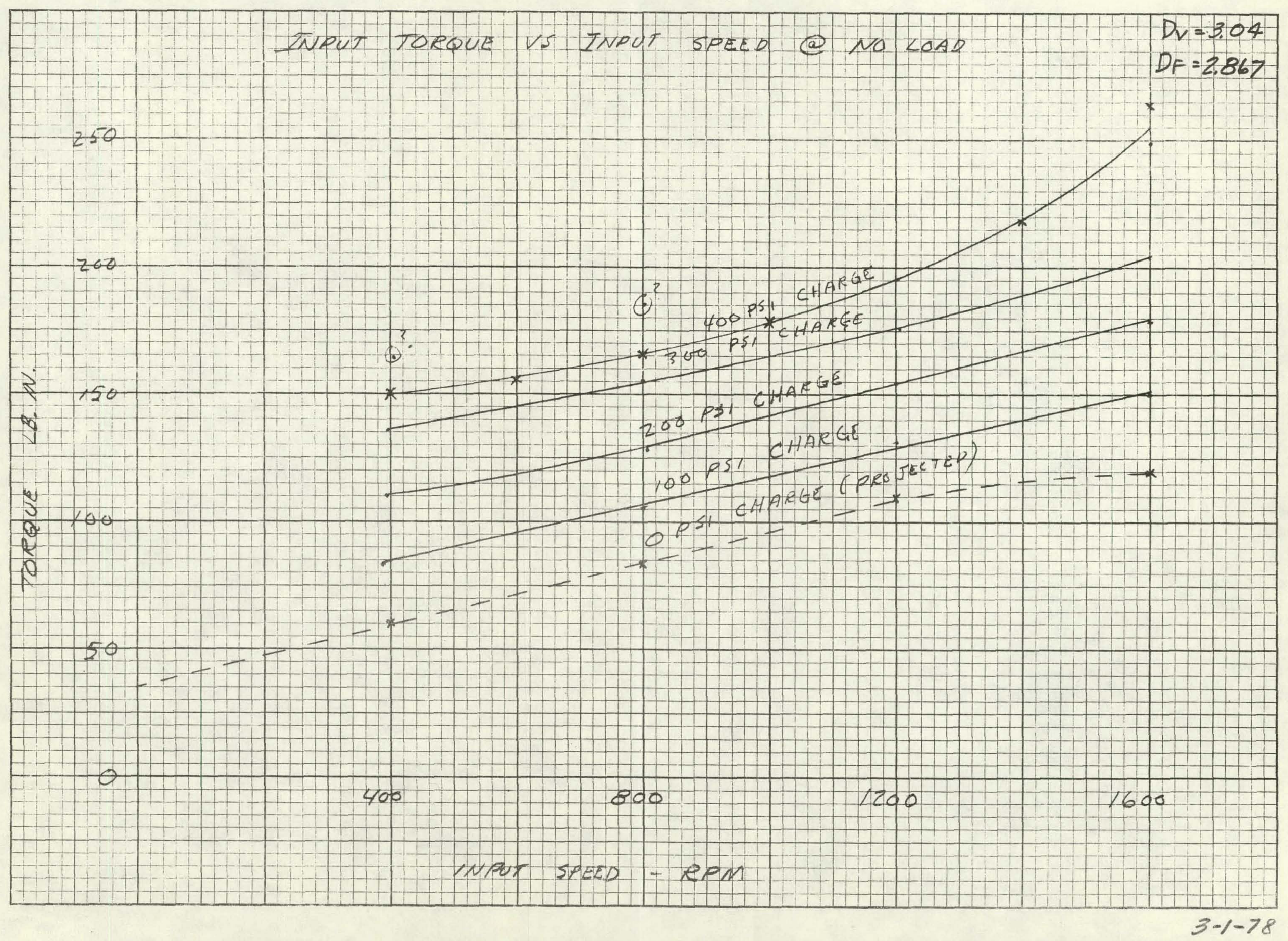




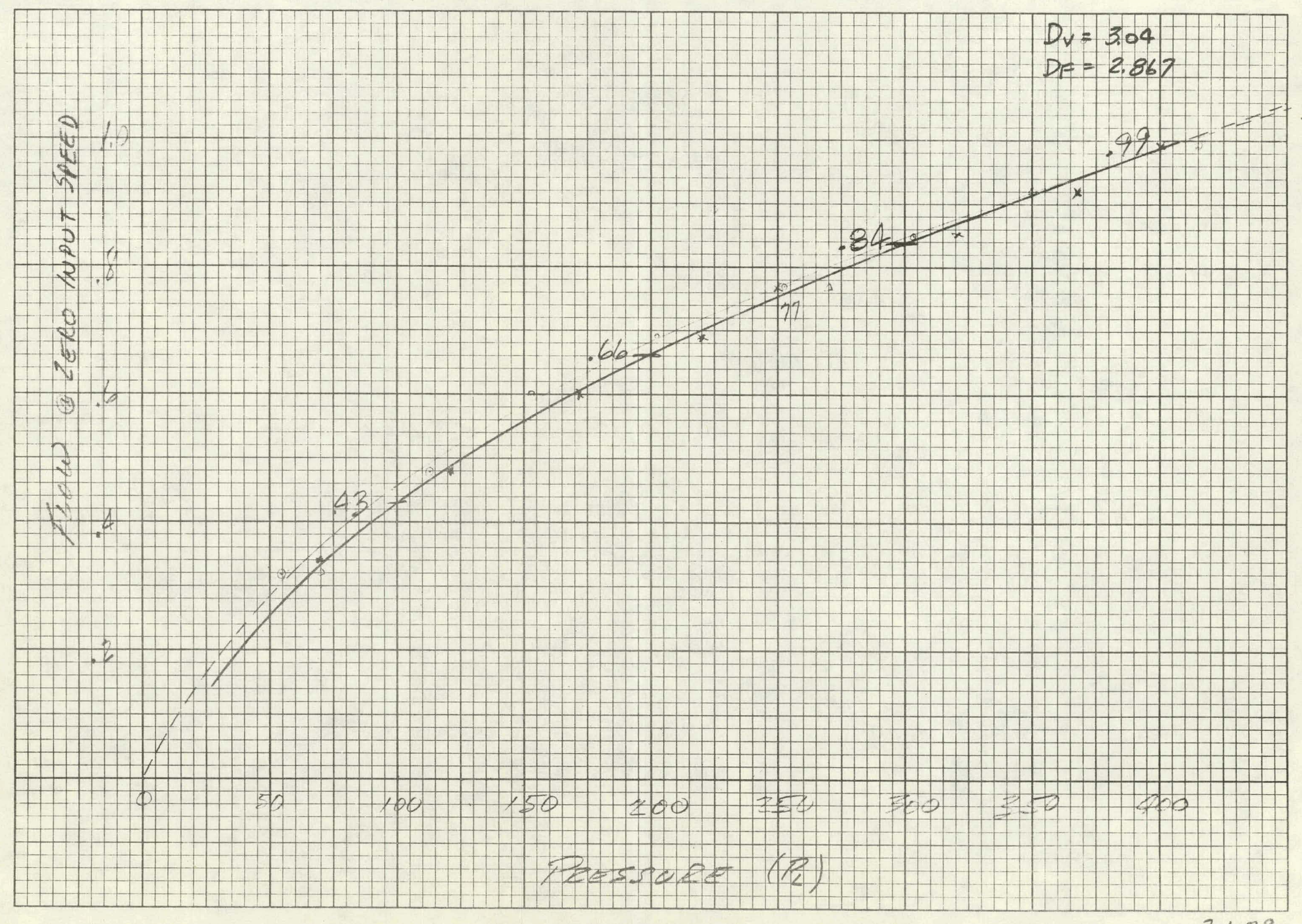


4 Leakage at here lass Leakcen at bero speed

Aleakage vs lnput speid e constant pressure

$D_{Y}=3.04$

$D F \cdot 2 \$ 6 ?$

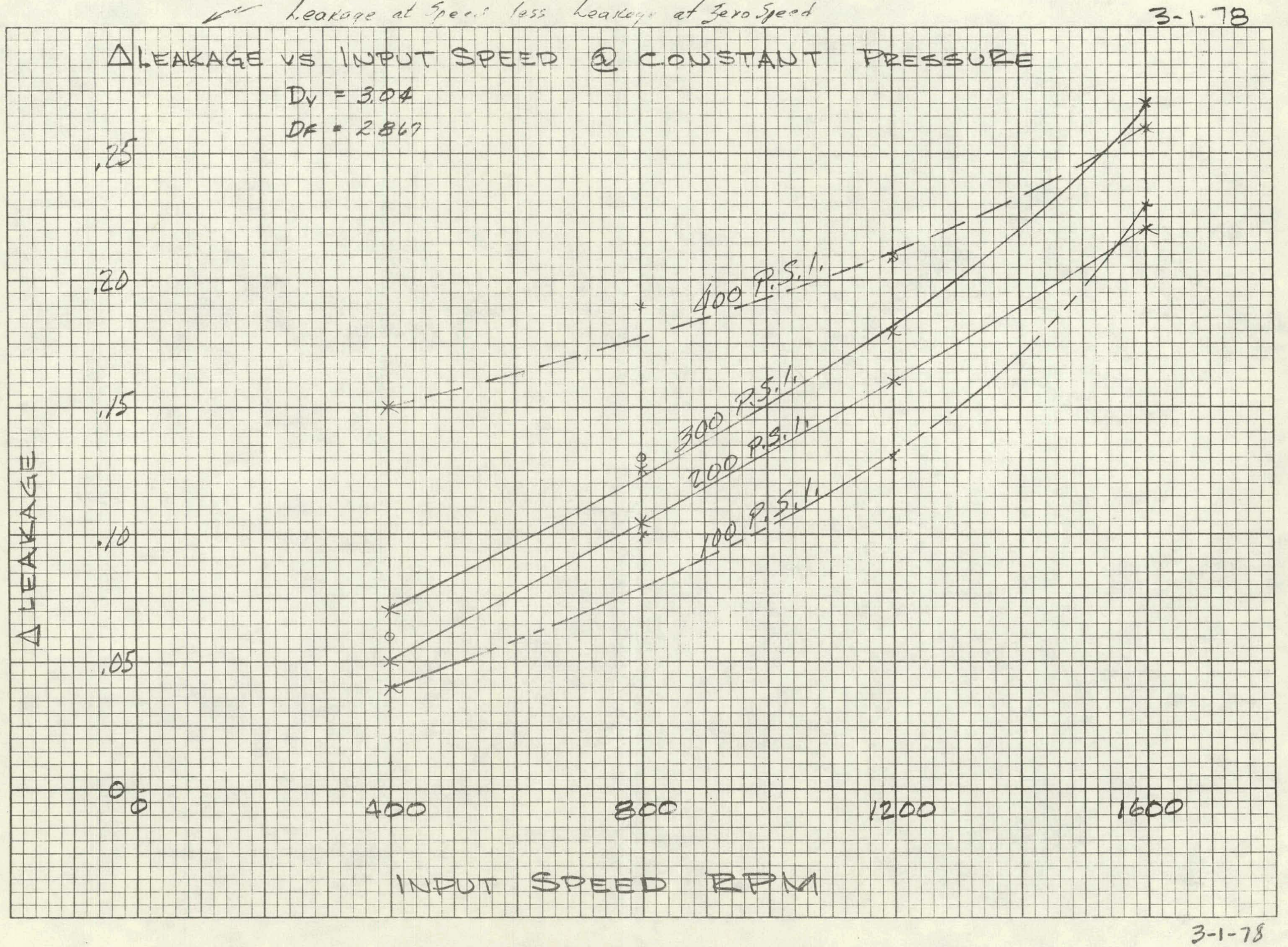

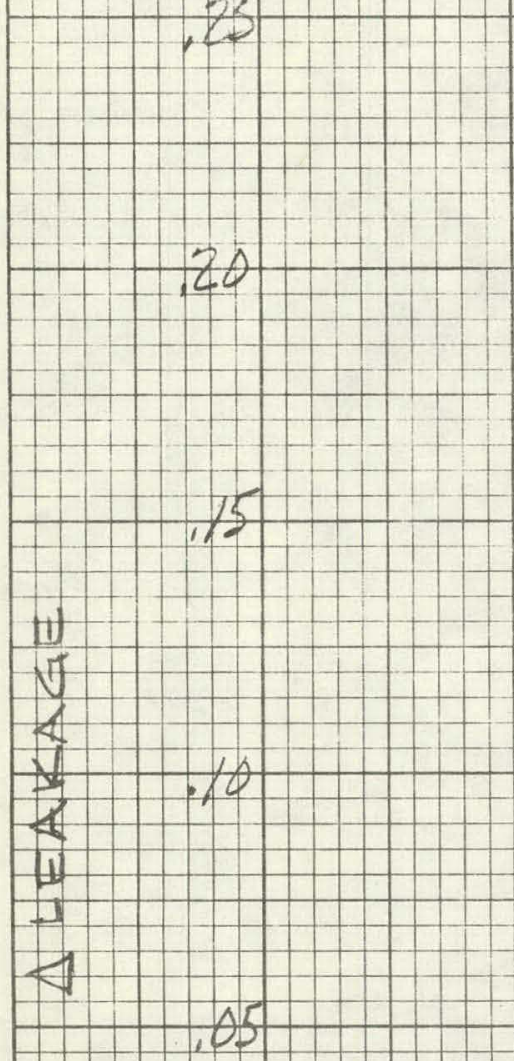


$3-1-78$

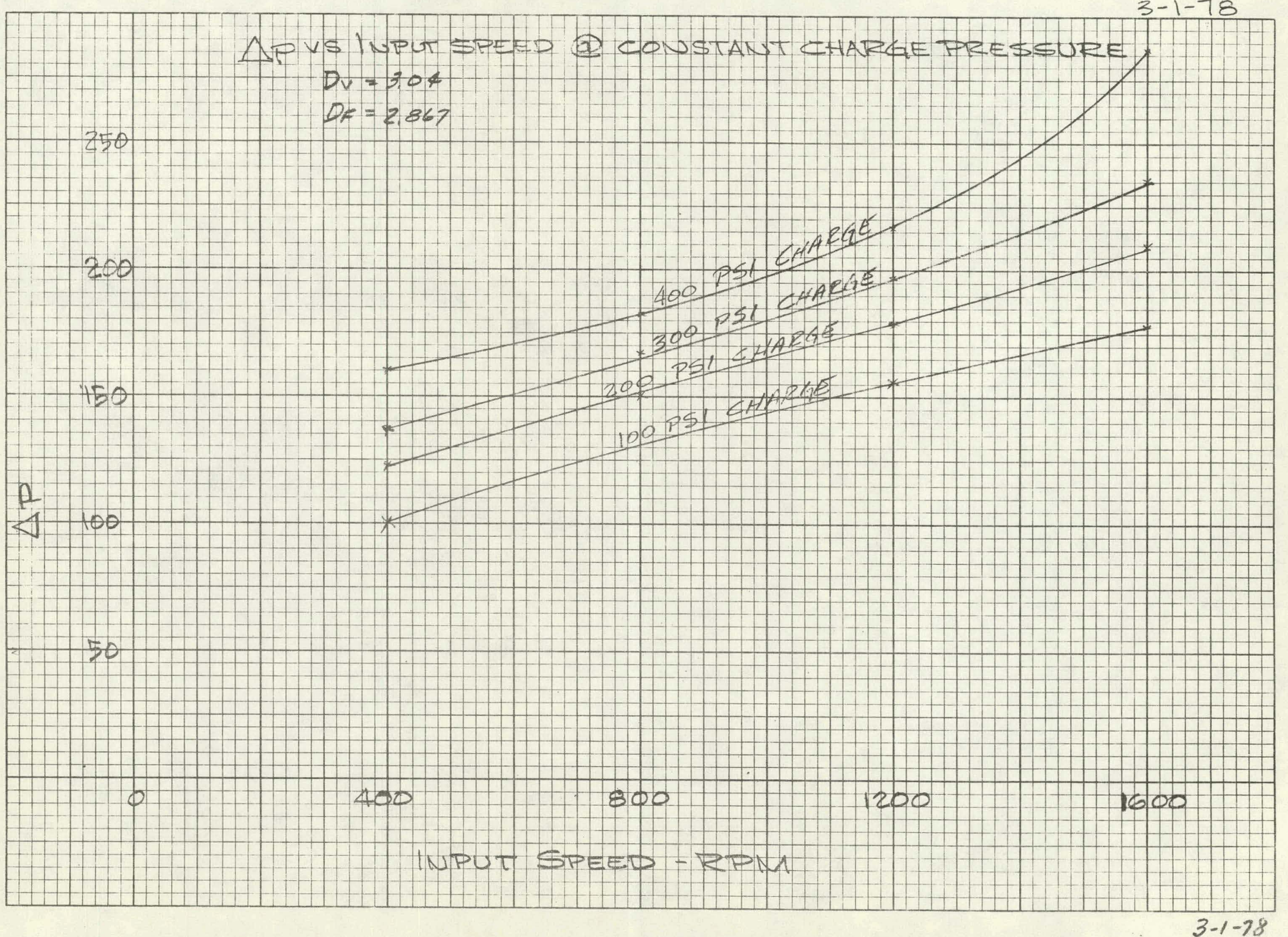




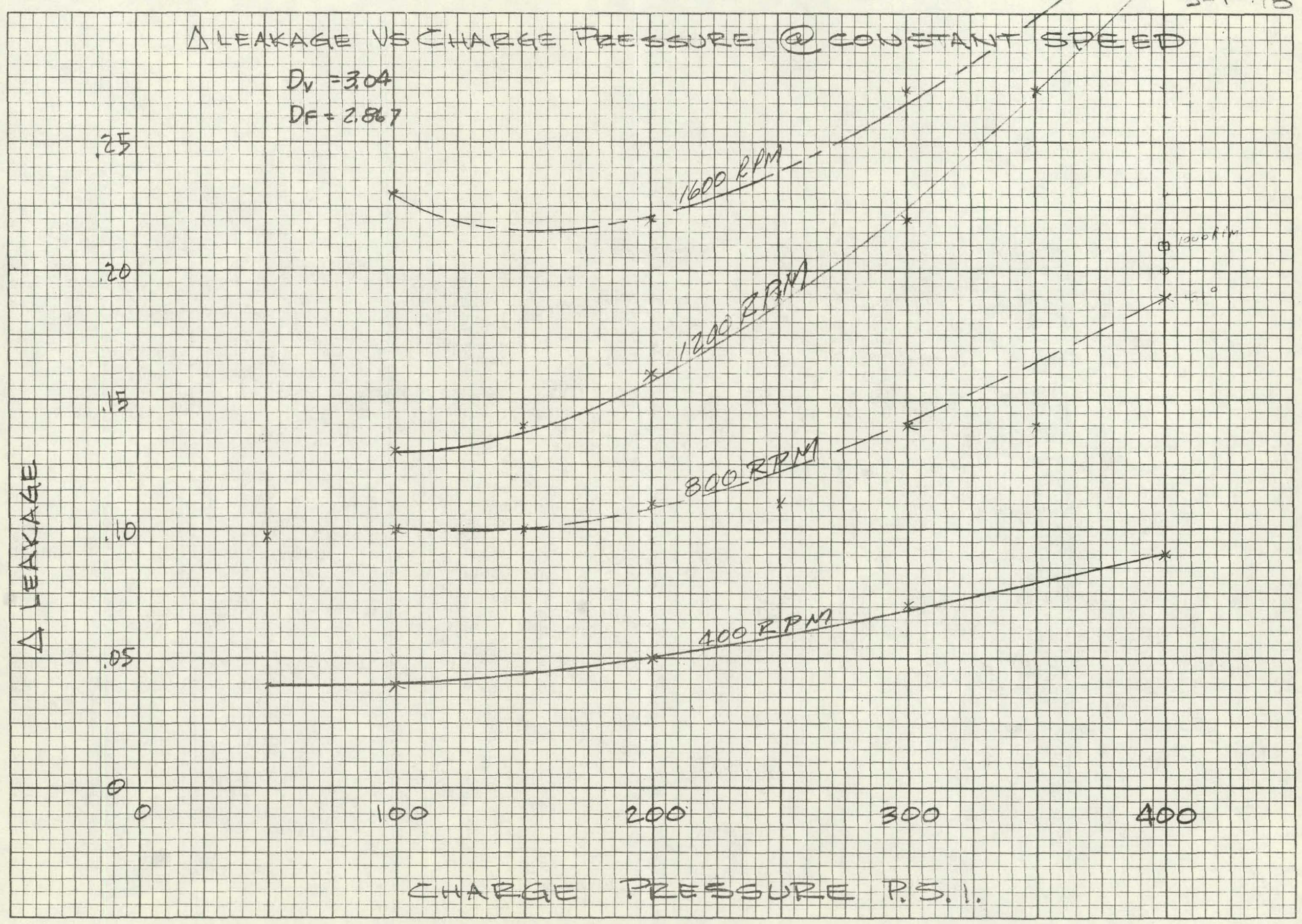




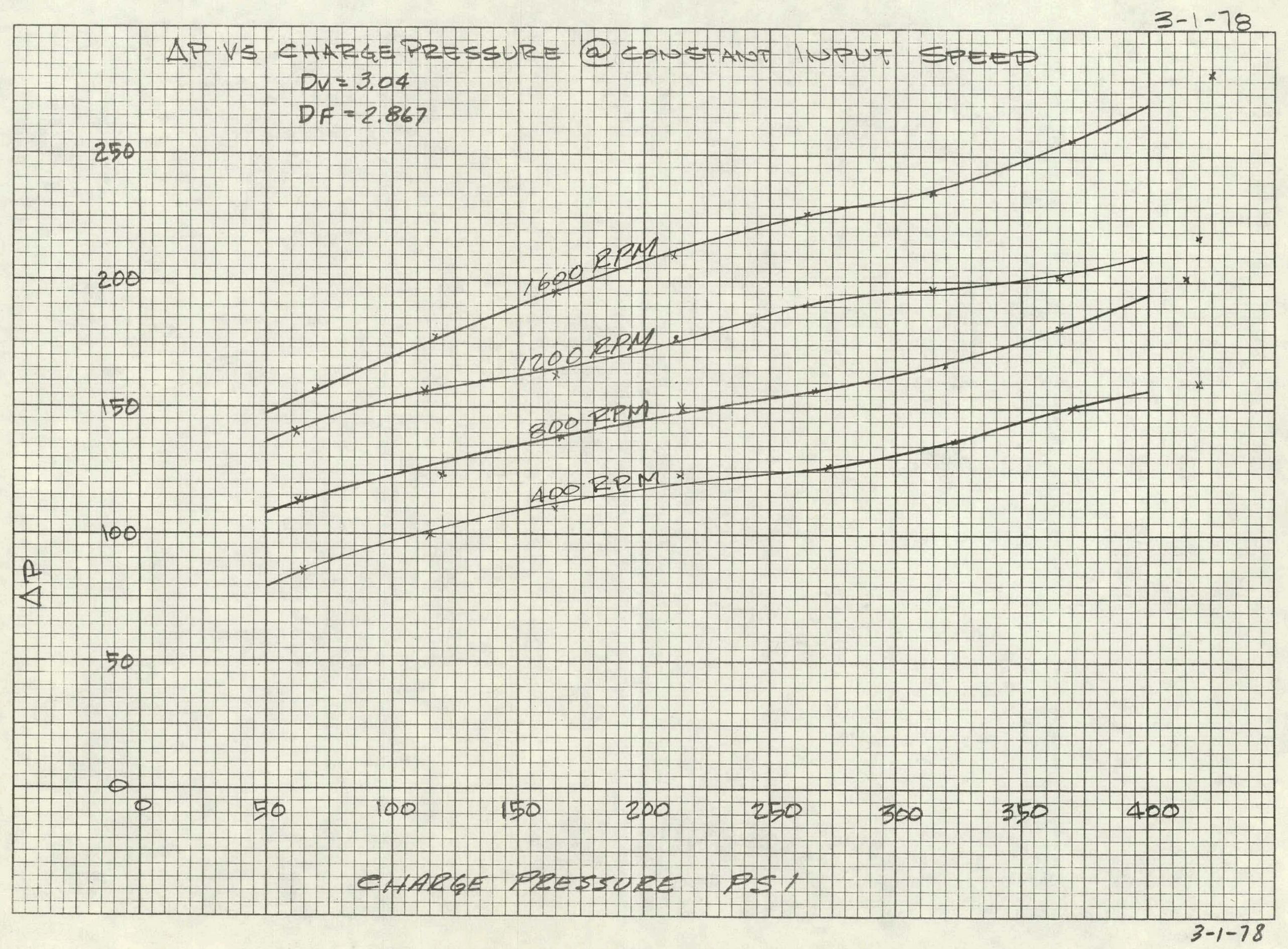




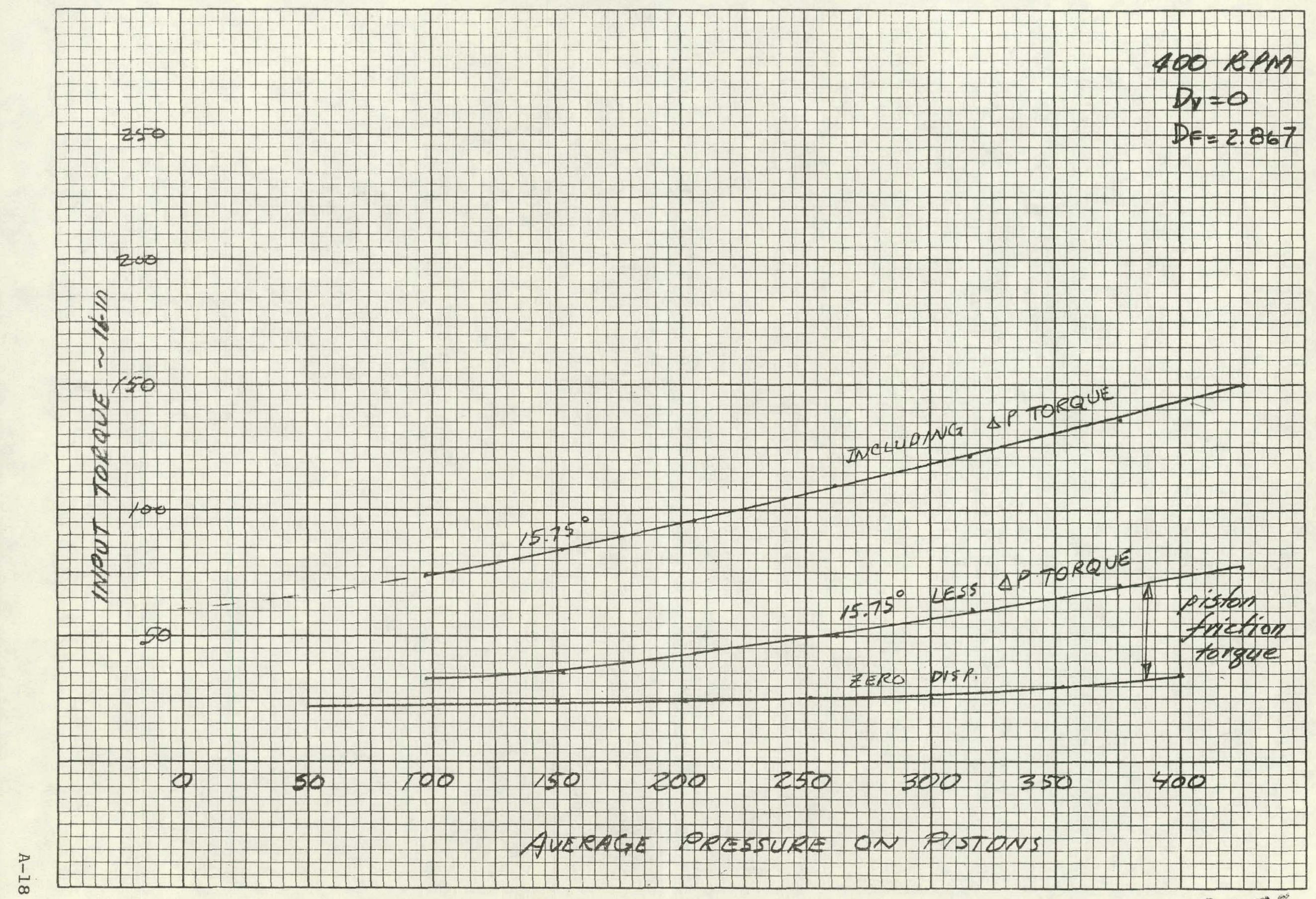




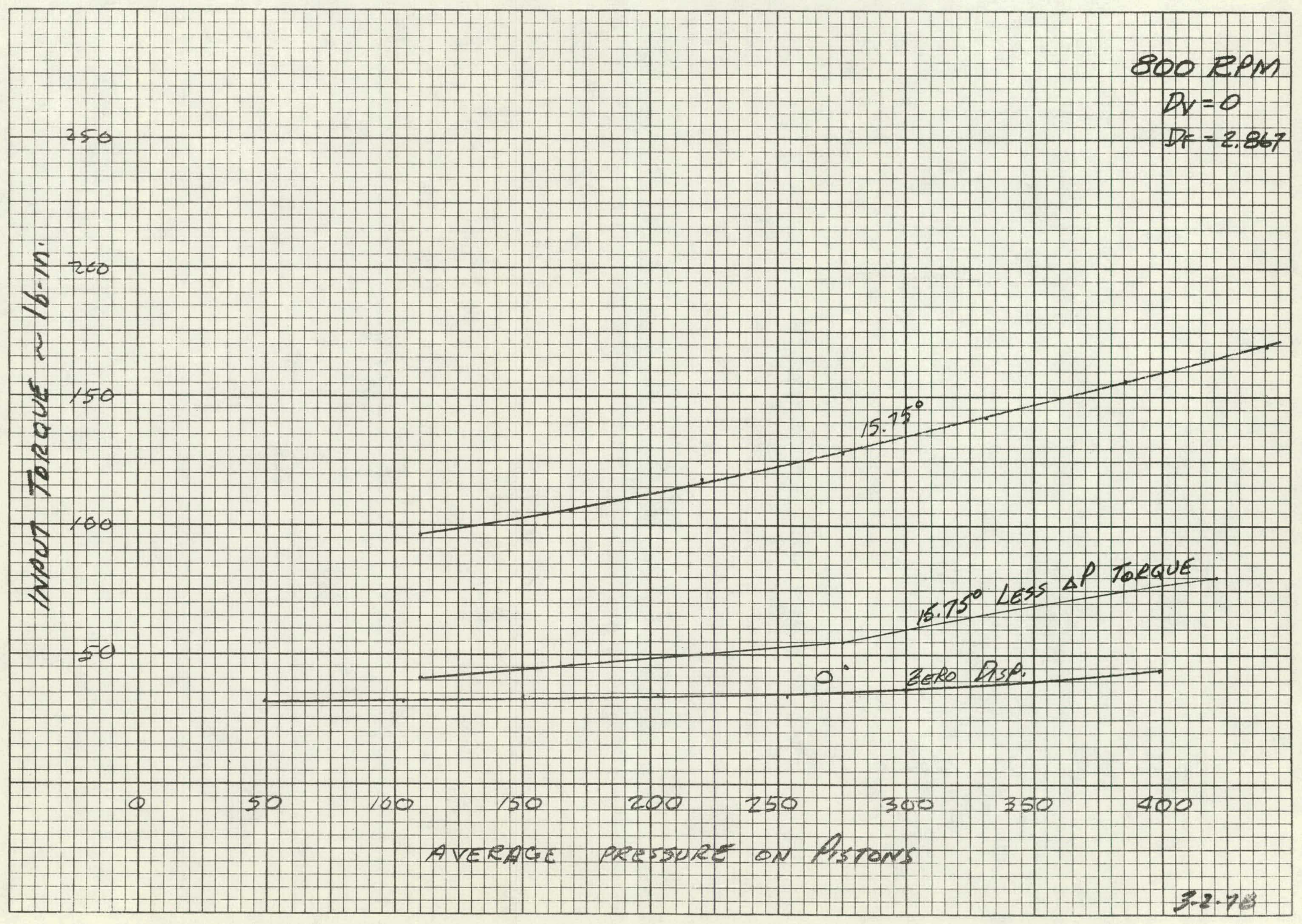




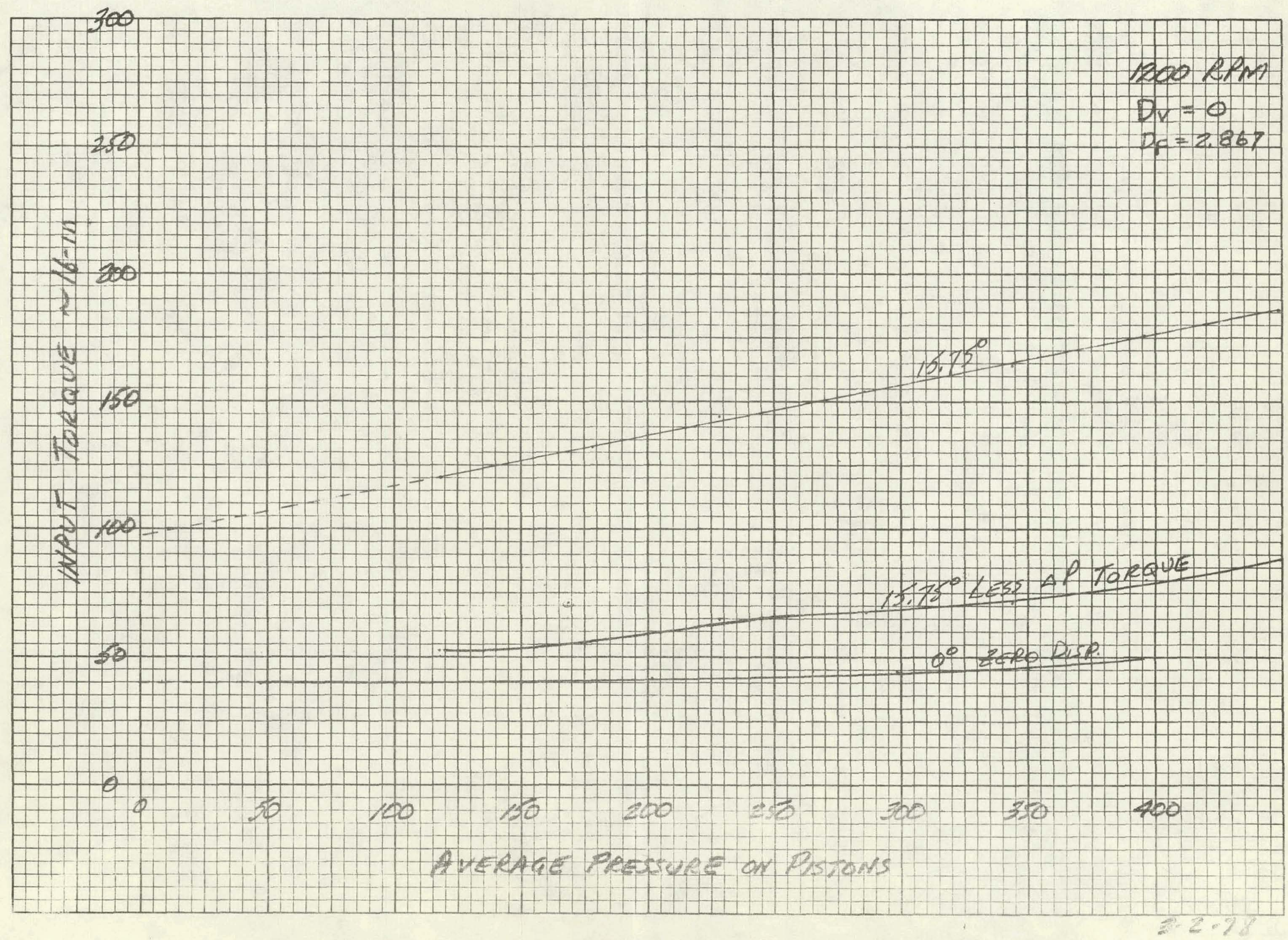




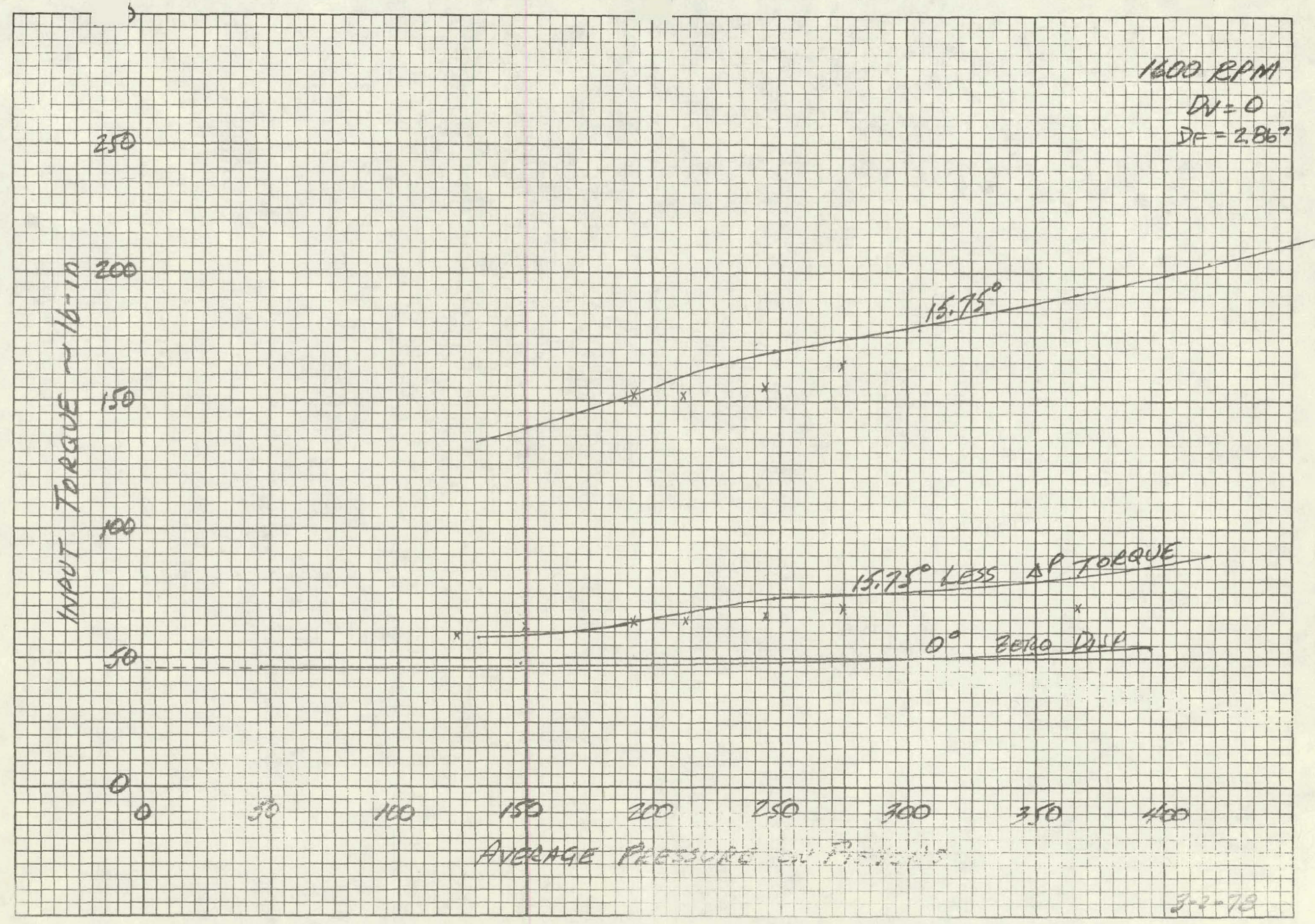




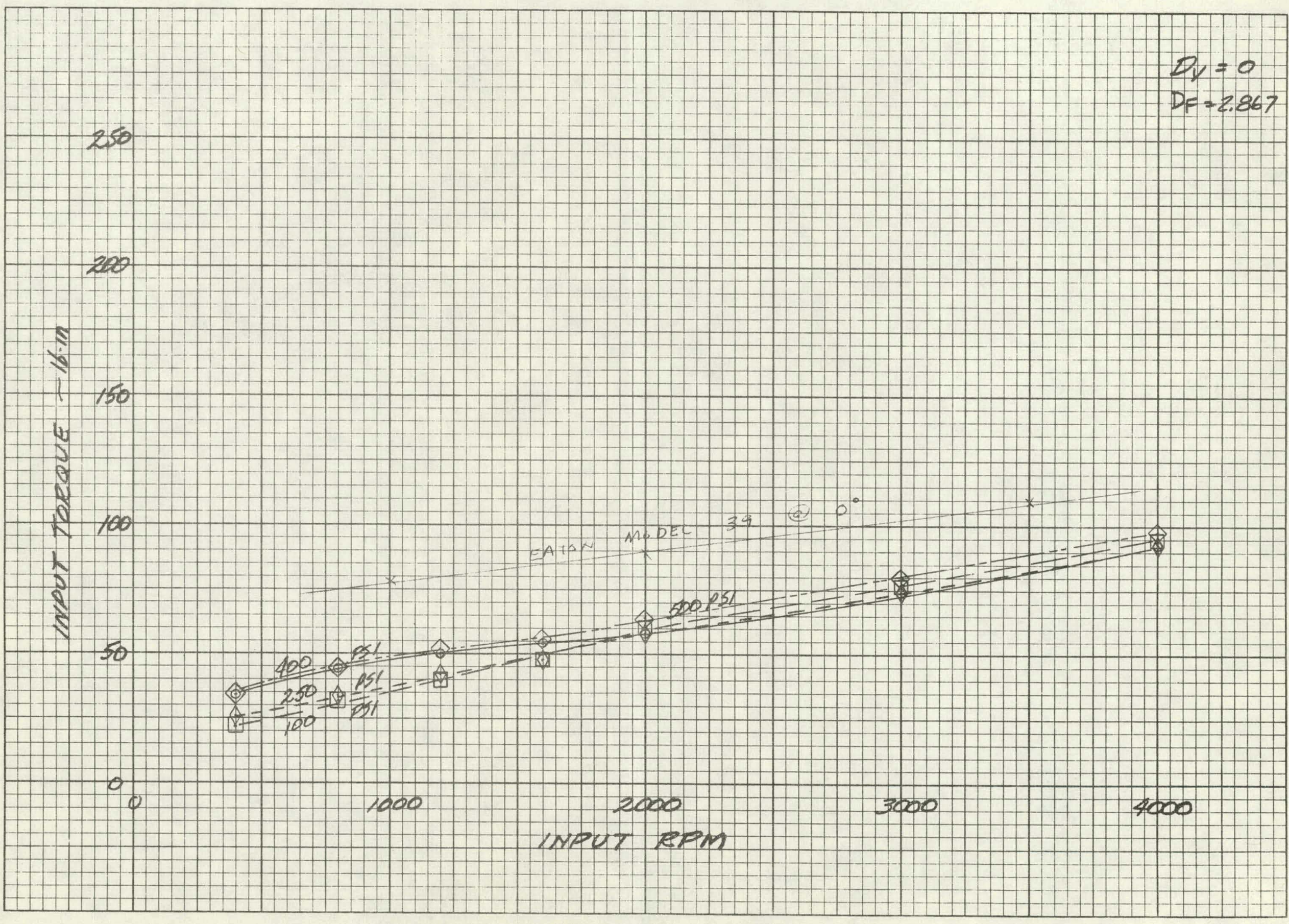




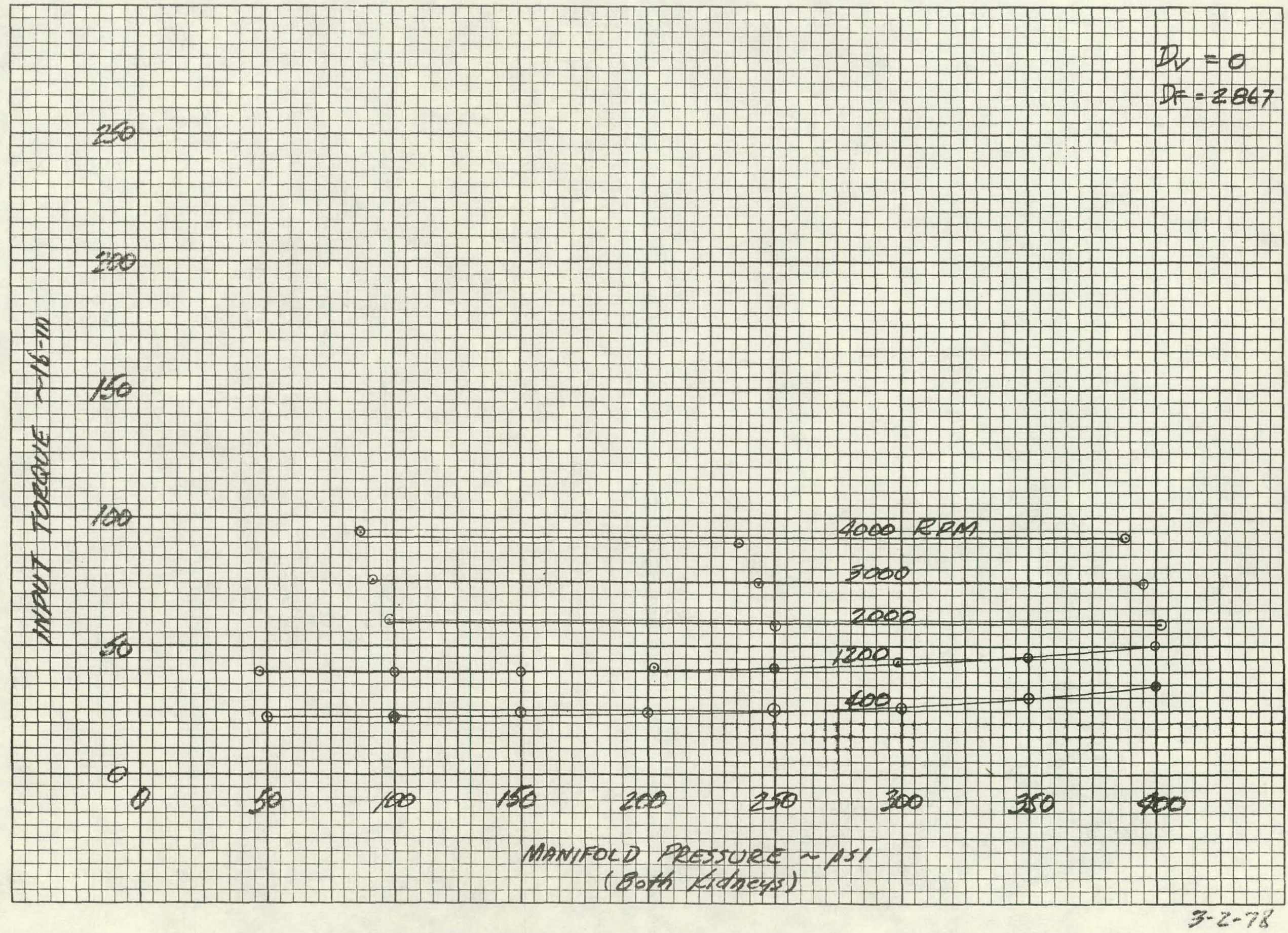




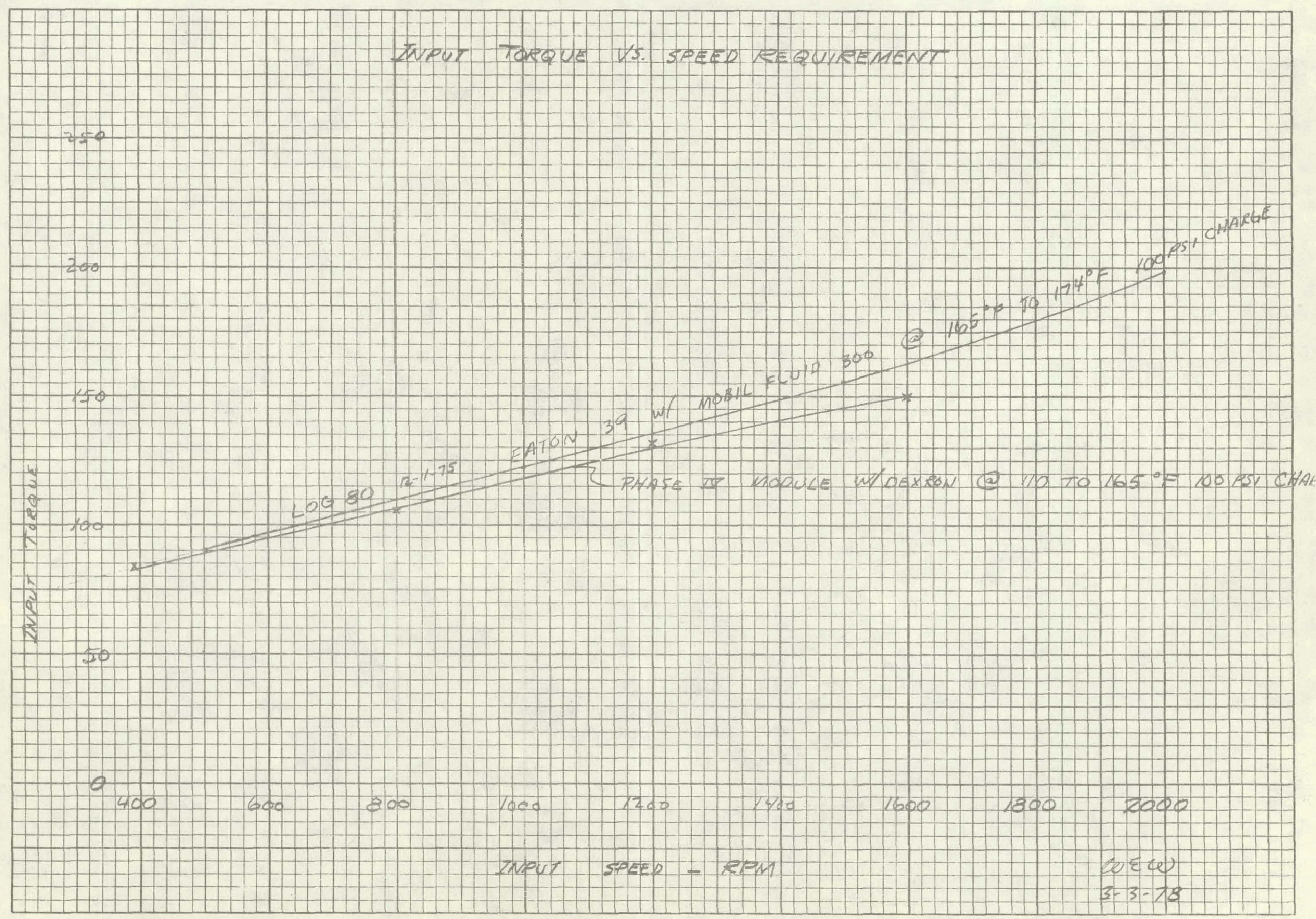




\section{ORSHANSKY TRANSMISSION CORPORATION}

\section{HYDRAULIC MODULE NOISE TESTING PARAMETERS}

Test Conditions for Coaxial Hydrostatic Module for Second Generation Automotive Hydromechanical Transmission

\begin{tabular}{llllllllllllll}
$M$ & $A$ & $X$ & $I$ & $M$ & $U$ & $M$ & $P$ & $O$ & $W$ & $E$ & $R$ \\
\hline
\end{tabular}

Vehicle

Speed

Pump

Motor

\begin{tabular}{|c|c|c|c|c|c|c|}
\hline RPM & TORQUE & DISP. & RPM & TORQUE & DISP. & PR \\
\hline 3500 & 1103 & 1.13 & 1166 & 2500 & 2.88 & 5827 \\
\hline 3500 & 1633 & 2.10 & 2333 & 1976 & 2.88 & 4535 \\
\hline 3500 & 1633 & 3.02 & 3500 & 1329 & 2.88 & 3128 \\
\hline 2334 & 1098 & 2.88 & 3500 & 569 & 1.83 & 2244 \\
\hline 1168 & 922 & 2.88 & 3500 & 211 & .91 & 1881 \\
\hline 60 & 845 & 2.88 & 3500 & 58 & .03 & 1993 \\
\hline
\end{tabular}

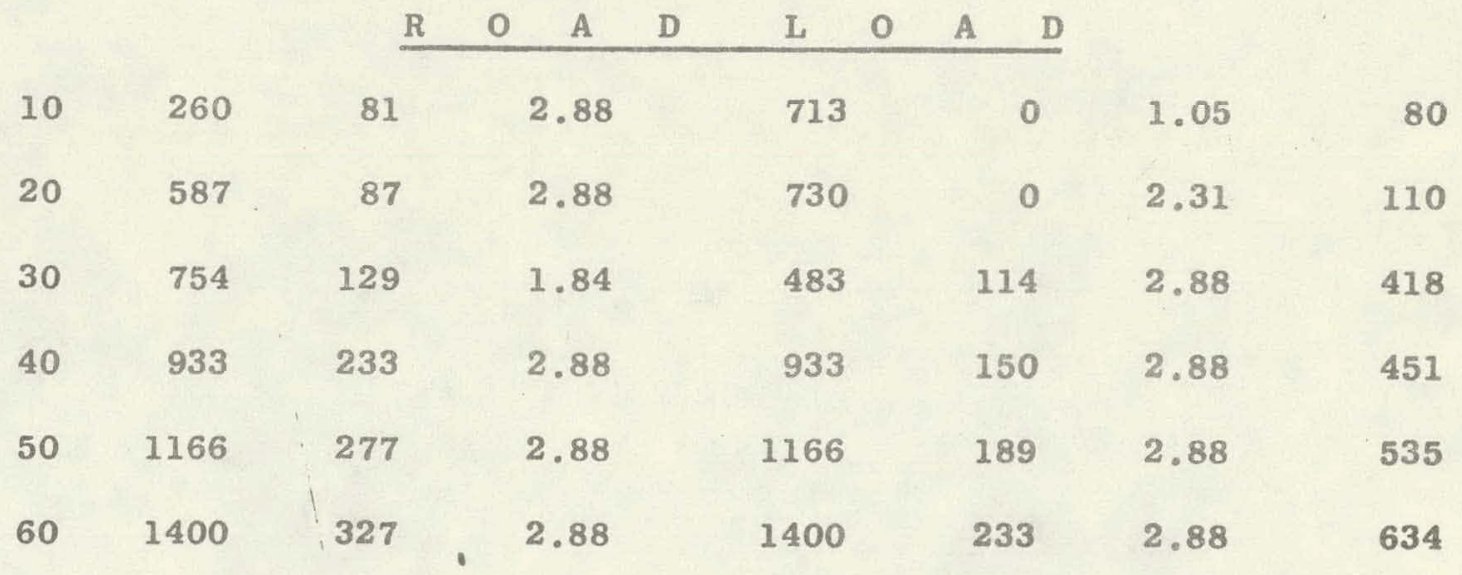




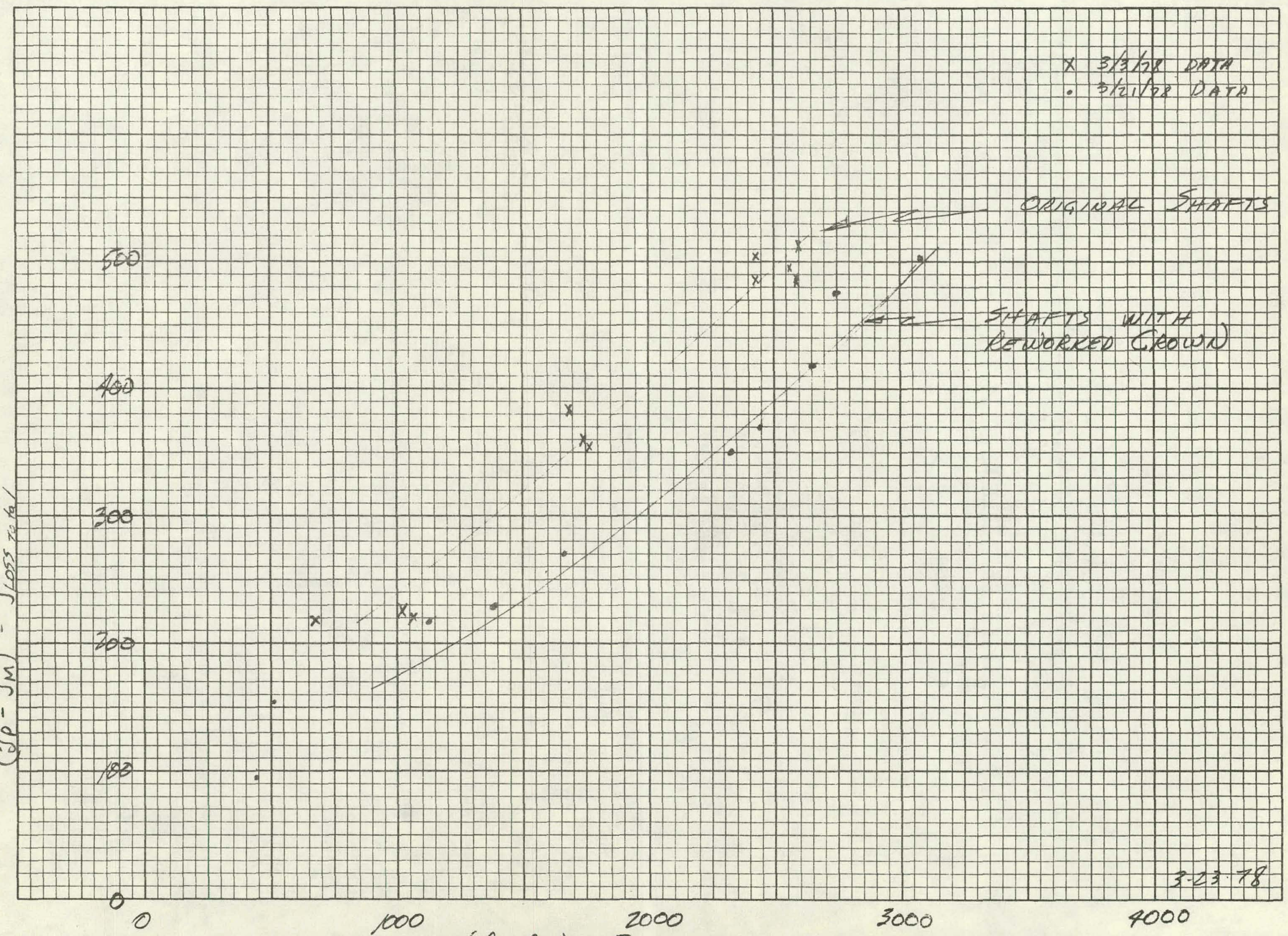




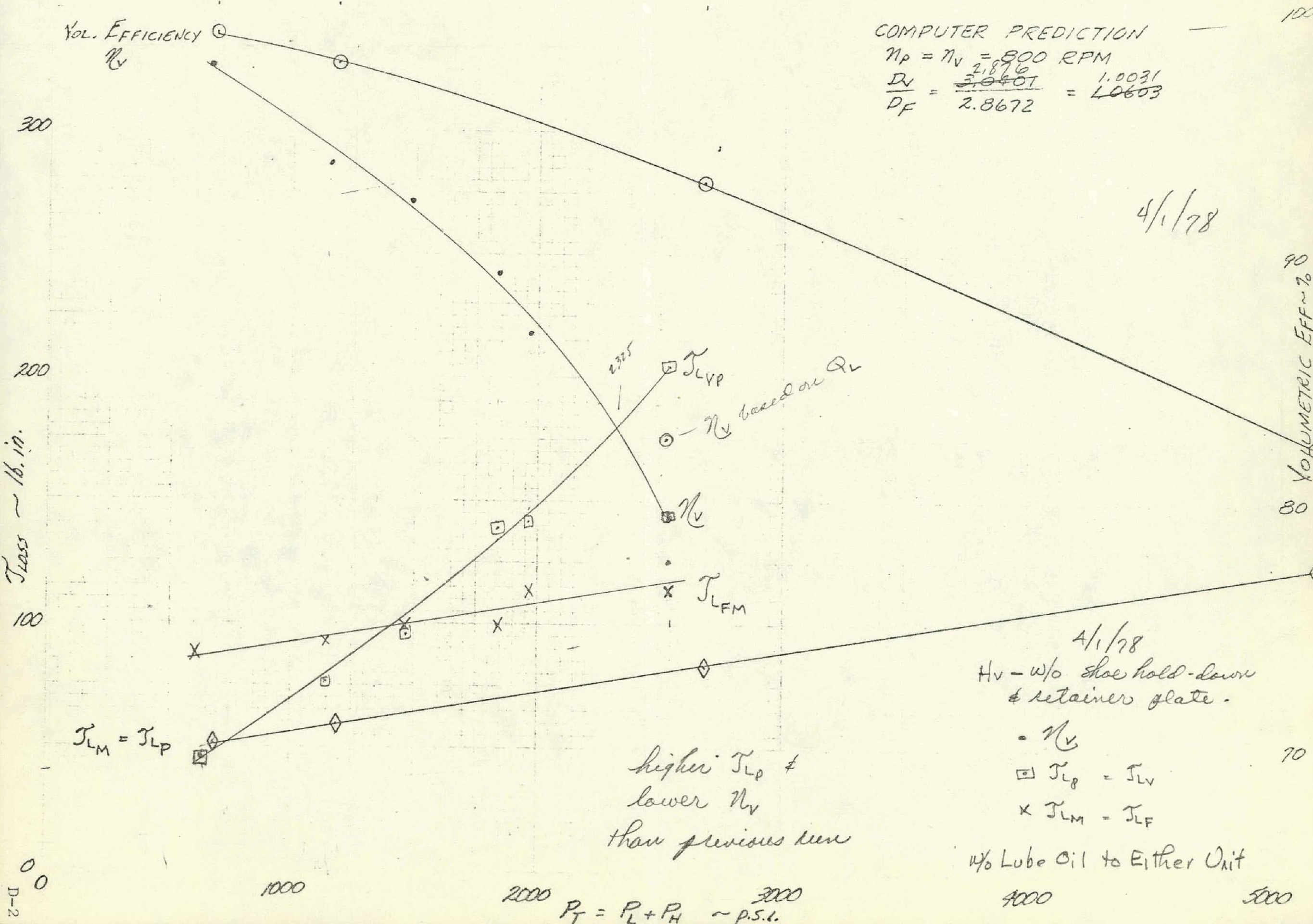




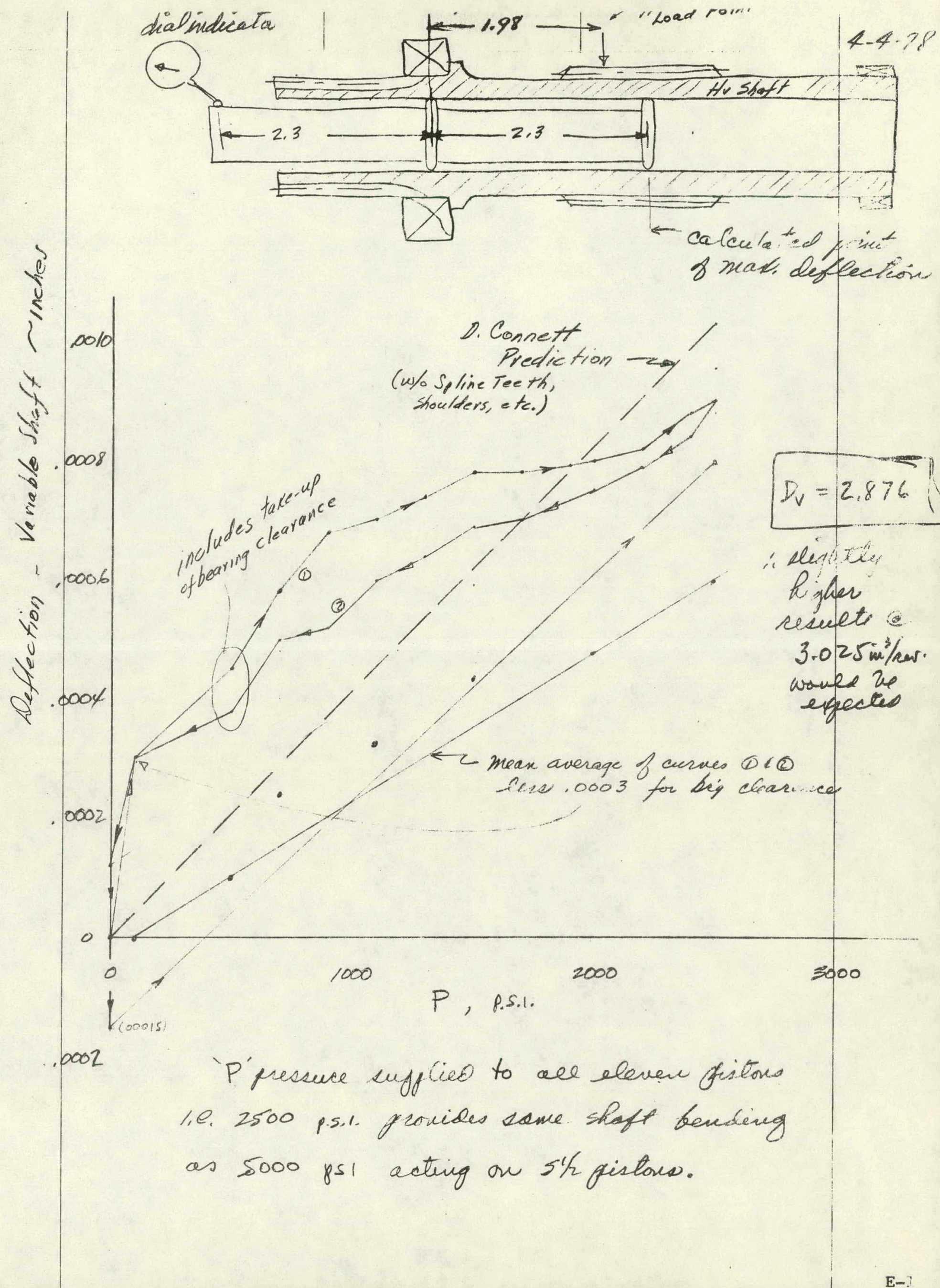


$4-13.78$

MODS \&EPAIRS

VALVE PLATES

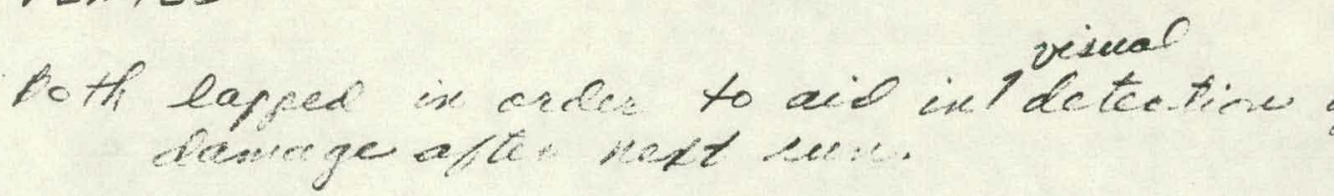

Cre. beorks

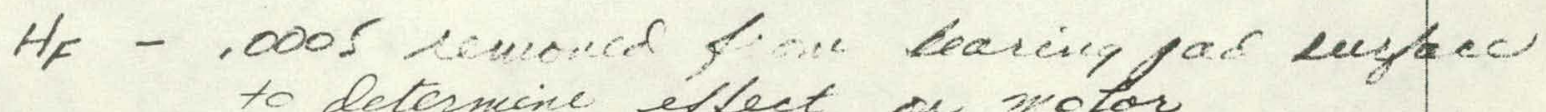
to deternine iffect de motor

HV - Laveing lad serface modgjeid to give $2=$ tapice laved fade
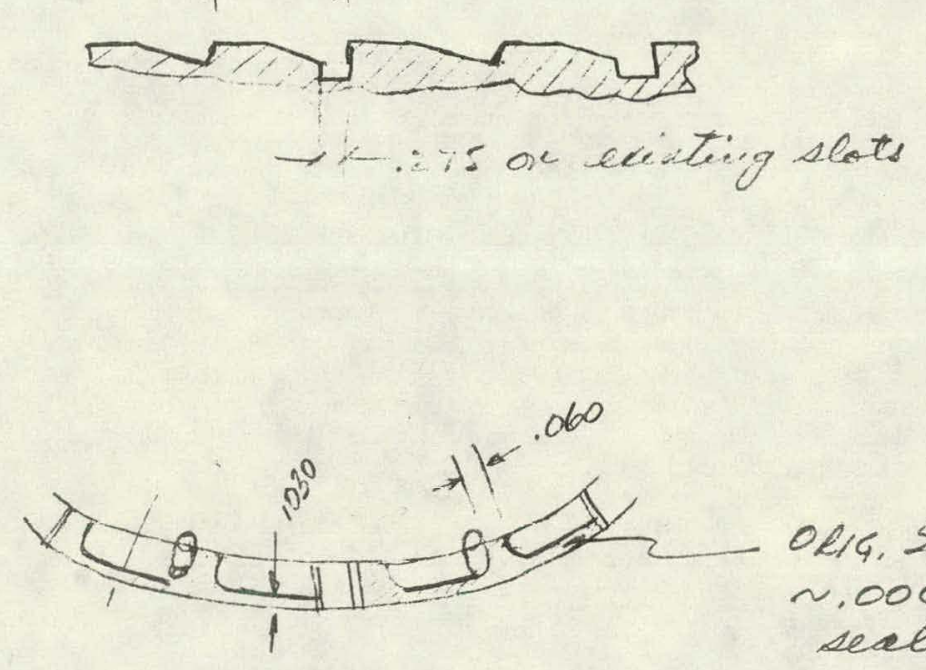

Olla. Surfare $\sim .0005$ beloud secling lands.

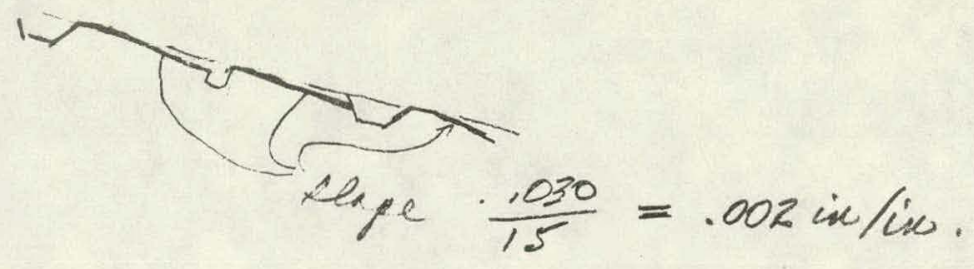

F-1 
$\Delta \quad$

300

200

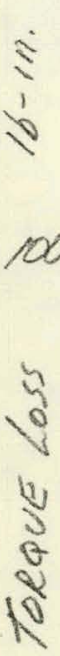

O
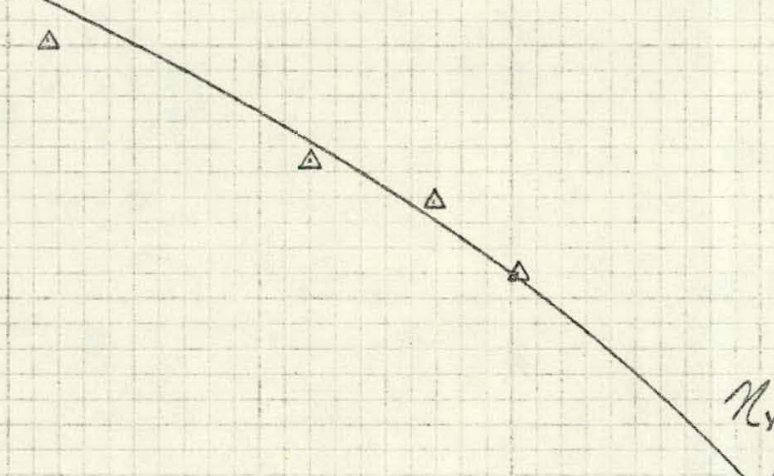

$\Delta$
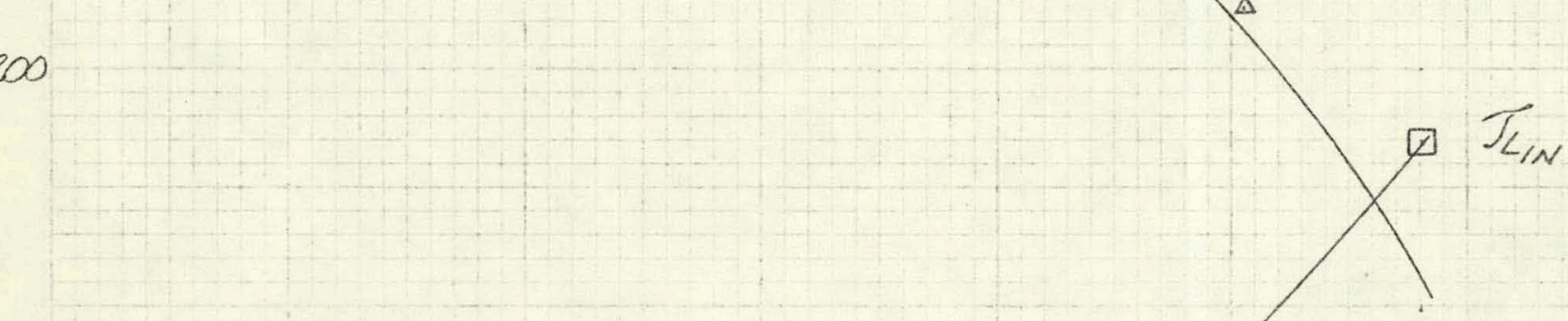

$\frac{D P}{D M}=\frac{2.876}{2.867}=1,00 \%$ 65 sp pings - both daits

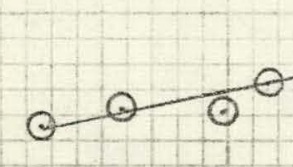

$\odot$ 曰曰

$\triangle$ VOL. EFF.

$0 J_{L_{0}}$

$\square J_{L N} \quad 4-19-18$ 


$$
\begin{aligned}
& A_{v}=P_{\text {ump }} \\
& N_{p}=1165 \\
& \frac{D_{p}}{D_{m}}=\frac{2.876}{2.867}=1003 \\
& 65^{4} \text { Springs - both Units }
\end{aligned}
$$
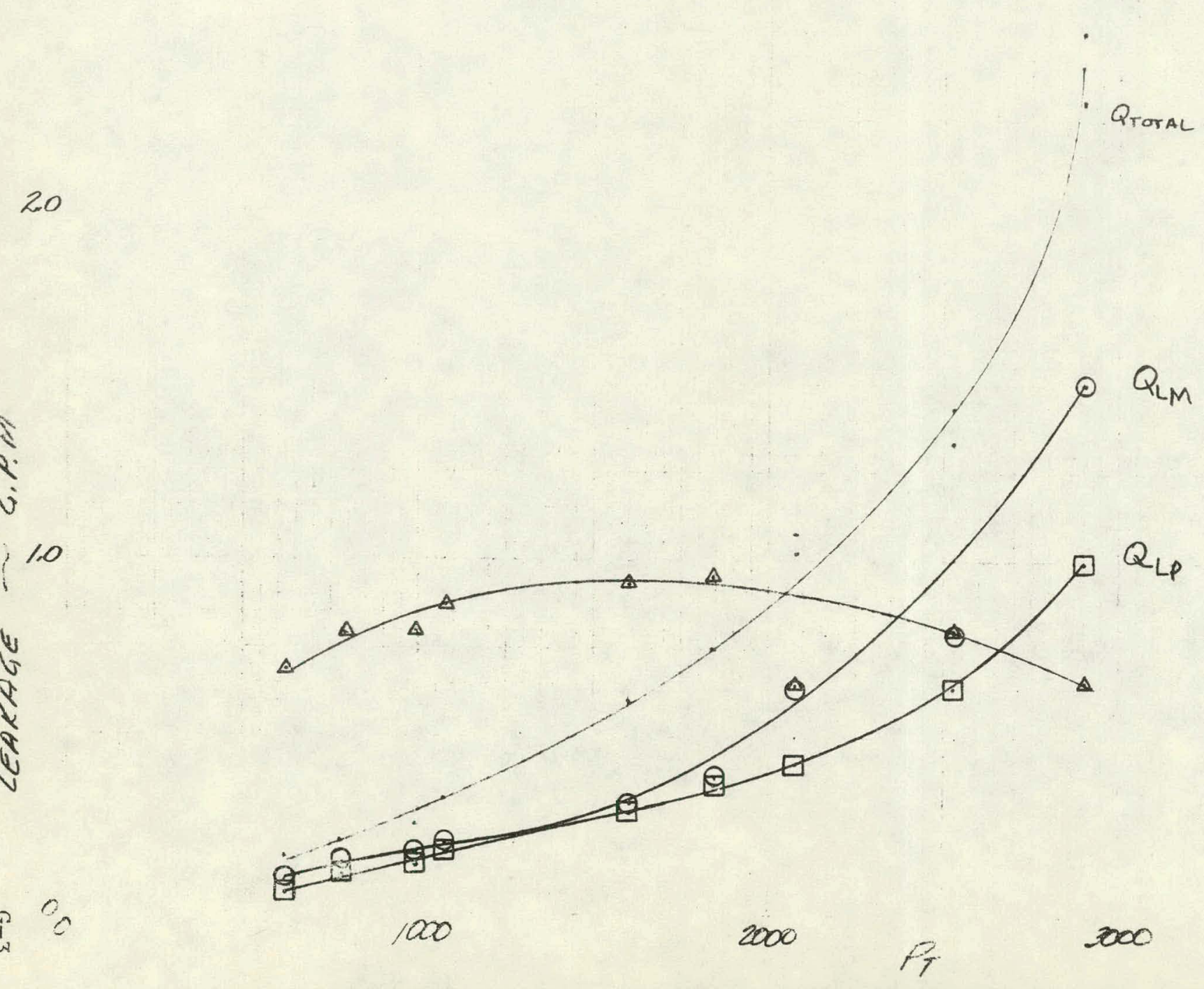


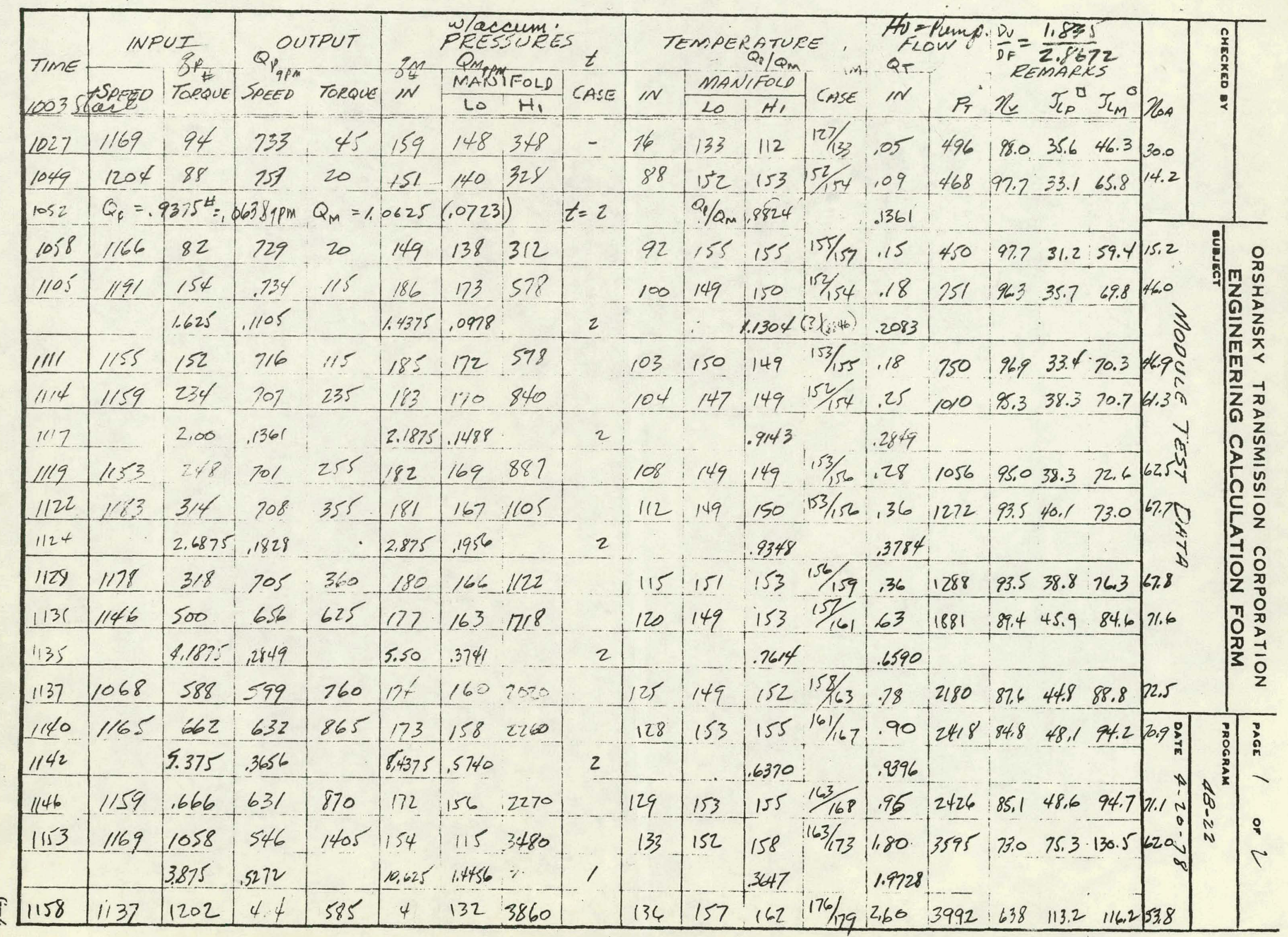




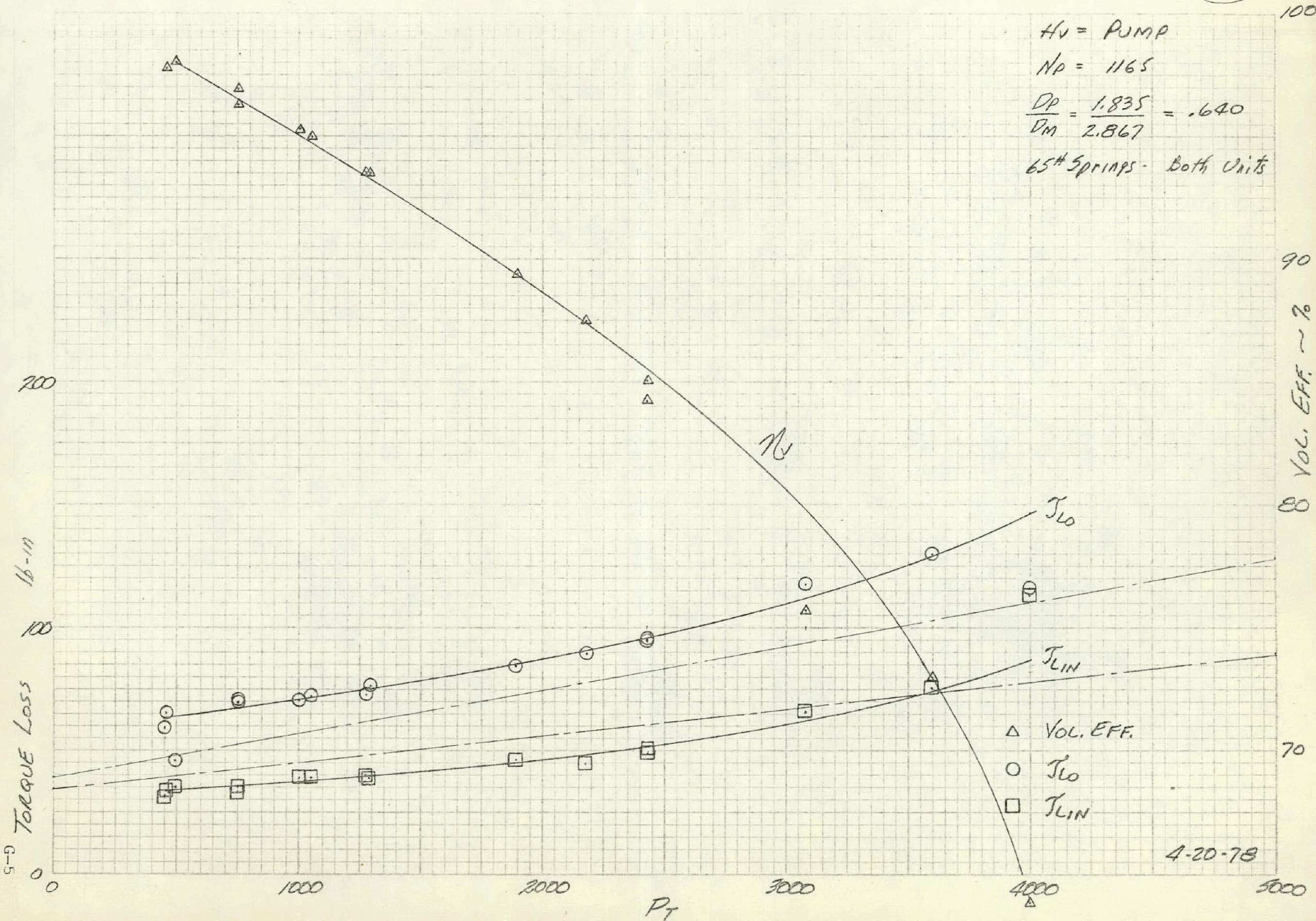


2.5)

$$
\begin{aligned}
& H_{v}=\text { Pump } \\
& N_{p}=1165 \\
& \frac{D_{P}}{D_{m}}=\frac{1.835}{2.867}=.640 \\
& 65^{A} \text { springs - both Units }
\end{aligned}
$$

$$
2
$$

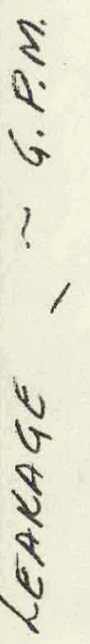

$o_{0}$

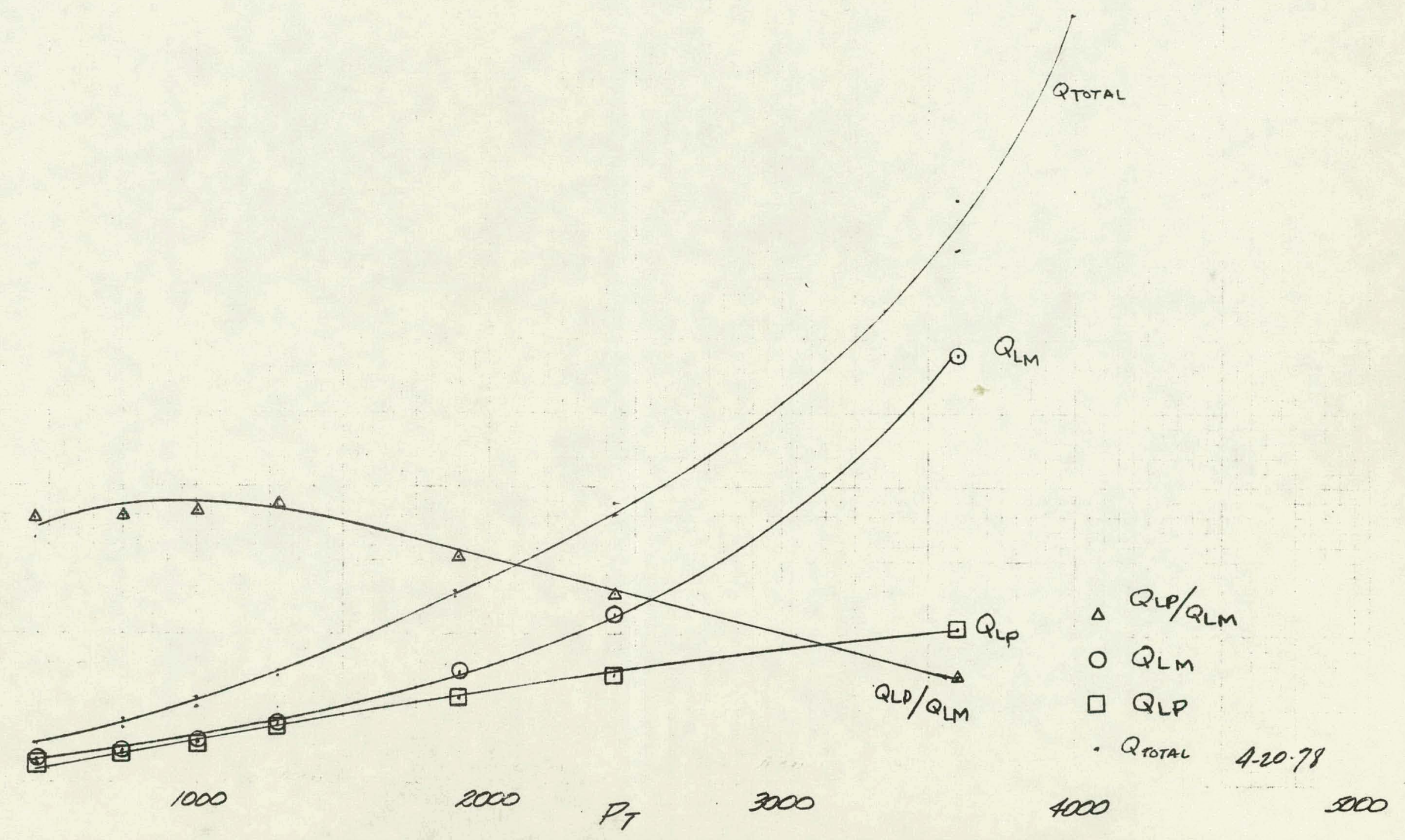




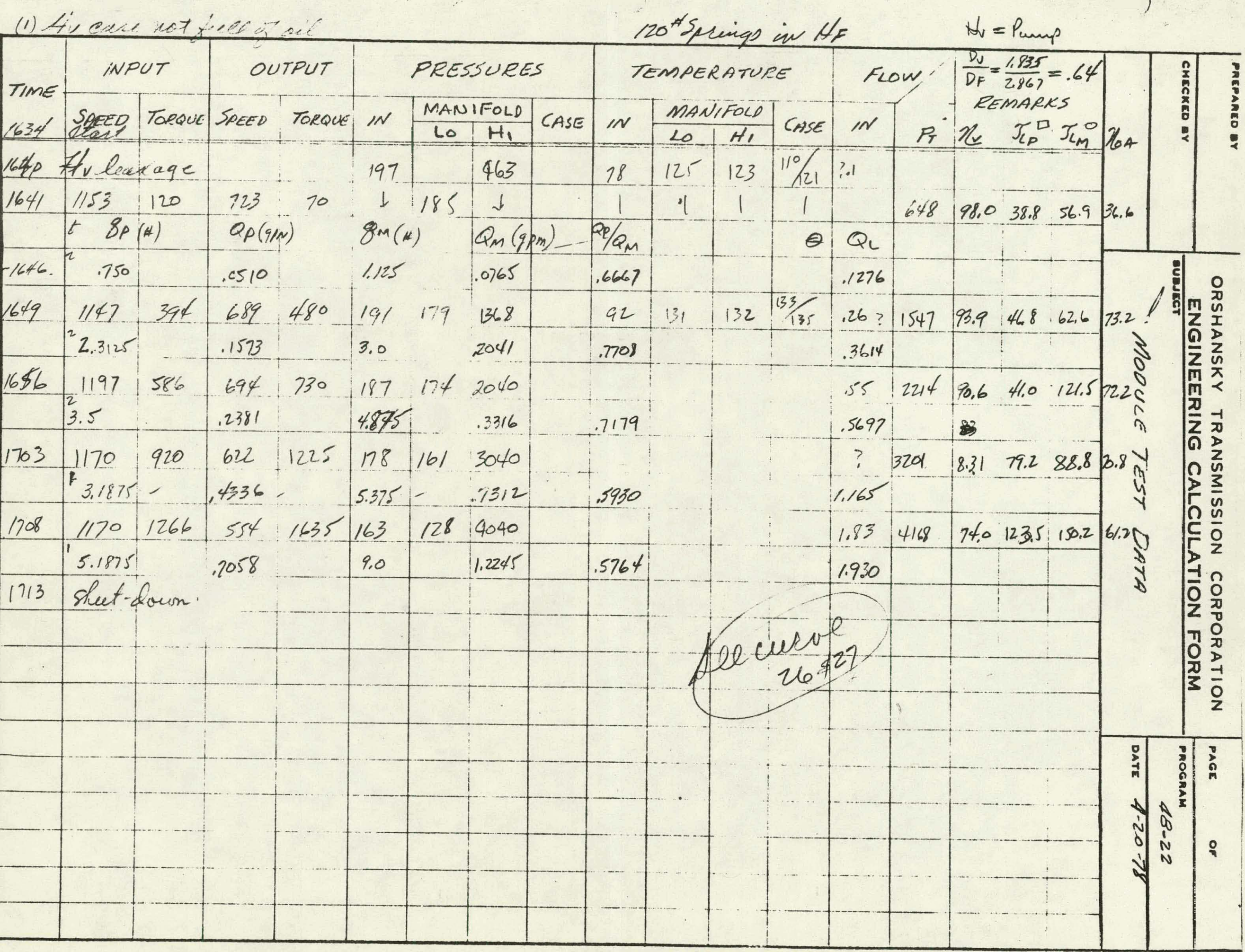




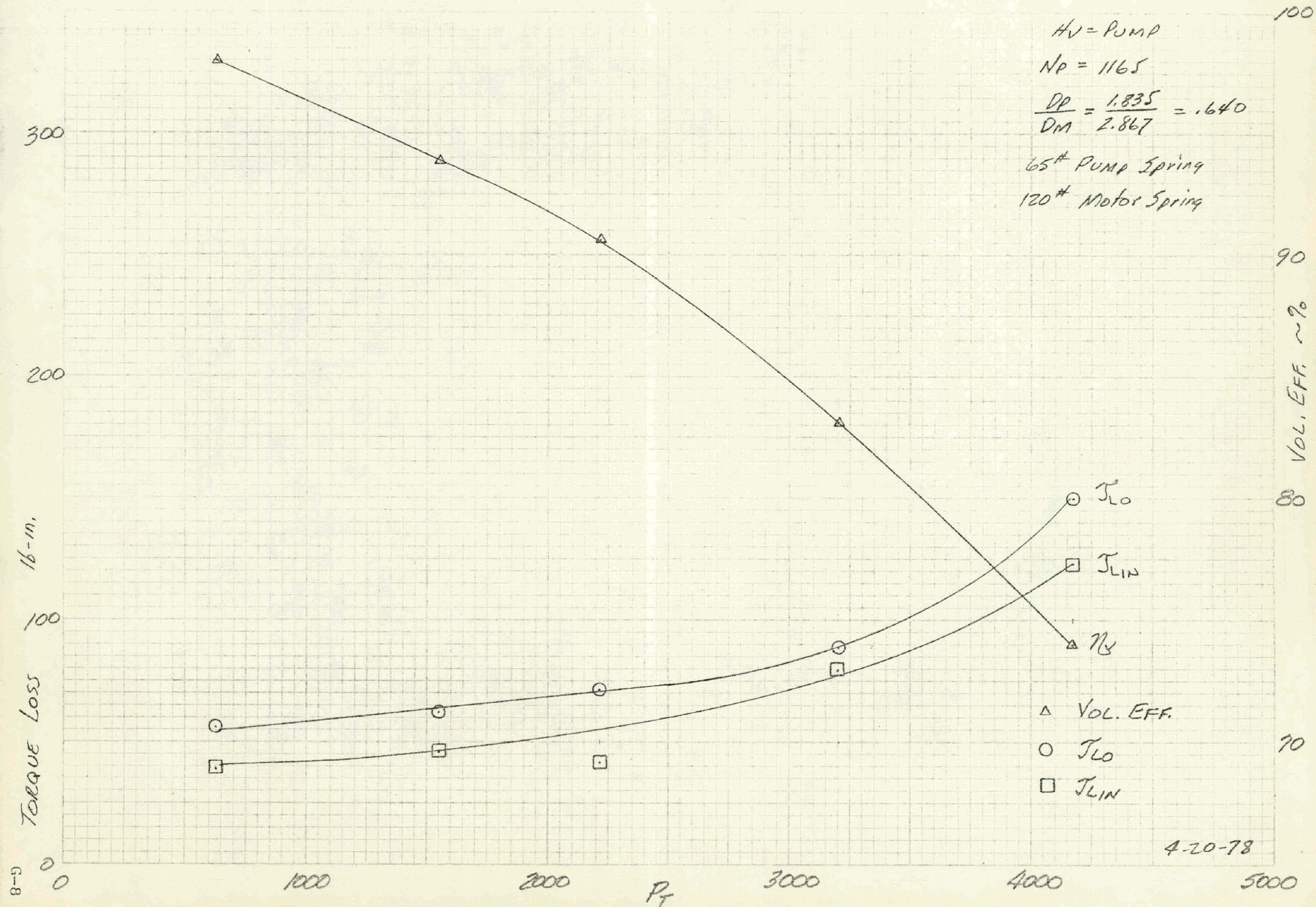




$$
\begin{aligned}
& H_{v}=\text { Puns } \\
& N_{P}=1165 \\
& \frac{D_{P}}{D_{M}}=\frac{1.835}{2.867}=.640 \\
& \text { 65" Pump Spring } \\
& 120^{*} \text { Motor Spring }
\end{aligned}
$$

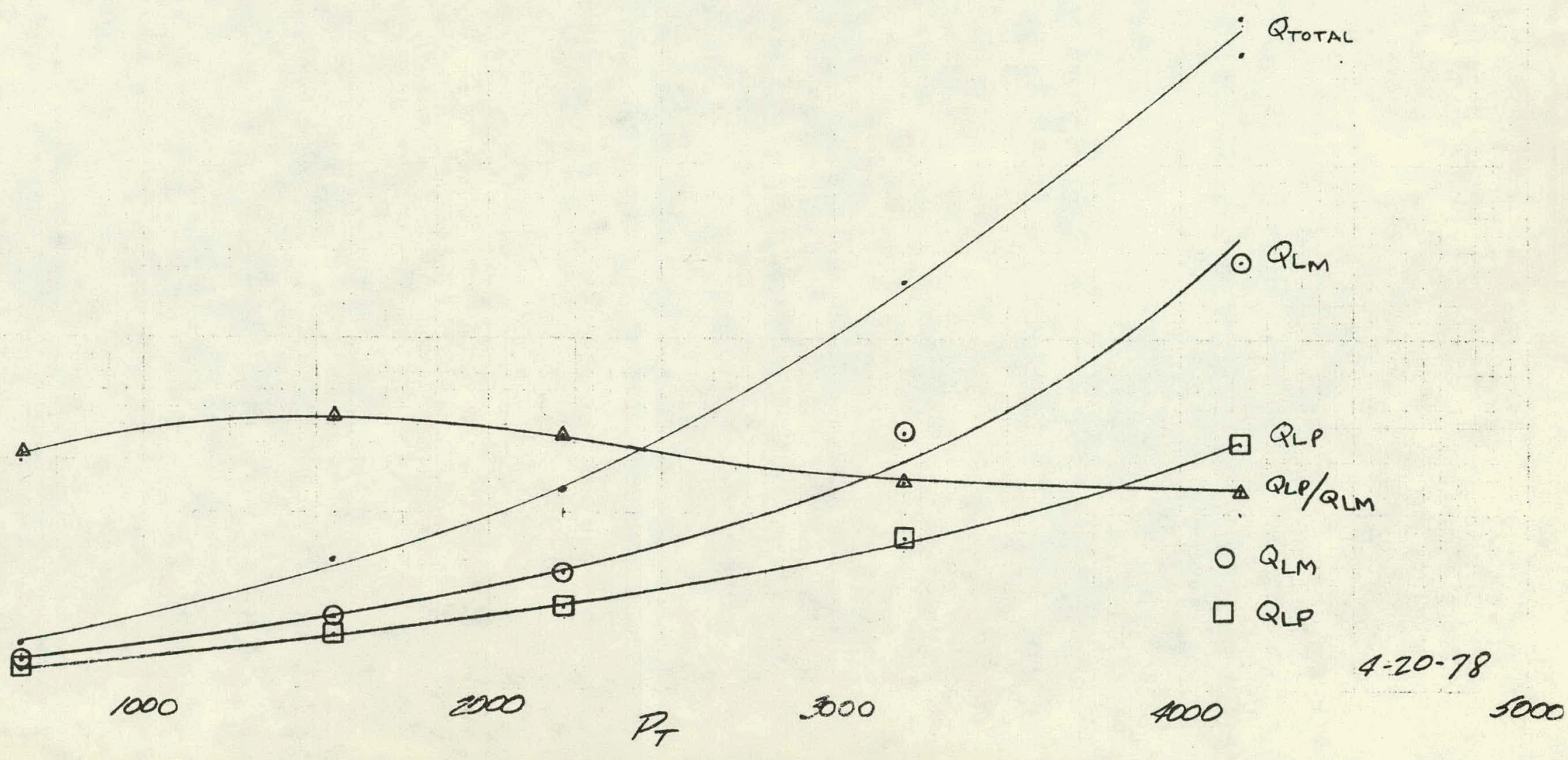


To: $\quad$ Peter Huntley

From: Ken Rudolph

Subject: In-line Hydrostatic Module Development

\section{REVIEW OF TEST STATUS}

Test run on $4 / 19$ was primarily to check individual leakage rates of puup and motor in addition to normal torque loss curves and volumetric efficiency. Torque loss curves include test set-up tare losses.

Curve 22 shows typical torque loss and volumetric efficiency for recent tests. Curve 23 shows excessive leakage at both units, with the fixed motor showing the greatest leakage. Since both units are physically the same, this difference in leakage could be attributed to piston friction. Piston friction 'seats' the pump valve block, and 'unseats' the motor valve block. This could also explain the pump valve plate scoring while motor valve plate is generally unmarked.

Piston friction consists of three types: 1) fl, normal 'sliding' friction, as a function of velocity; 2) f2, piston 'cocking' at B.D.C., as a function of torque, thus pressure; and 3) f3, piston 'sticking' at T.D.C. due to poor bores and/or piston swelling, as a function of pressure. At the present time, sliding friction ( $f l$ ) is assumed to be minimal. To test for $f 2$ and $f 3$, the pump displacement was reduced from 2.876 to 1.835 CIPR. For the same pump speed, and same system pressure, this modification was expected to produce the following changes:

\section{Expected Change}

Variable Disp. Pump

Axial load on housings and bolts Shaft bending loads

Windage loss

Piston friction:

$$
\begin{aligned}
& f l \text { - sliding } \\
& f 2 \text { - cocking at B.D.C. } \\
& f 3 \text { - sticking at T.D.C. }
\end{aligned}
$$

None

Reduced (1)

None

Reduced (3)

Reduced (4)

Reduced (4)

Reduced (5)
Fixed

Disp. Motor

None

None

Reduced (2)

Reduced (2)

None

None

Reduced (6) 
To: Peter Huntley

From: Ken Rudolph

Subject:In-line Hydrostatic Module Development

\section{NOTES:}

(1) Calculations and lab tests show this not to be a problem at full displacement and pressure, therefore affect should be minimal.

(2) Torque loss improvements in motor will be a result of these two items.

(3) Assumed to have only minor affect on pump torque loss, and could be estimated from motor torque loss improvements as noted in (2).

(4) If either of these has been the problem, the shorter pump piston stroke should result in significant torque loss reduction.

(5) Reduced pump leakage could be due to lower piston velocity and possibly more stable cylinder block/valve plate interface.

(6) Reduced motor leakage would be a result of lower piston velocity. Lower piston velocity could also affect piston cocking (f2) and sticking ( $f 3$ ), and thus provide more stable cylinder block/valve plate interface.

Test results at reduced pump displacement are shown on curves 24 and 25 . Comparison of these with previous curves shows minor improvements in motor torque loss and significant pump torque loss reduction. A portion of the motor torque loss improvement attributed to lower piston velocity was also present in the pump unit, as noted in Note 3 , and is only a minor affect as assumed. This leads to conclusion that piston cocking at B.D.C. and/or piston sticking at T.D.C. has been the prime contributor to inefficiencies.

Comparison of curves 23 and 25 shows reduced leakage in both units, with the most significant change occurring in the pump. If the remarks in Note 5 are a valid explanation of this result, then the motor leakage should be reduced, if heavier springs were installed in the motor. Curves 22 thru 25 were for tests run with $65 \#$ springs in each unit, although original design was for 120:H springs.

Curves 26 and 27 show results with the 120 \# springs installed only in the motor. This not only reduced motor leakage, as expected, but also reduced motor torque losses. 
To: $\quad$ Peter Huntley

From: Ken Rudolph

Subject: In-lire Hydrostatic Module Development

These tests lead to the conclusion that piston friction must ke reduced. For the moment it is still assumed that rormal sliding friction, $f l$, is not the primary problem. This leaves piston cocking, f2, and piston sticking, $f 3$, to be resolved.

FUTURE TEST PLANS

The next test will be made with the cylinder barrel bores relieved at the bottom of the bores, (T.D.C.). This will reduce the possibility of bad bores as the cause of high torque losses and leakage, particularly at higher pressures. The results will show only in the motor, since the pump will still be at partial displacement.

During the past two tests, there has been no valve plate damage, therefore if the next test does show reduced motor leakage, the pump displacement. will be returned to $2.876 \mathrm{CIPR}$ without disassembly, and tested for pump leakage.

If piston bore reliefs show little or no improvement in performance, the conclusion will be that piston cocking at B.D.C. is the problem. If this proves to be true, the solution may well require some re-design and new hardware. The Sundstrand Series 18 pistons are being used in our units with a piston engagement at B.D.C. of approximately 0.78 inches, for an $\mathrm{L} / \mathrm{D}$ ratio of $1.2 \mathrm{k}$. In the Sundstrand unit, 0.9 .8 inches piston engagement for an $\mathrm{L} / \mathrm{D}$ ratio of 1.52 exists at B.D.C. This is brought about by the fact that we have slightly longer piston strokes (.021 in fixed unit and .063 max. in variable unit), and that we have atout .17 less piston entrance into cylinder bore at T.D.C., due to our hold-down mechanism. Our longer piston stroke combined with a larger pitch radius ( 1.49 vs. 1.196 ) to the pistons results in more cylinder block upsetting moments due to centrifugal force on pistons. This may have been a prime contributor to our early failures at higher. speeds and low pressures.

KR: Iw

Enclosures aches

22 Hine
27 miskedp

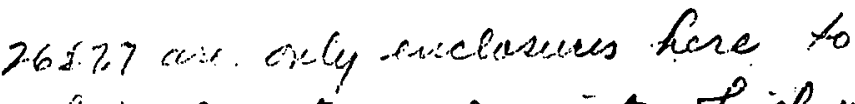

sibew Congutio pred gaints which were int on arig. ceevies. 


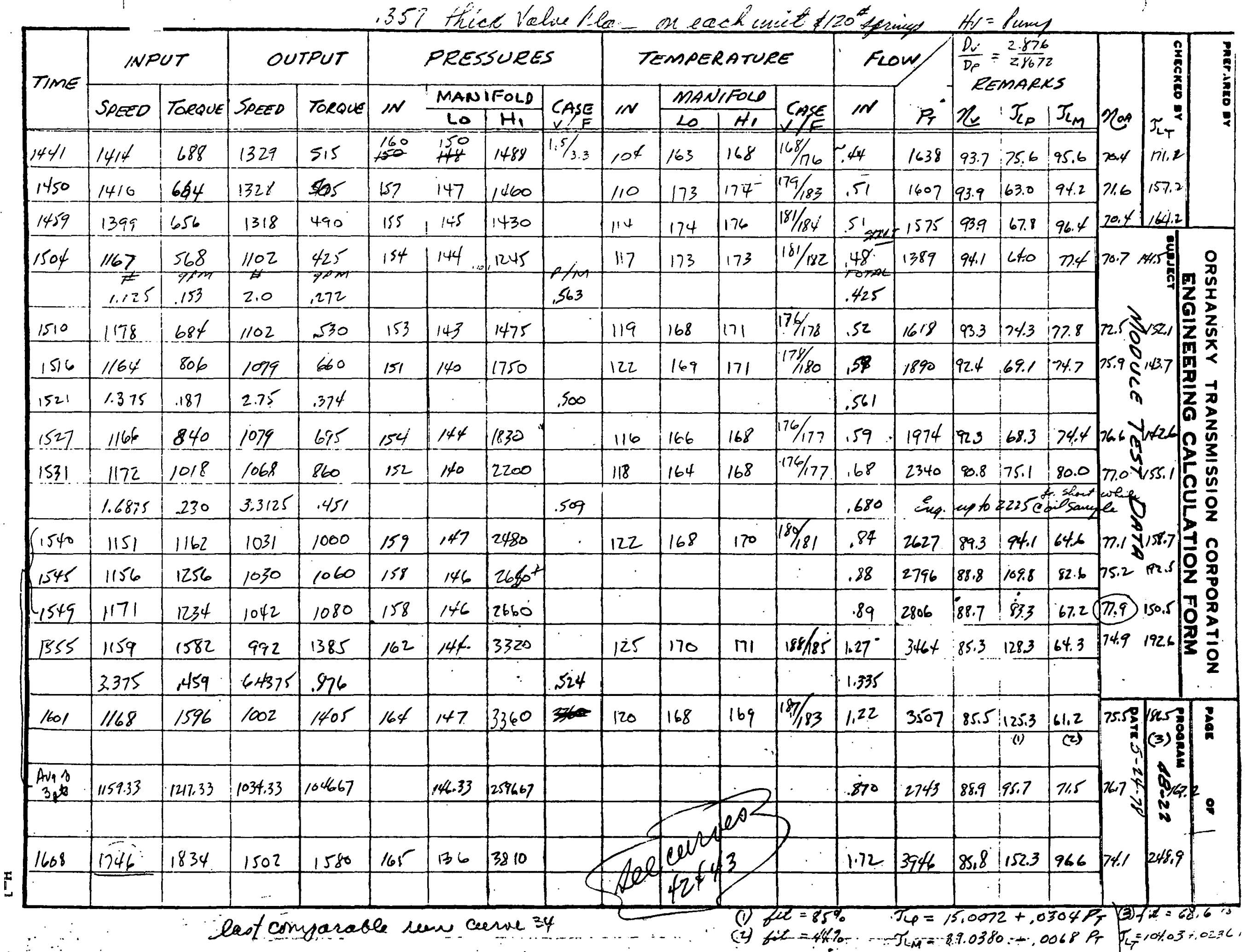




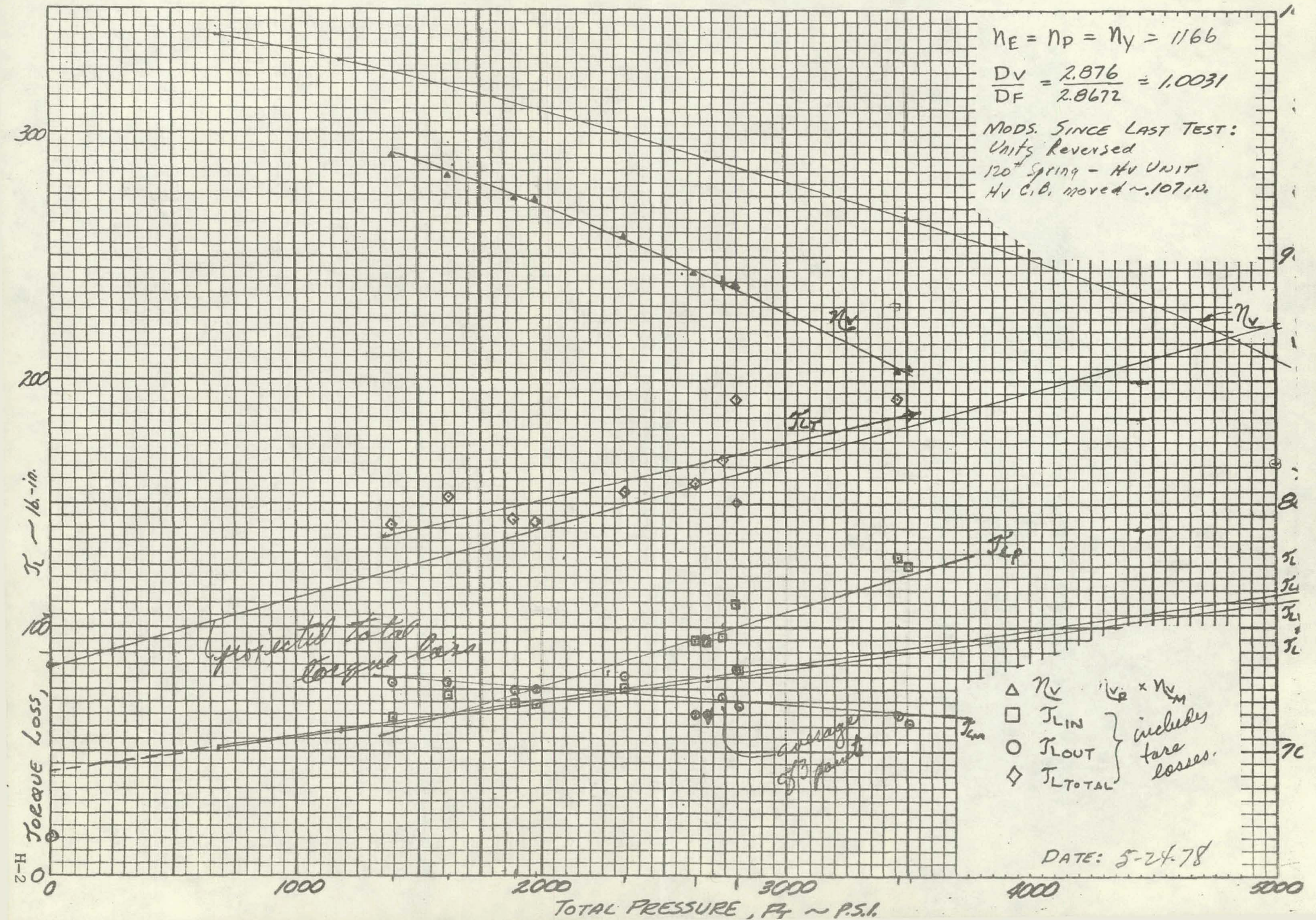




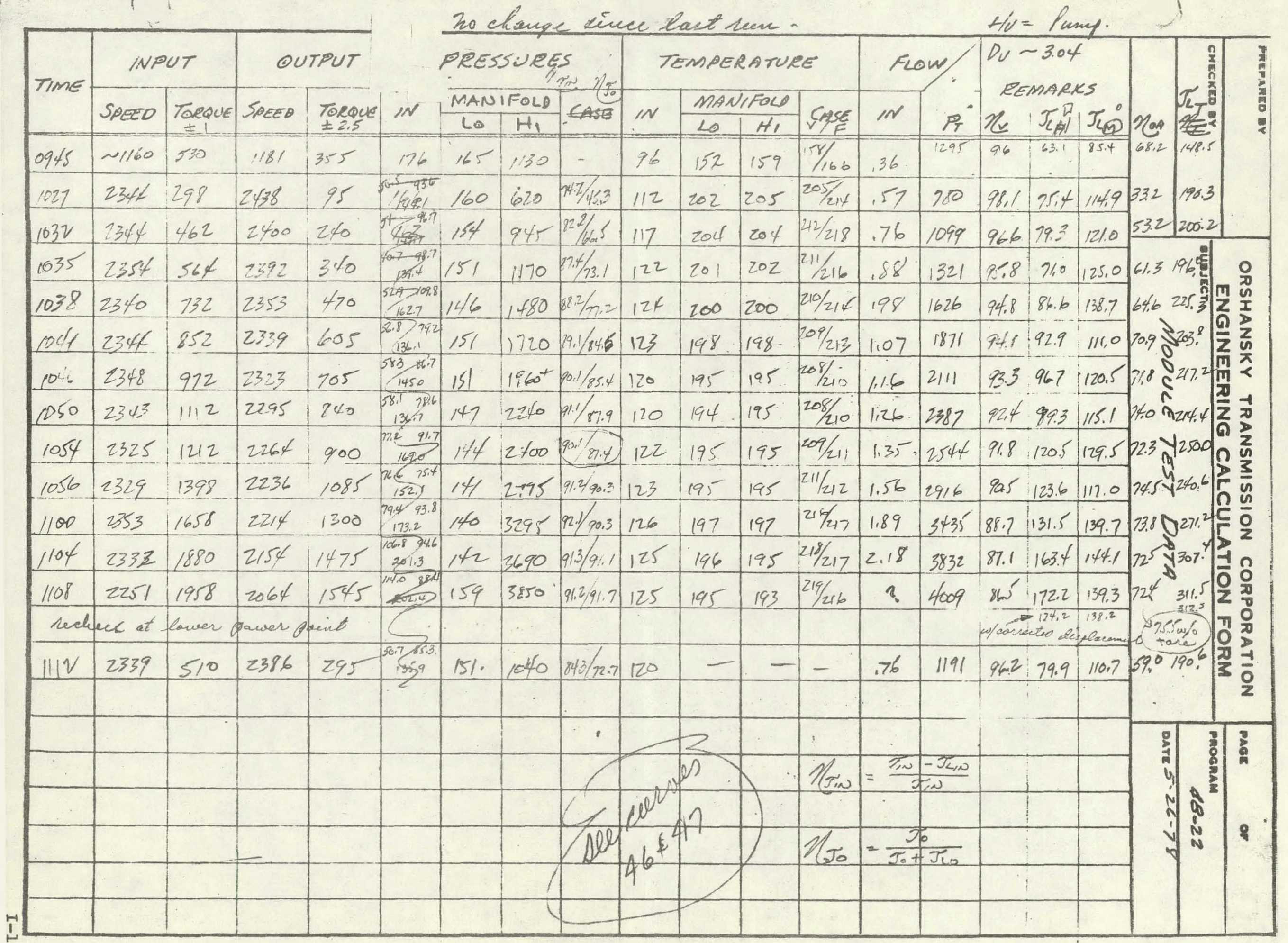




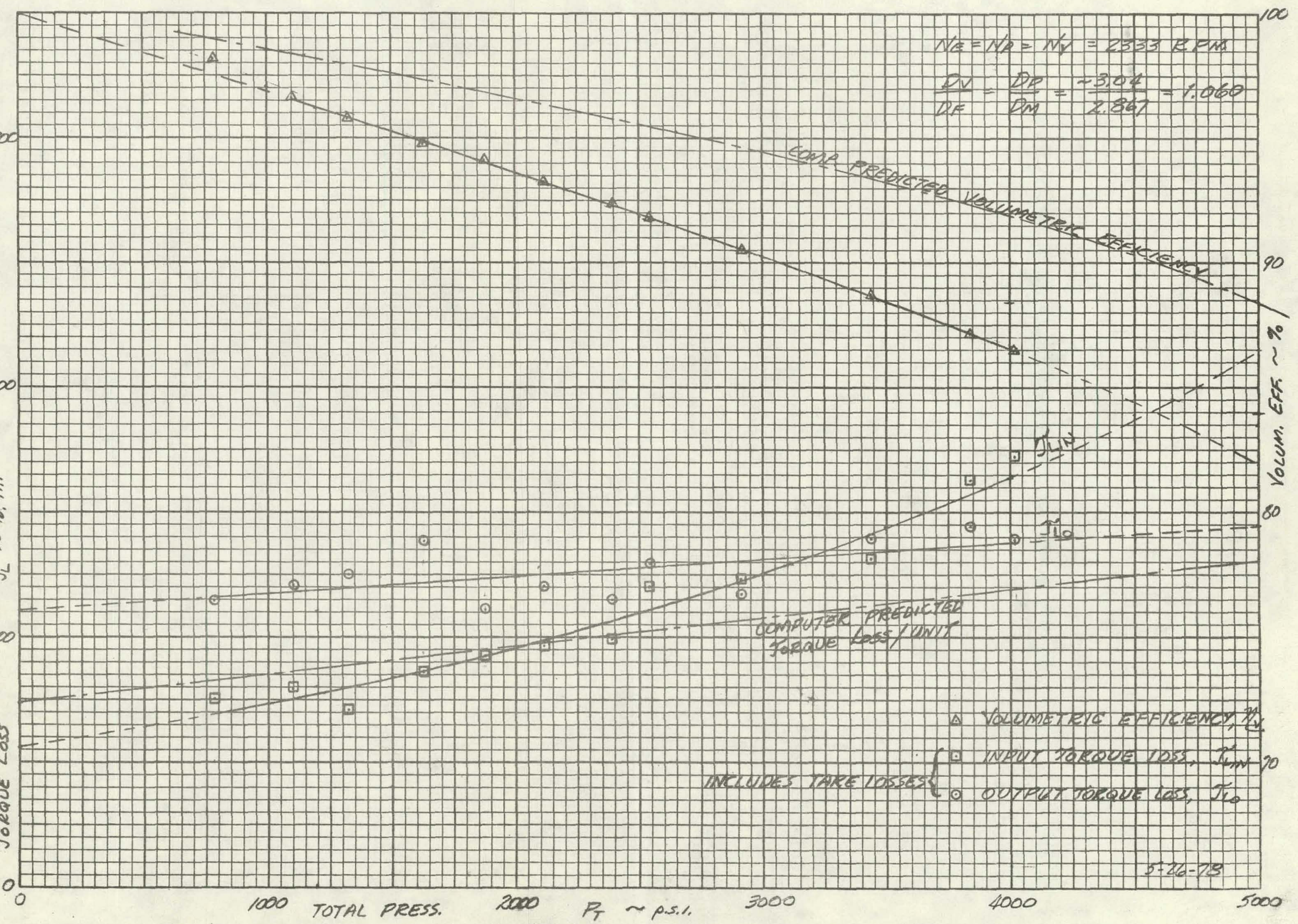


1,75

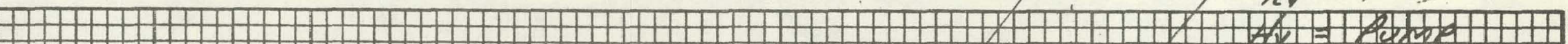

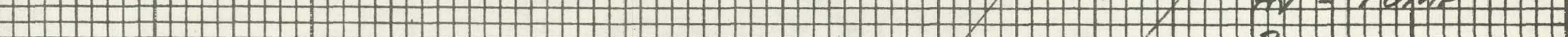
H. 100000

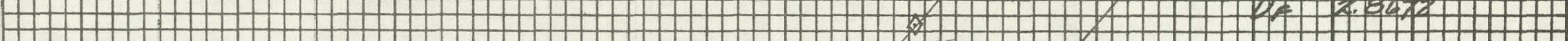

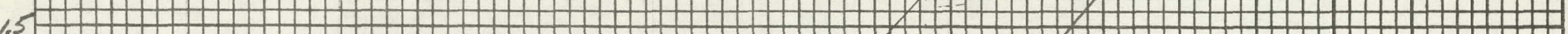

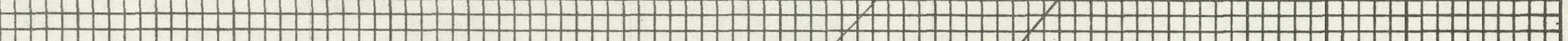

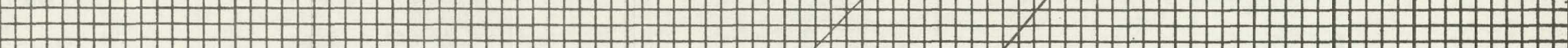

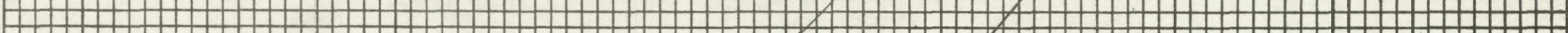

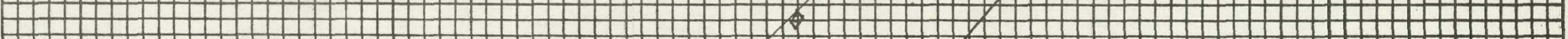

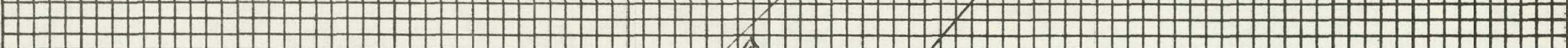

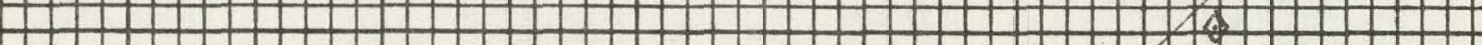

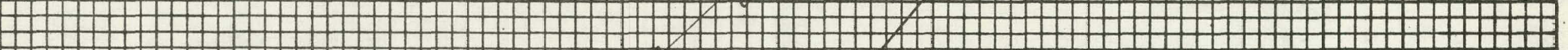

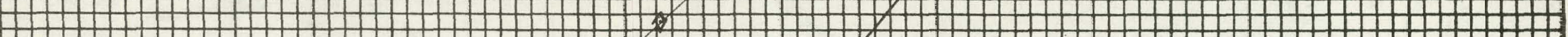
(1)

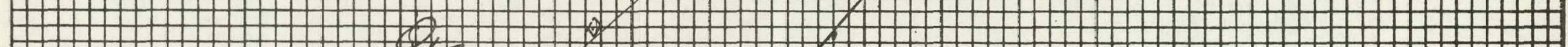

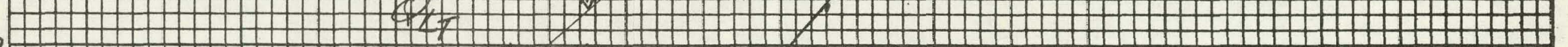

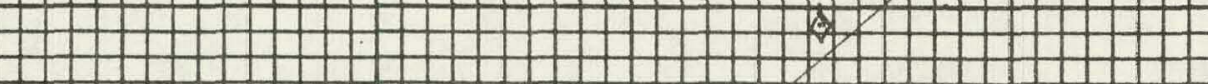

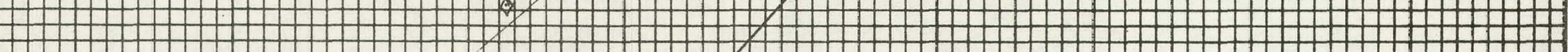

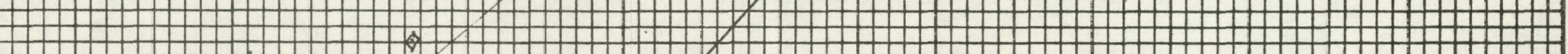

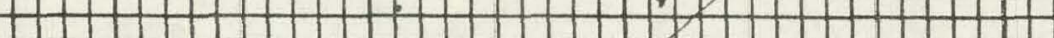

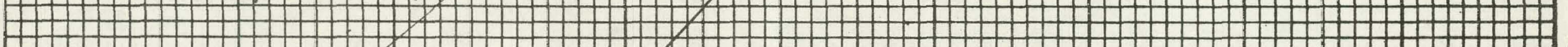

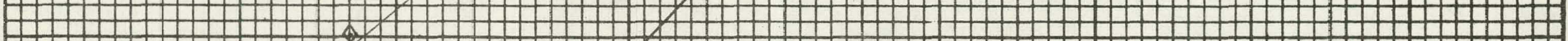

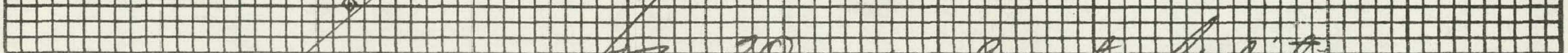

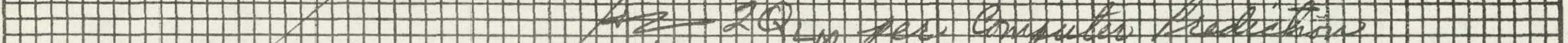

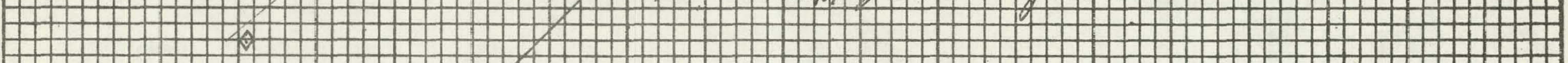

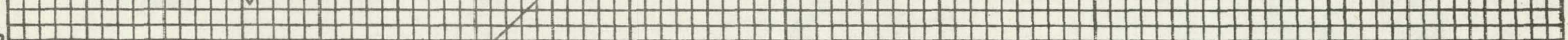

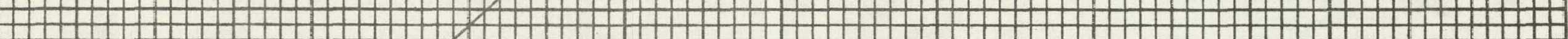

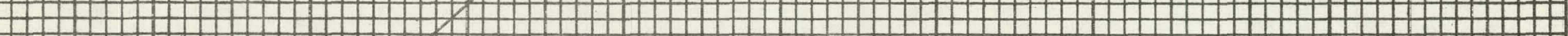

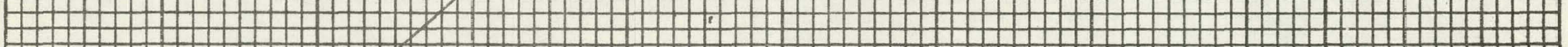

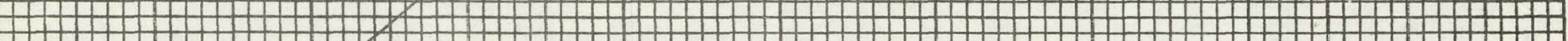

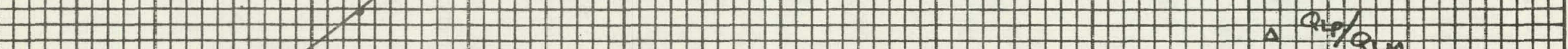

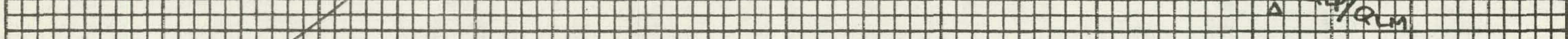

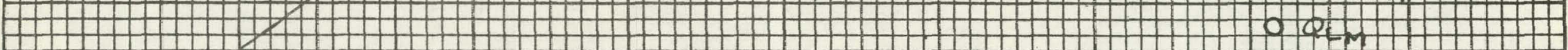

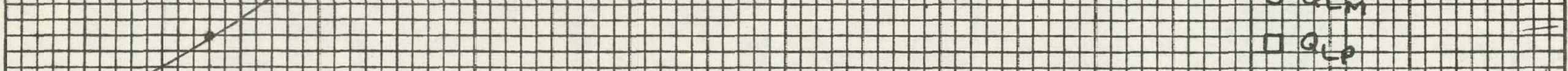

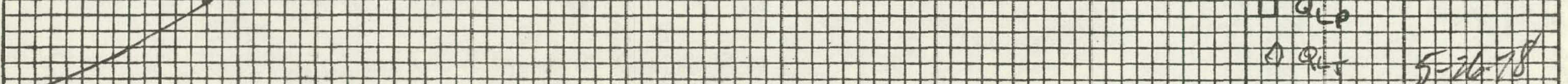
心 0 1000 2000 2000 4000 


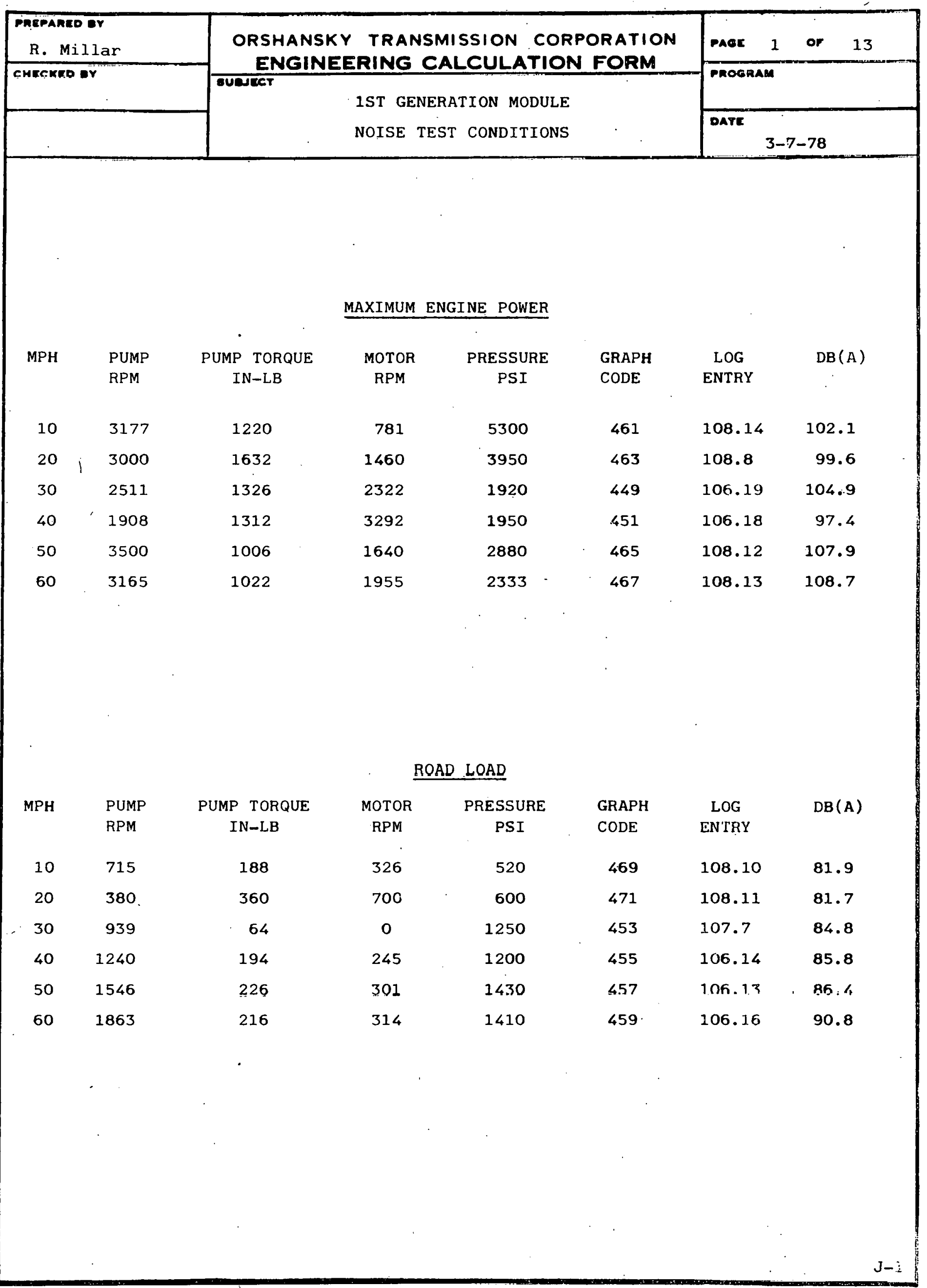




\begin{tabular}{|c|c|c|}
\hline $\begin{array}{l}\text { PaEpanco ur } \\
\text { R. Millar }\end{array}$ & \multirow{2}{*}{$\begin{array}{c}\text { ORSHANSKY TRANSMISSION CORPORATION } \\
\text { ENGINEERING CALCULATION FORM }\end{array}$} & PAGK 2. Or 13 \\
\hline CHECKED or & & PAOCRAM \\
\hline & $\begin{array}{l}\text { 1ST GENERATION MODULE } \\
10 \text { MPH - FULL POWER }\end{array}$ & DATE $3-7-78$ \\
\hline
\end{tabular}

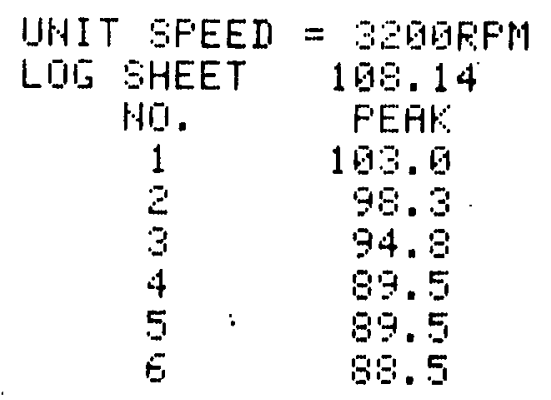

FFE IUENC'

1410.0 460.0

940.9

1156.0

1986.0

415.6

\begin{tabular}{|c|c|c|c|c|c|}
\hline $\begin{array}{l}\text { DLTHWE EHHI } \\
\text { EEHTER } \\
\text { FREOUEHLY }\end{array}$ & $\begin{array}{l}\text { WEASUEEI } \\
\text { SDUUII } \\
\text { FFESSURE }\end{array}$ & $\begin{array}{c}\text { FUOINA } \\
\text { DOFEEETIOHA }\end{array}$ & $\begin{array}{l}\text { POWEF: } \\
\text { LEVEL }\end{array}$ & $\begin{array}{l}\text { A WEIGHT } \\
\text { EORFELT I DH }\end{array}$ & $\begin{array}{l}\text { COREEETED } \\
\text { - LEVEL }\end{array}$ \\
\hline 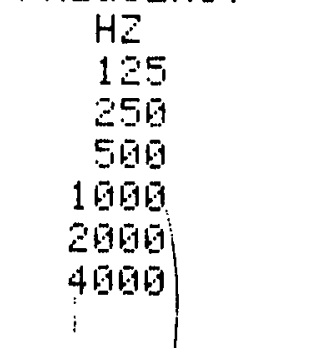 & $\begin{array}{r}\text { IE } \\
0.0 \\
0.9 \\
98.7 \\
163.8 \\
89.5 \\
9.0\end{array}$ & $\begin{array}{l}\text { IIE } \\
-2.5 \\
-3.6 \\
-2.5 \\
-2.5 \\
-2.0 \\
-0.5 \\
\text { IIB }\end{array}$ & $\begin{array}{r}I 18 \\
-2.5 \\
-3.9 \\
96.2 \\
191.5 \\
37.5 \\
-0.5 \\
102.5\end{array}$ & $\begin{array}{c}\text { DB } \\
-16.0 \\
-8.5 \\
-3.0 \\
0.0 \\
1.0 \\
1.0 \\
\text { DEH }\end{array}$ & $\begin{array}{r}\text { IIE } \\
-18.5 \\
-11.5 \\
93.2 \\
101.3 \\
88.5 \\
0.5 \\
=102.1\end{array}$ \\
\hline
\end{tabular}




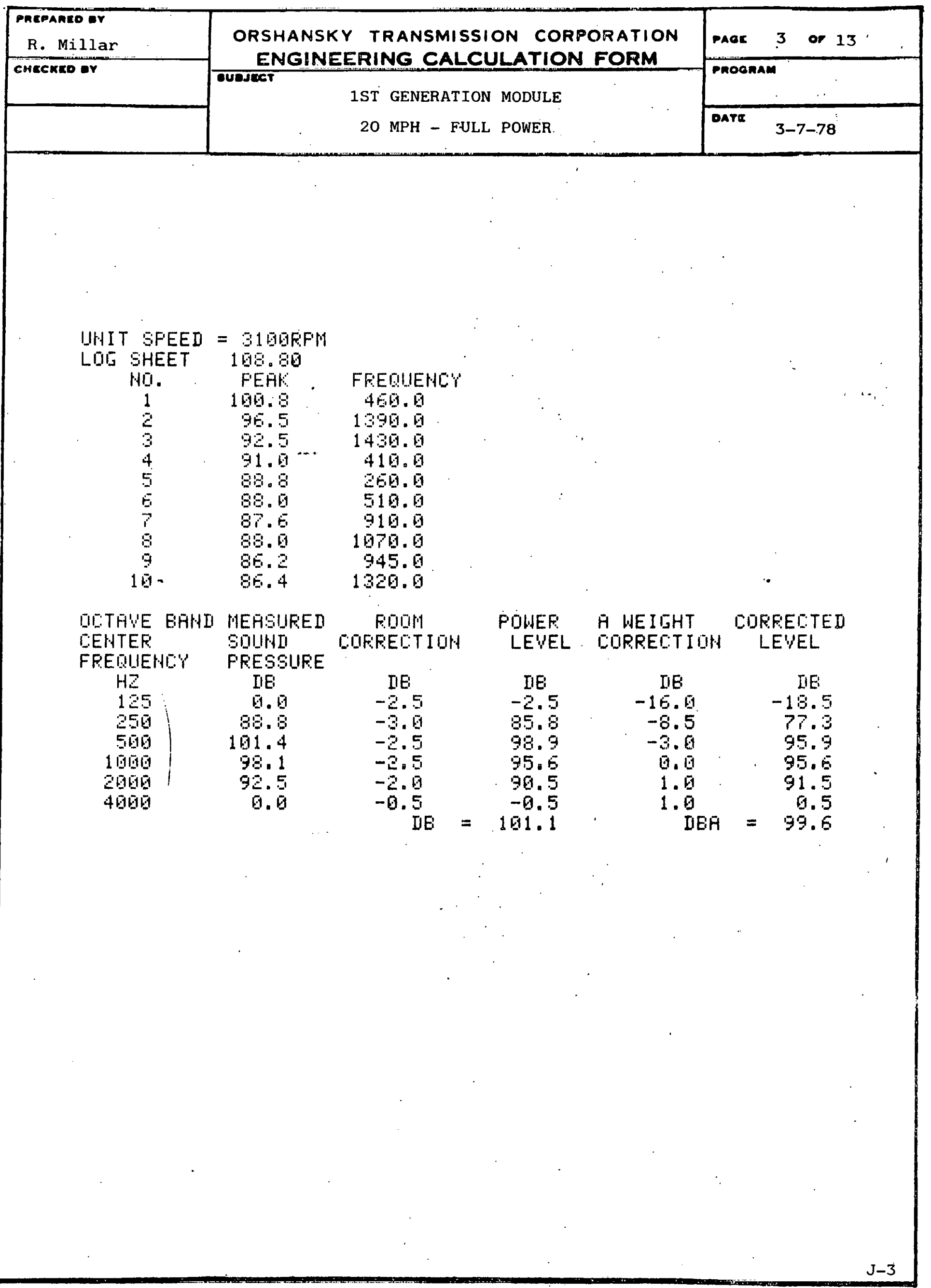




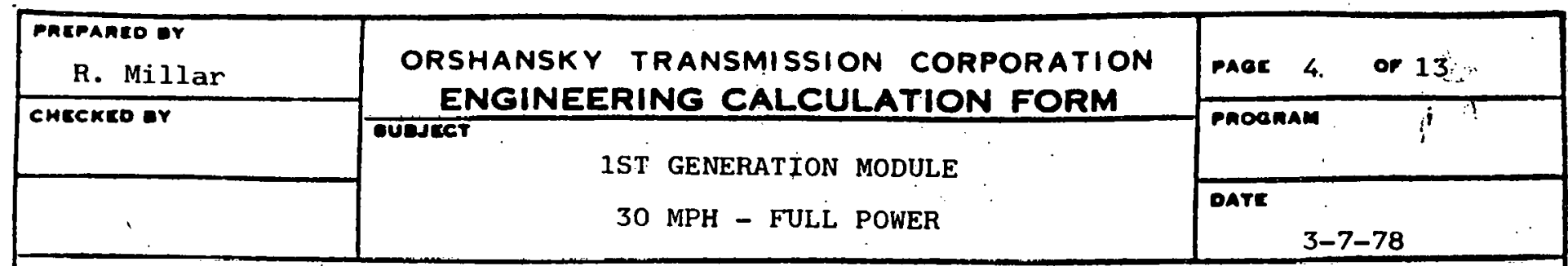

UHIT SFEEI = 250GFFW

LOE SHEET 1 GE.19

H1. FEAK

1 194.

$2 \quad 99.5 \therefore$

$3 \quad 98.6$

$4 \quad 96.0$

$5 \quad 95.6$

E. $\quad 95.2$

$7 \quad 94.4$

$9 \quad 94.6$

$9 \quad 93.8$

$16 \quad 93.5$

1192.6

$12 \quad 91.5$
FFEEDIJEHC'Y

3日日.

75.6

1380.0

1510.0

1940.9

1746.6

1576.9

1586.6

760.0

1460.6

1130.0

356.6

DE:THUE EAHI MEFBIIREI

CENTEF

FEERIJEHIYY SDINHII

$\mathrm{HZ}$

125

26

5010

1006

20160

4606

FFESGIJFE

Ron DOGFEETT I UH

FOIVEF:

A WEILHT

LEVEL

COFREC:T I DH.

CORFELTED

IIE

IIE:

91.5

104.4

103.6

101.7

6. 6

\begin{tabular}{rr} 
IE & \multicolumn{1}{c}{ IIB } \\
-2.5 & -2.5 \\
-3.0 & 88.5 \\
-2.5 & 101.9 \\
-2.5 & 190.5 \\
-2.01 & 99.7 \\
-0.5 & -0.5 \\
IIE = & 105.6
\end{tabular}

IDE

$-16.9$

$-8.5$

$-3.6$

0.0

1.0

1.0

LEVEL

JEA $=104.9$ 


\begin{tabular}{|c|c|c|}
\hline $\begin{array}{l}\text { Repaco or } \\
\text { R. Millar }\end{array}$ & $\begin{array}{l}\text { ORSHANSKY TRANSMISSION CORPORATION } \\
\text { ENGINEERING CALCULATION FORM }\end{array}$ & paar 5 . \\
\hline CWECKEO OV & OUESCT & Pnoonam \\
\hline( & 40 MPH - FULL POWER & DATE $3-7-78$ \\
\hline
\end{tabular}

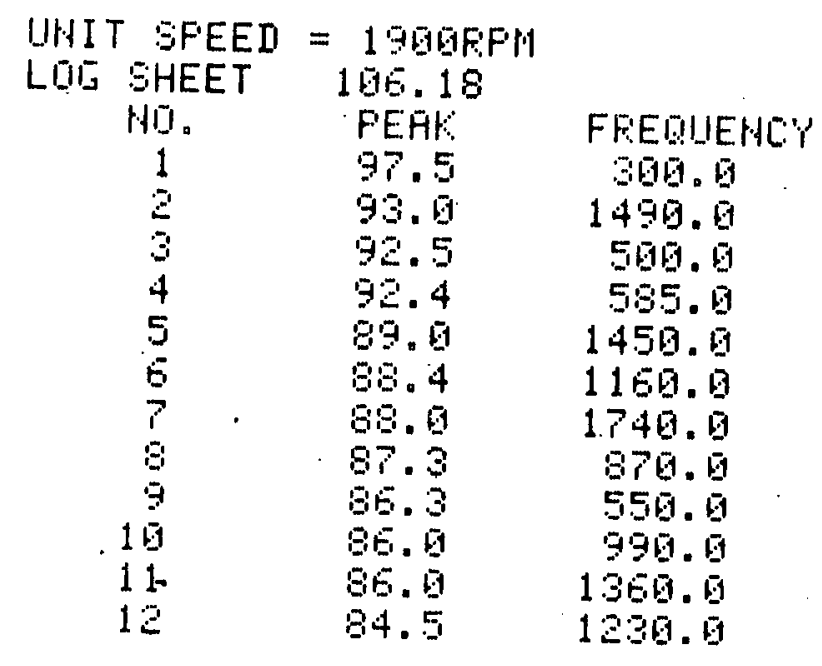

\begin{tabular}{|c|c|c|c|c|c|}
\hline $\begin{array}{l}\text { DU:THUE EAHII } \\
\text { EEHTEE } \\
\text { FREDUEHLY }\end{array}$ & $\begin{array}{l}\text { MEHSUF:EI } \\
\text { SDUIHI } \\
\text { FFESSGUFE }\end{array}$ & $\begin{array}{c}\text { FUIOUN } \\
\text { GOREEETIDHA }\end{array}$ & $\begin{array}{l}\text { FOWEF } \\
\text { LEVEL }\end{array}$ & $\begin{array}{l}\text { A WE I GHT } \\
\text { CORRECTIOOS }\end{array}$ & $\begin{array}{l}\text { OOFEFEETED } \\
\text { LEVEL }\end{array}$ \\
\hline $\begin{array}{l}H 2 \\
125 \\
250 \\
506 \\
10106 \\
2060 \\
4060\end{array}$ & $\begin{array}{r}\text { IIE } \\
9.0 \\
97.5 \\
96.0 \\
93.6 \\
95.3 \\
.0 .0\end{array}$ & $\begin{array}{c}\text { IIE } \\
-2.5 \\
-3.5 \\
-2.5 \\
-2.5 \\
-2.9 \\
-0.5 \\
\text { IIE }\end{array}$ & $\begin{array}{l}\text { II } \\
-2.5 \\
94.5 \\
93.5 \\
91.1 \\
93.3 \\
-0.5 \\
99.3\end{array}$ & $\begin{array}{c}\text { IIE } \\
-16.0 \\
-8.5 \\
-3.0 \\
0.0 \\
1.0 \\
1.0 \\
D B A\end{array}$ & $\begin{array}{c}\text { IE } \\
-18.5 \\
8 E .9 \\
99.5 \\
91.1 \\
94.3 \\
0.5 \\
=97.4\end{array}$ \\
\hline
\end{tabular}




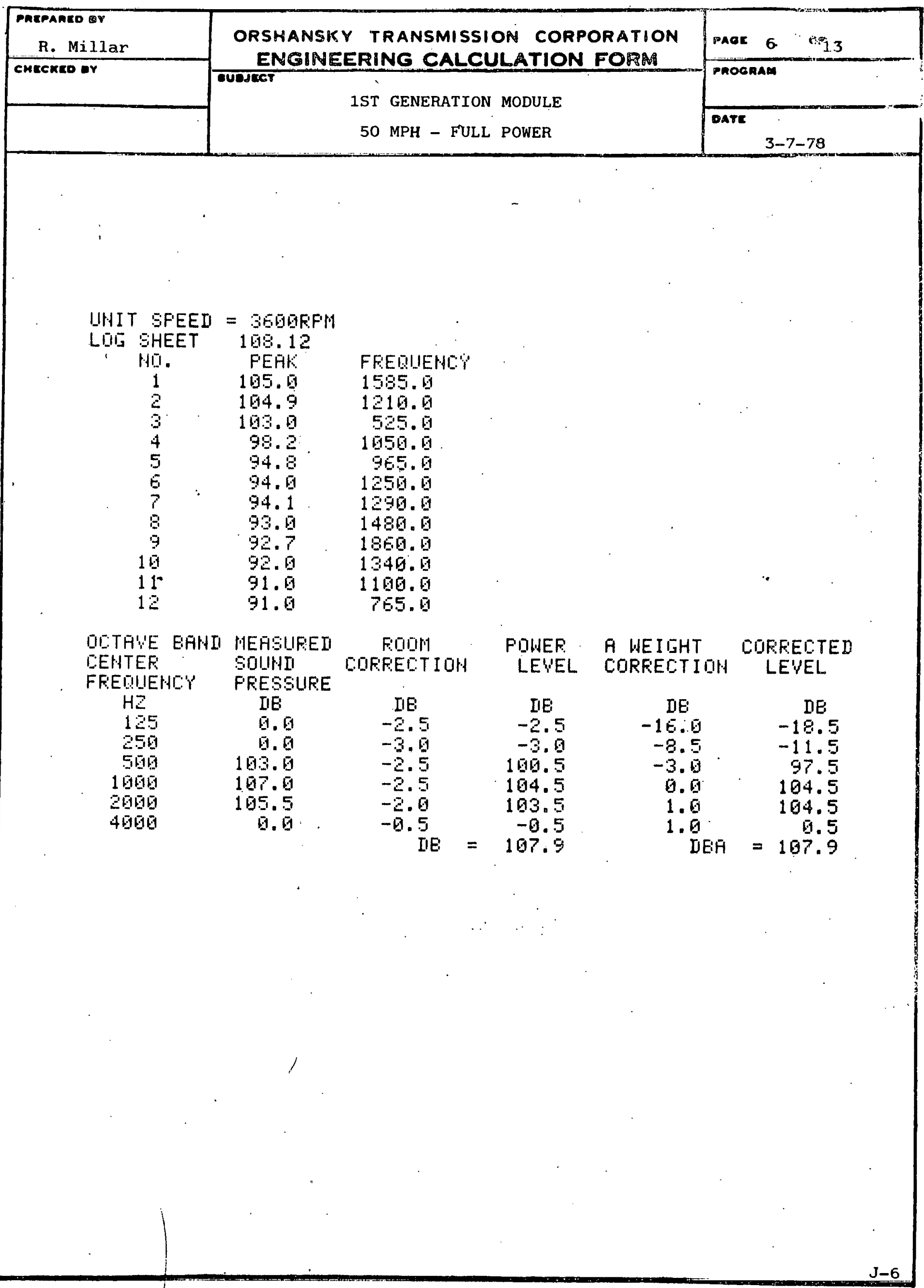




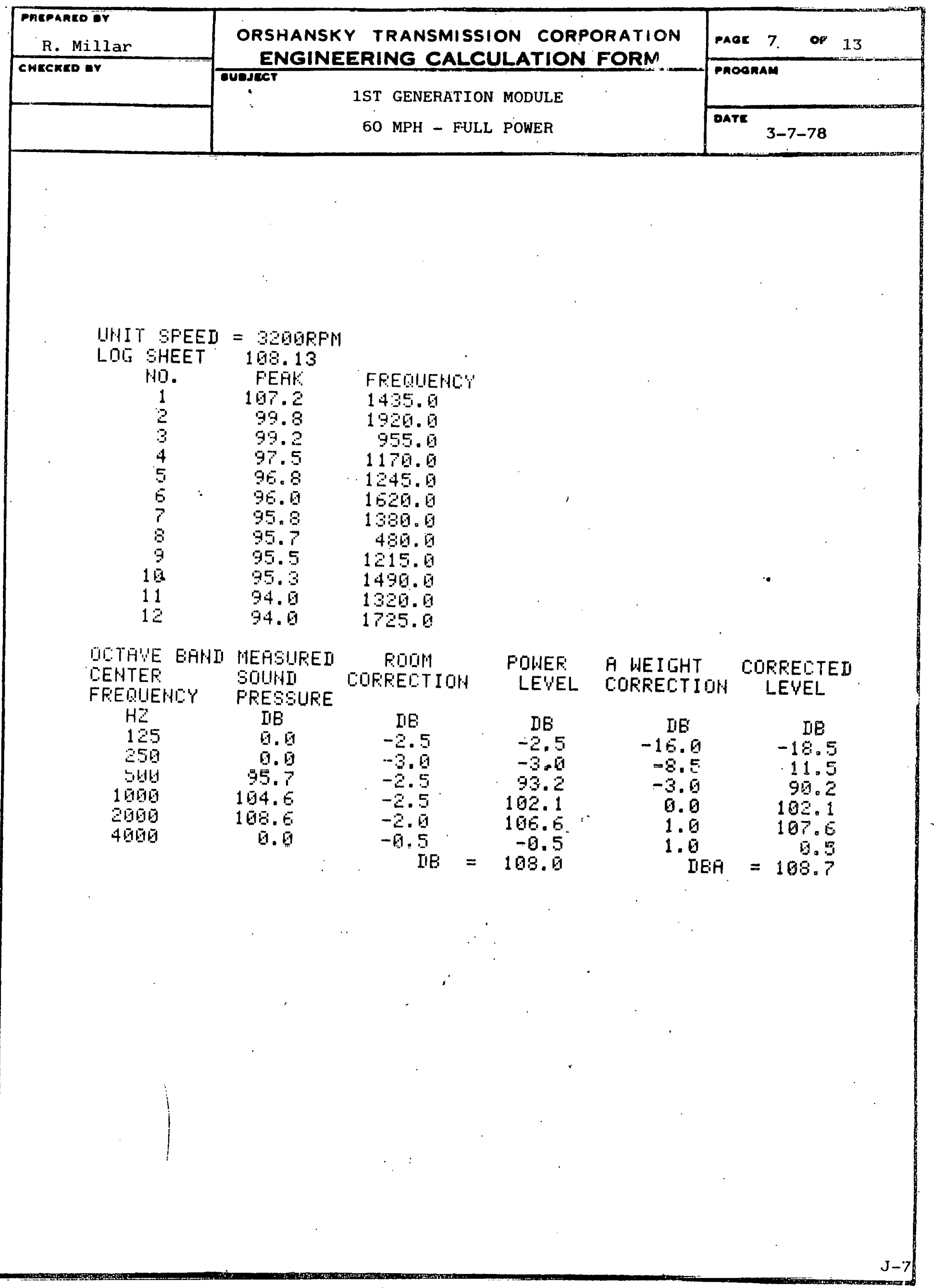




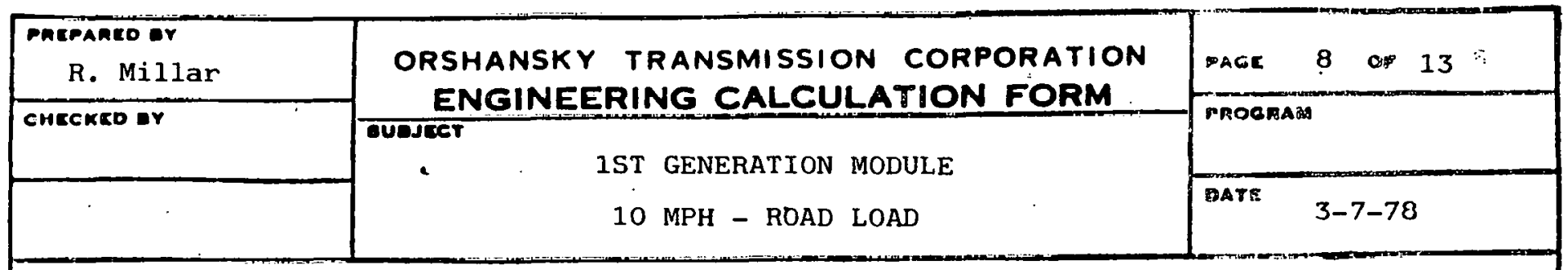

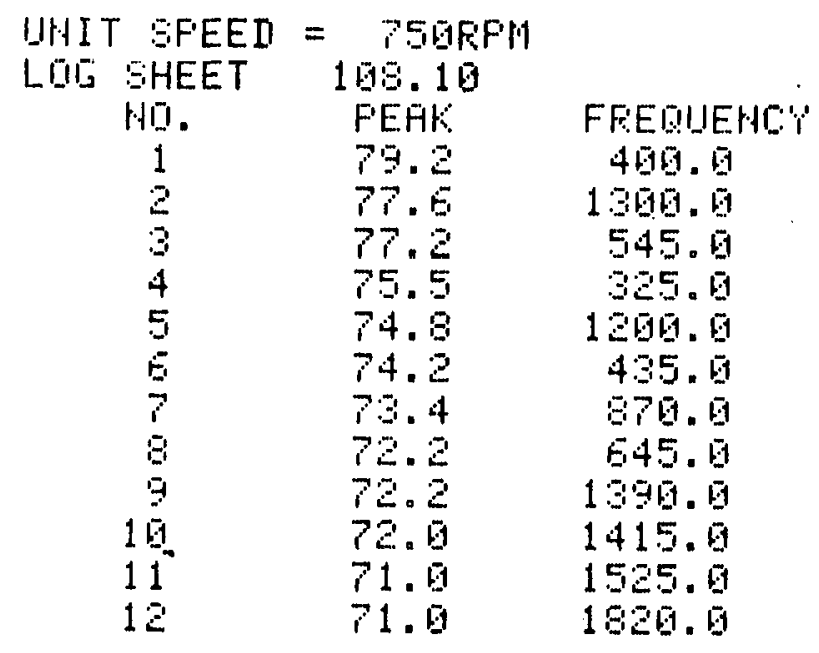

\begin{tabular}{|c|c|c|c|c|c|}
\hline $\begin{array}{l}\text { GLTHUE EAHI } \\
\text { CEHTER } \\
\text { FEEOUEHCY }\end{array}$ & $\begin{array}{l}\text { PEASUREI } \\
\text { SOUHII } \\
\text { FRESSURE }\end{array}$ & 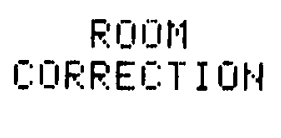 & $\begin{array}{l}\text { POWEF } \\
\text { LEWEL }\end{array}$ & $\begin{array}{l}\vec{H} \text { WE I SHT } \\
\text { GOFREET I OHA }\end{array}$ & $\begin{array}{c}\text { COFFECTEI } \\
\text { I.EVEL }\end{array}$ \\
\hline 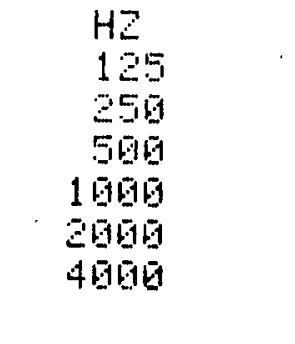 & $\begin{array}{l}\text { IDE } \\
0.6 \\
75.5 \\
85.5 \\
81.6 \\
76.1 \\
0.6\end{array}$ & $\begin{array}{c}\text { IE } \\
-2.5 \\
-3 \cdot 5 \\
-2.5 \\
-2.5 \\
-2.5 \\
-6.5 \\
\text { IIE }\end{array}$ & $\begin{array}{l}\text { IIE } \\
-2.5 \\
72.5 \\
60.6 \\
78.5 \\
74.1 \\
-0.5 \\
83.3\end{array}$ & $\begin{array}{c}\text { IIE } \\
-16.0 \\
-8.5 \\
-3.9 \\
0.0 \\
1.6 \\
1.0 \\
\text { DEA }\end{array}$ & $\begin{array}{r}\text { IIE } \\
-19.5 \\
64.0 \\
77.6 \\
78.5 \\
75.1 \\
=8.5 \\
81.9\end{array}$ \\
\hline
\end{tabular}




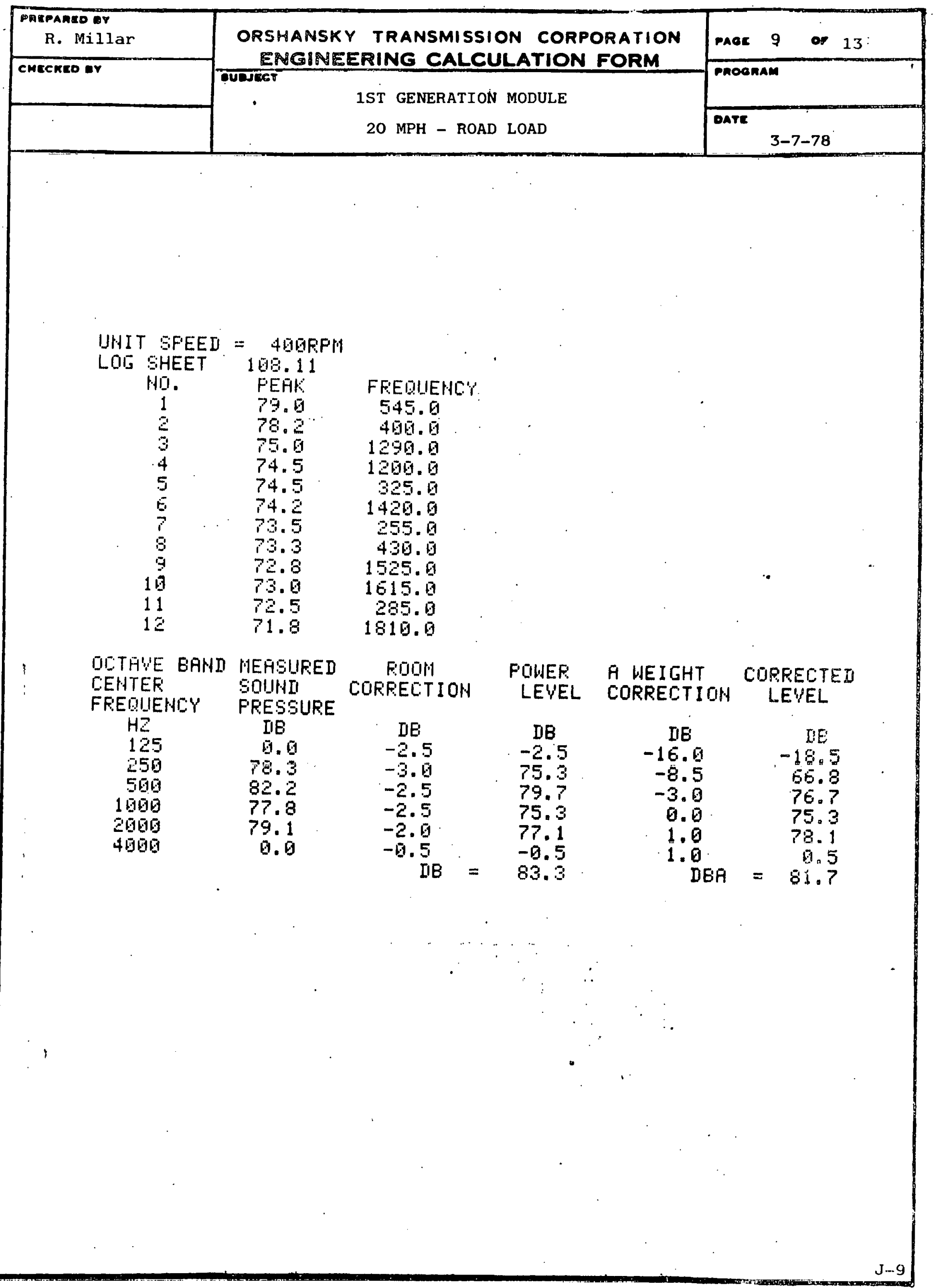




\begin{tabular}{|c|c|c|}
\hline $\begin{array}{l}\text { PAcenaco or } \\
\text { R.: Millar }\end{array}$ & ORSHANSKY TRANSMISSION CORPORATION & paCr 10 or 13 \\
\hline \multirow[t]{2}{*}{ CMECKED QV } & $\begin{array}{l}\text { ENGINEERING CALCULATION FORM } \\
\text { TUOTET }\end{array}$ & enoonam \\
\hline & $\begin{array}{l}\text { 1ST GENERATION MODULE } \\
30 \mathrm{MPH} \text { - ROAD LOAD }\end{array}$ & $3-7-78$ \\
\hline
\end{tabular}

I.HIT EFEEI = 9GGFFM

LOI SHEET 107.70

\begin{tabular}{|c|c|c|}
\hline $\begin{array}{c}40 . \\
1 \\
2 \\
3 \\
4 \\
5 \\
6 \\
7 \\
9 \\
9 \\
11 \\
11 \\
12\end{array}$ & $\begin{array}{l}\text { PEAK } \\
84.0 \\
79.0 \\
79.5 \\
77.9 \\
75.5 \\
74.5 \\
73.5 \\
72.5 \\
72.0 \\
72.0 \\
72.0 \\
71.5\end{array}$ & $\begin{array}{r}\text { FEEQIEHEY } \\
562.0 \\
1540.0 \\
985.0 \\
835.0 \\
710.0 \\
1290.0 \\
1575.0 \\
425.0 \\
295.0 \\
870.0 \\
1690.0 \\
1960.0\end{array}$ \\
\hline
\end{tabular}

\begin{tabular}{|c|c|c|c|c|c|}
\hline $\begin{array}{l}\text { IETHWE EAHI } \\
\text { EHTEF } \\
\text { REOULHCY }\end{array}$ & $\begin{array}{l}\text { MEASURED } \\
\text { SOUHI } \\
\text { FRESSURE }\end{array}$ & $\begin{array}{c}\text { FOOOM } \\
\text { COFEEITI IOHA }\end{array}$ & $\begin{array}{l}\text { FOWEF } \\
\text { LEVEL }\end{array}$ & $\begin{array}{l}\text { A WEILHT } \\
\text { CORREETIOH }\end{array}$ & $\begin{array}{c}\text { CORFEITEI } \\
\text { LEVEL }\end{array}$ \\
\hline $\begin{array}{r}42 \\
125 \\
250 \\
500 \\
1960 \\
2000 \\
4600\end{array}$ & $\begin{array}{r}I \mathrm{~B} \\
6.0 . \\
72.0 \\
64.3 \\
93.2 \\
81.2 \\
0.0\end{array}$ & $\begin{array}{c}\text { IE } \\
-2.5 \\
-3.6 \\
-2.5 \\
-2.5 \\
-2.6 \\
-0.5\end{array}$ & $\begin{array}{l}\text { II } \\
-2 \\
69 \\
61 \\
60 \\
79 \\
-0 \\
85\end{array}$ & $\begin{array}{c}\text { IIE } \\
-16.0 \\
-8.5 \\
-3.0 \\
0.0 \\
1.0 \\
1.0 \\
\text { IJE }\end{array}$ & $\begin{array}{r}\text { DE } \\
-19.5 \\
69.5 \\
78.8 \\
80.7 \\
80.2 \\
0.5 \\
84.8\end{array}$ \\
\hline
\end{tabular}




\begin{tabular}{|c|c|c|}
\hline $\begin{array}{l}\text { PREPAFEO OY } \\
\text { R. Millar }\end{array}$ & $\begin{array}{l}\text { ORSHANSKY TRANSMISSION CORPORATION } \\
\text { ENGINEERING CALCUILTION FORA }\end{array}$ & PAQE 11 OP 13 \\
\hline \multirow[t]{2}{*}{ CHECKED or } & OUDSECT & PROGRAM \\
\hline & $40 \mathrm{MPH}-$ ROAD LOAD & $3-7-78$ \\
\hline
\end{tabular}

LIHIT SFEEI = 12 GQFFH

LOE SHEET 1 GE.14

$\begin{array}{cl}11 . & \text { FEAG } \\ 1 & 94.5 \\ 2 & 90.9 \\ 3 & 69.2 \\ 4 & 79.2 \\ 5 & 78.2 \\ 6 & 76.2 \\ 7 & 75.6 \\ 6 & 75.6 \\ 9 & 74.6 \\ 19 & 74.5 \\ 15 & 74.6 \\ 12 & 73.9\end{array}$

FFEQUEHL

730.0

360.6

990.0

1296.8

1640.0

58.6

1250.0

26日.

290.6

97.

950.0

156.6

\begin{tabular}{|c|c|c|c|c|c|}
\hline 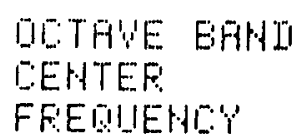 & $\begin{array}{l}\text { MEFGUFEI } \\
\text { GUDHI } \\
\text { FFEGSUFE }\end{array}$ & 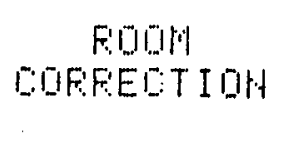 & $\begin{array}{l}\text { FOWEFE } \\
\text { LEVEL }\end{array}$ & $\begin{array}{l}\text { A WEIEHT } \\
\text { GOFEEET IOH. }\end{array}$ & $\begin{array}{l}\text { LOFEELTED } \\
\text { LEWEL }\end{array}$ \\
\hline $\begin{array}{l}42 \\
125 \\
256 \\
500 \\
1060 \\
2060 \\
4609 .\end{array}$ & $\begin{array}{c}\text { IIE } \\
7.9 \\
77.9 \\
94.3 \\
96.4 \\
79.2 \\
9.6\end{array}$ & $\begin{array}{c}\text { IIE } \\
-2 \cdot 5 \\
-3 \cdot 5 \\
-2 \cdot 5 \\
-2 \cdot 5 \\
-2 \cdot 6 \\
-8 \cdot 5 \\
\text { IIE = }\end{array}$ & $\begin{array}{l}\mathrm{TE} \\
71.5 \\
74.9 \\
91.5 \\
93.9 \\
75.2 \\
-6.5 \\
96.9\end{array}$ & $\begin{array}{c}\text { IE } \\
-1 E \cdot 0 \\
-8.5 \\
-3.6 \\
0.0 \\
1.0 \\
1.0 \\
\text { DIA }\end{array}$ & $\begin{array}{l}\text { TE } \\
5.5 .9 \\
65.4 \\
79.8 \\
63.9 \\
77.2 \\
9.5 \\
85.8\end{array}$ \\
\hline
\end{tabular}




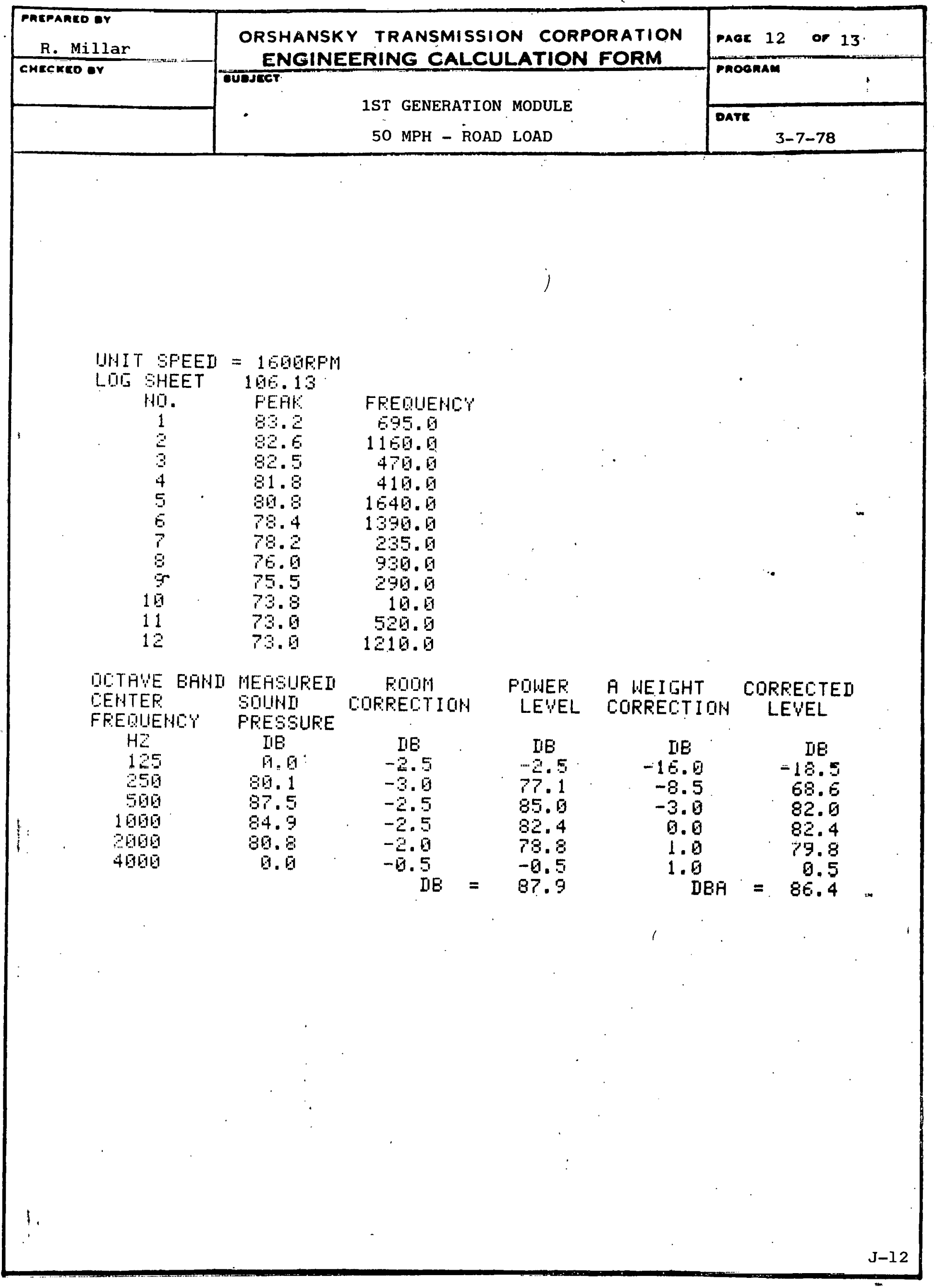




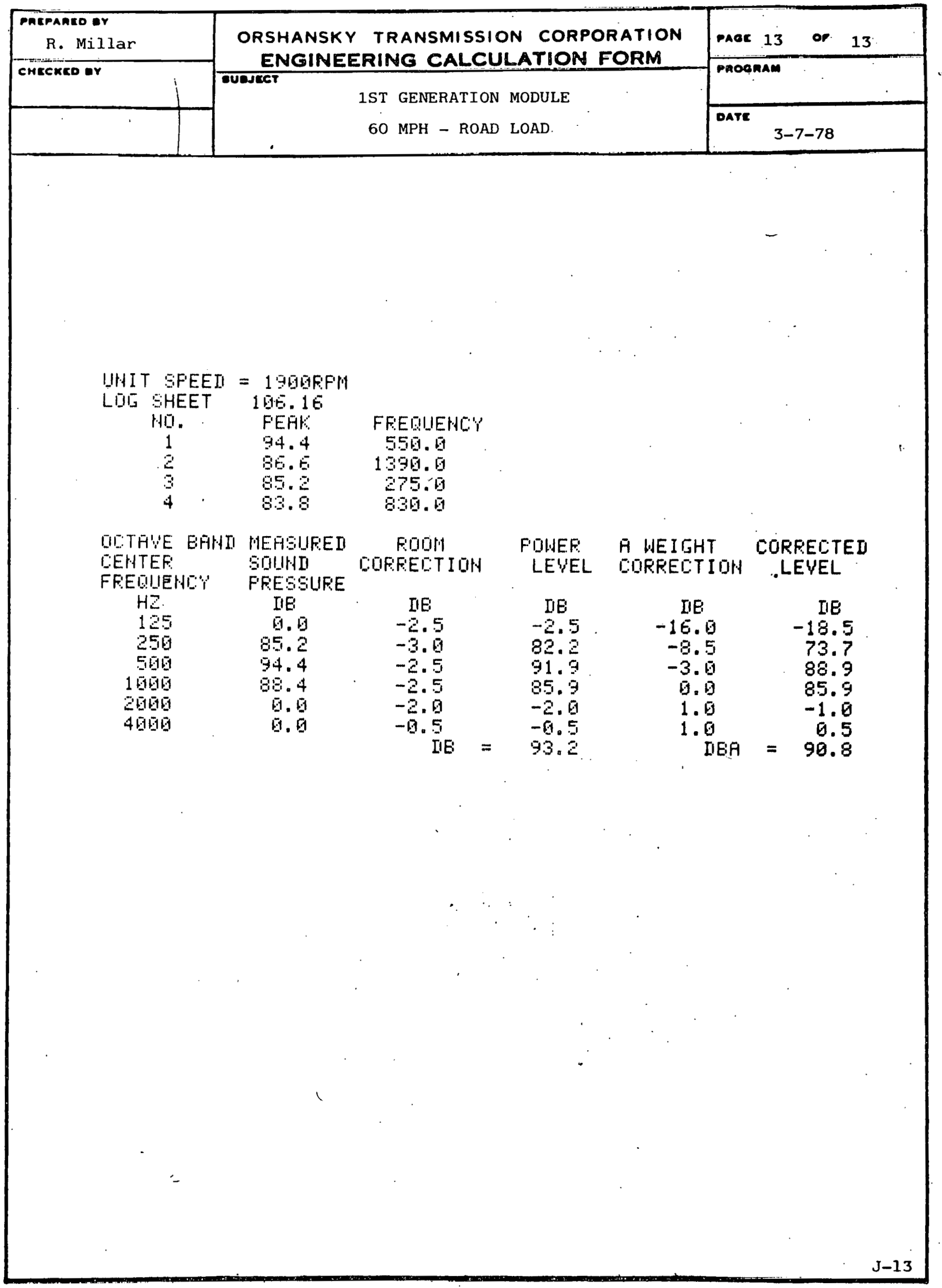




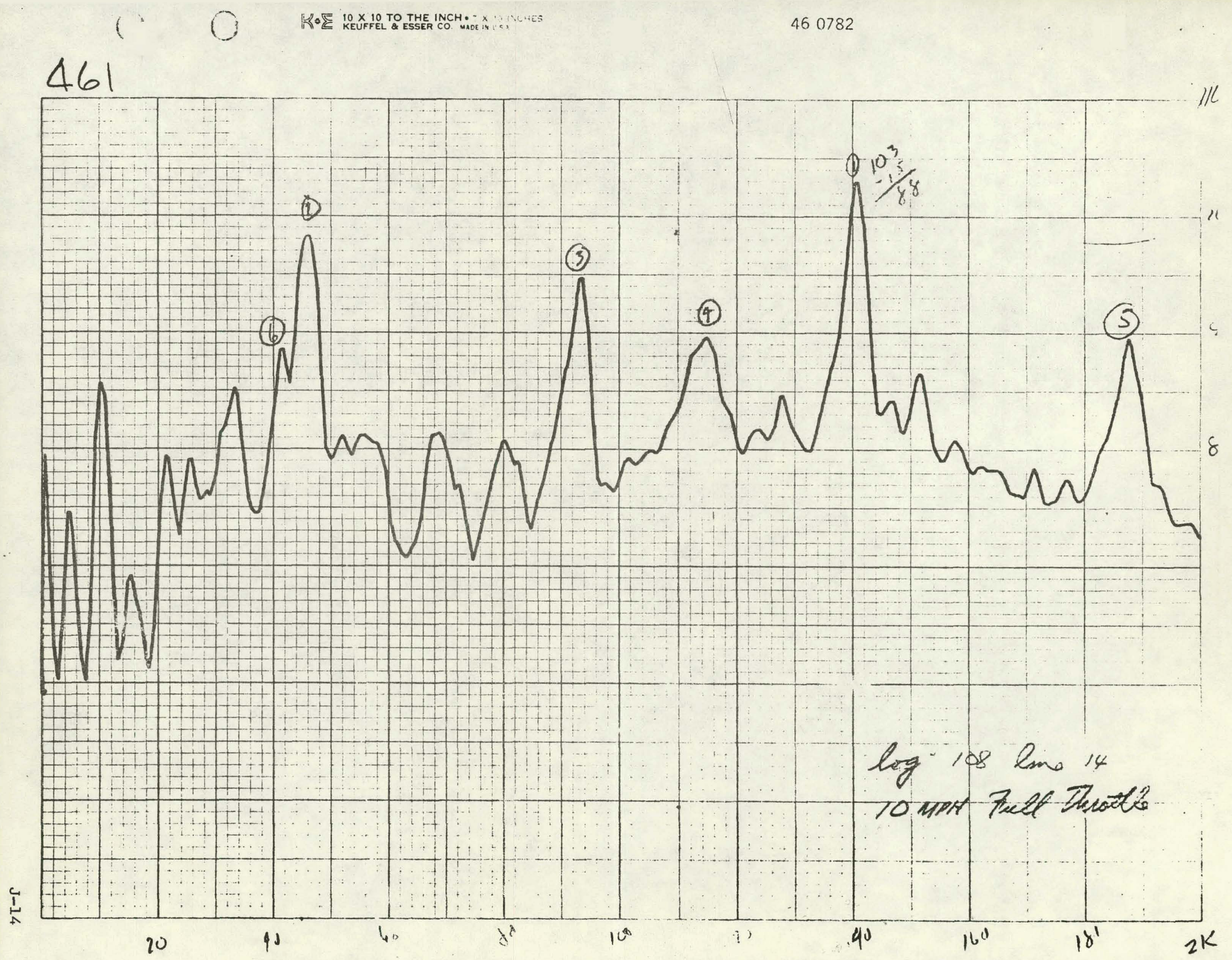




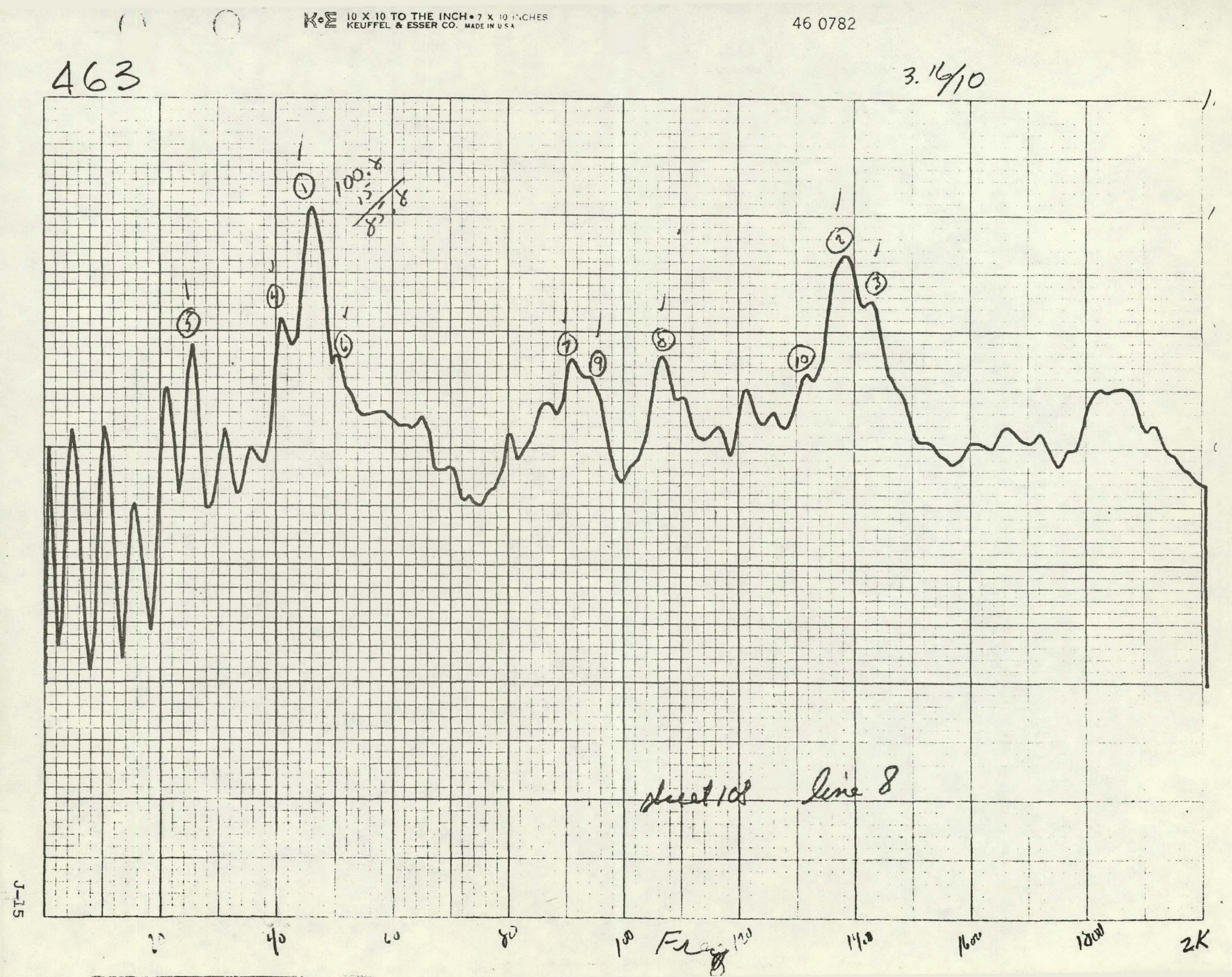


449

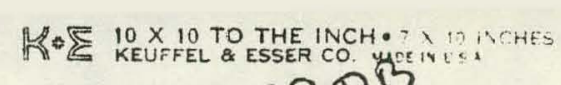

460782

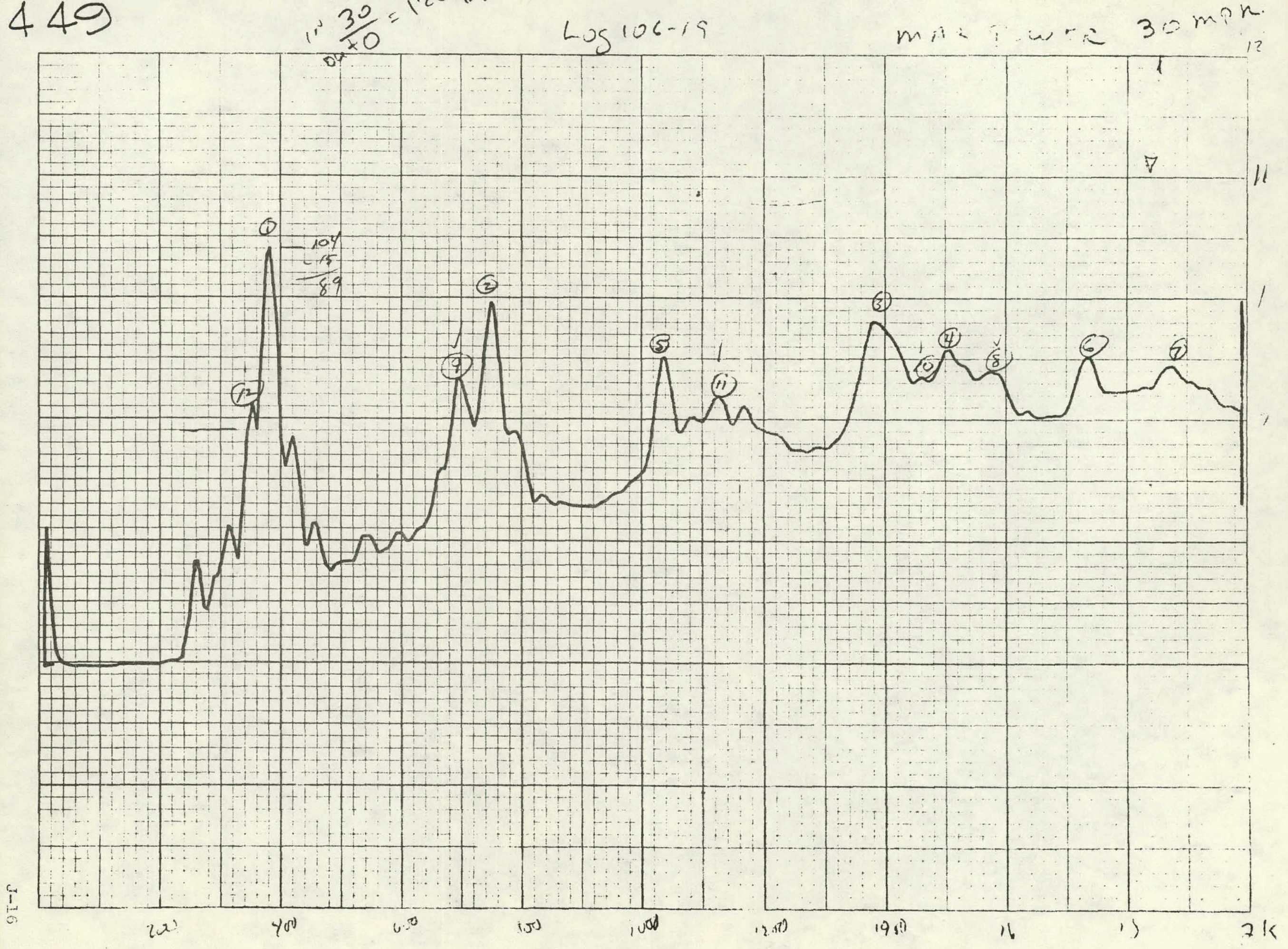




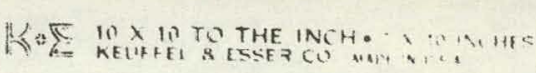

460782

465

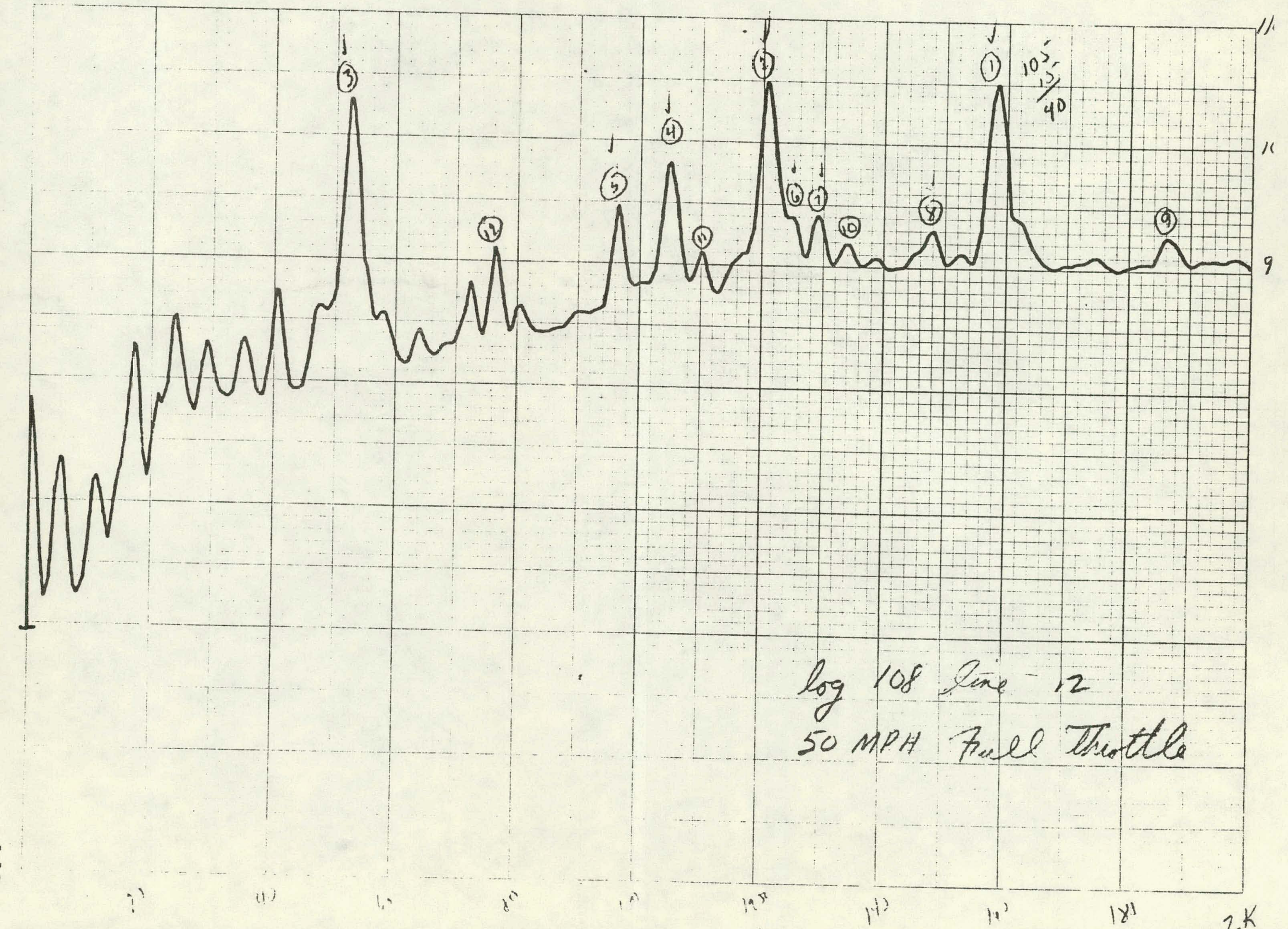




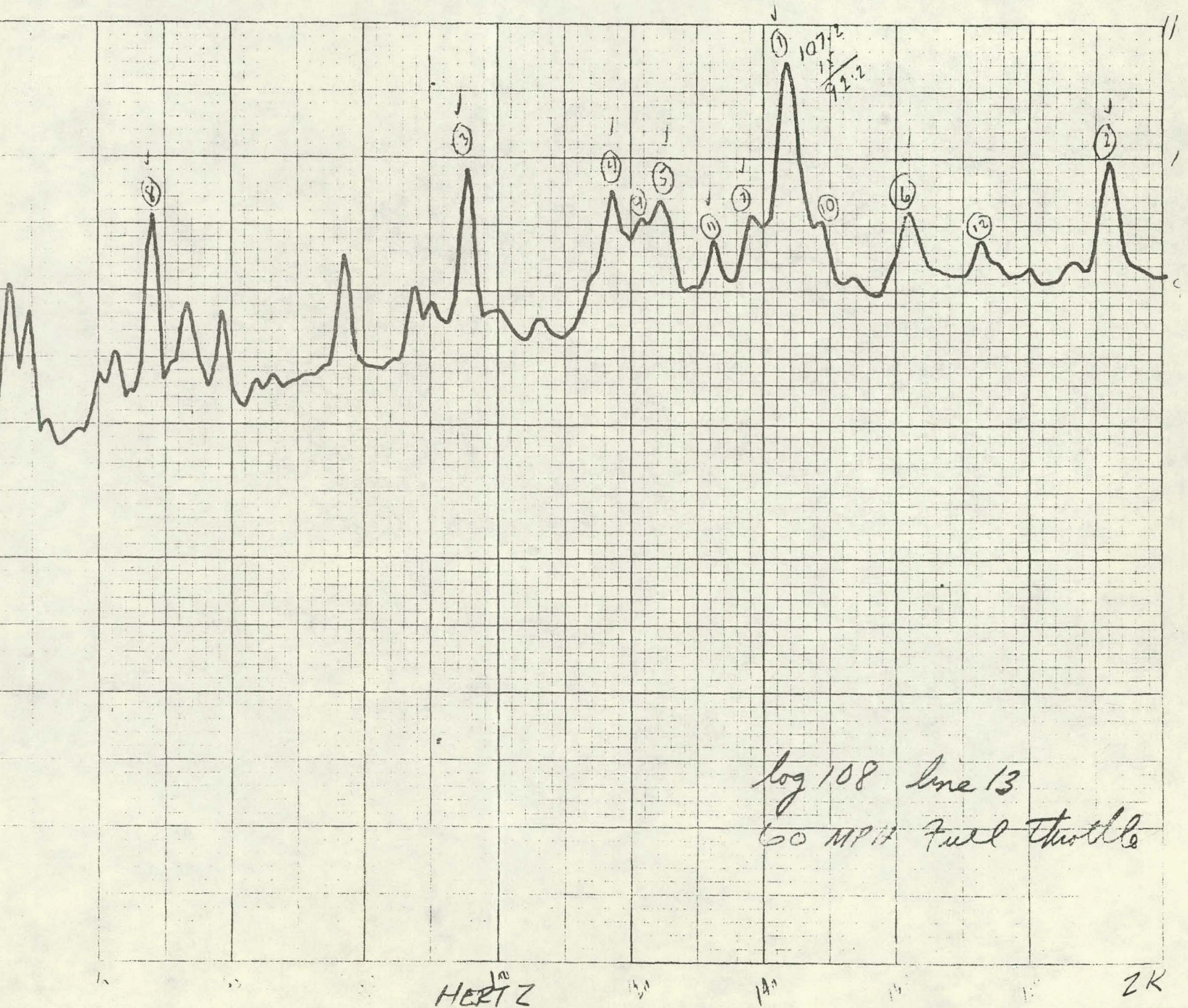


46c)

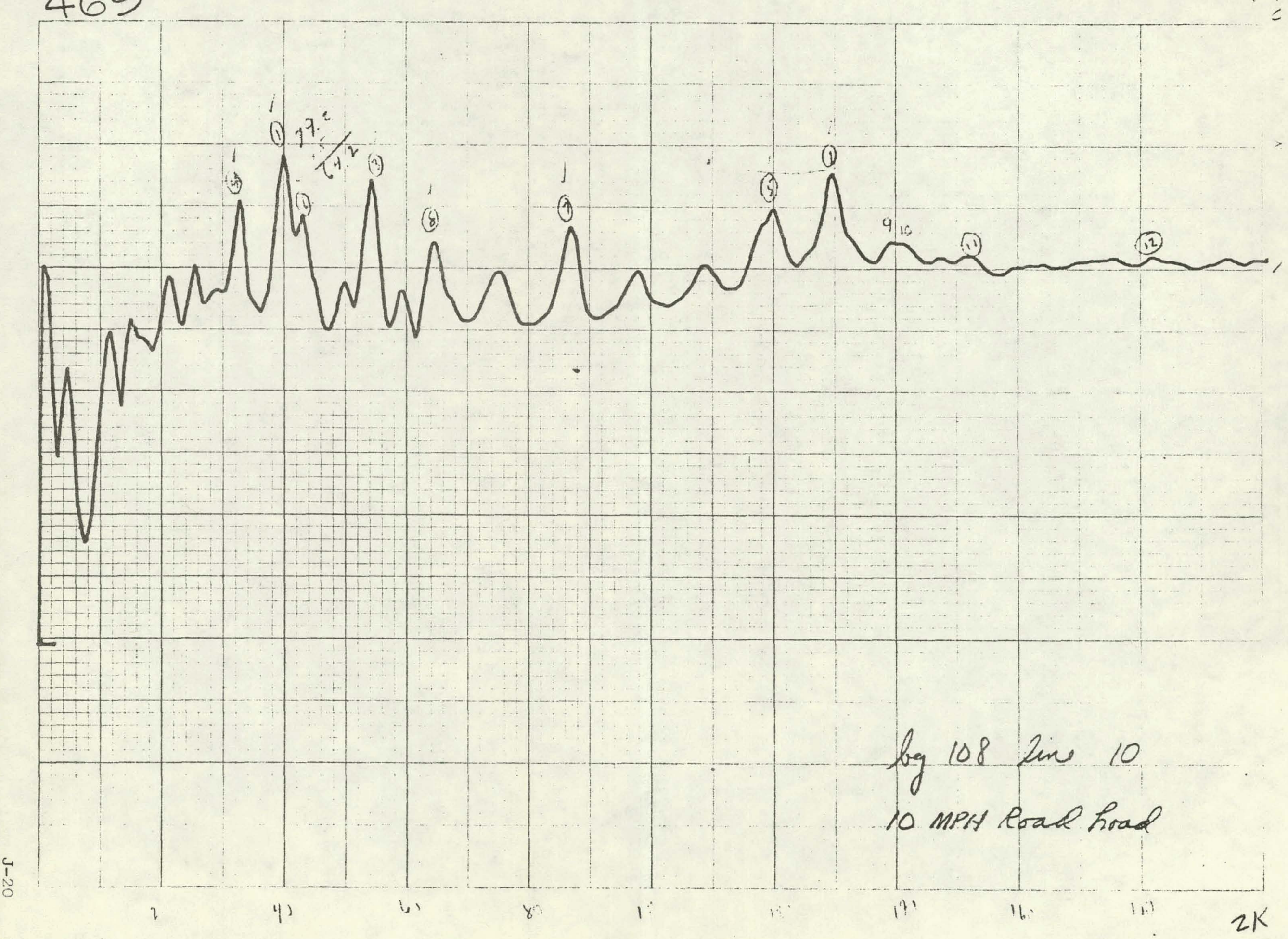




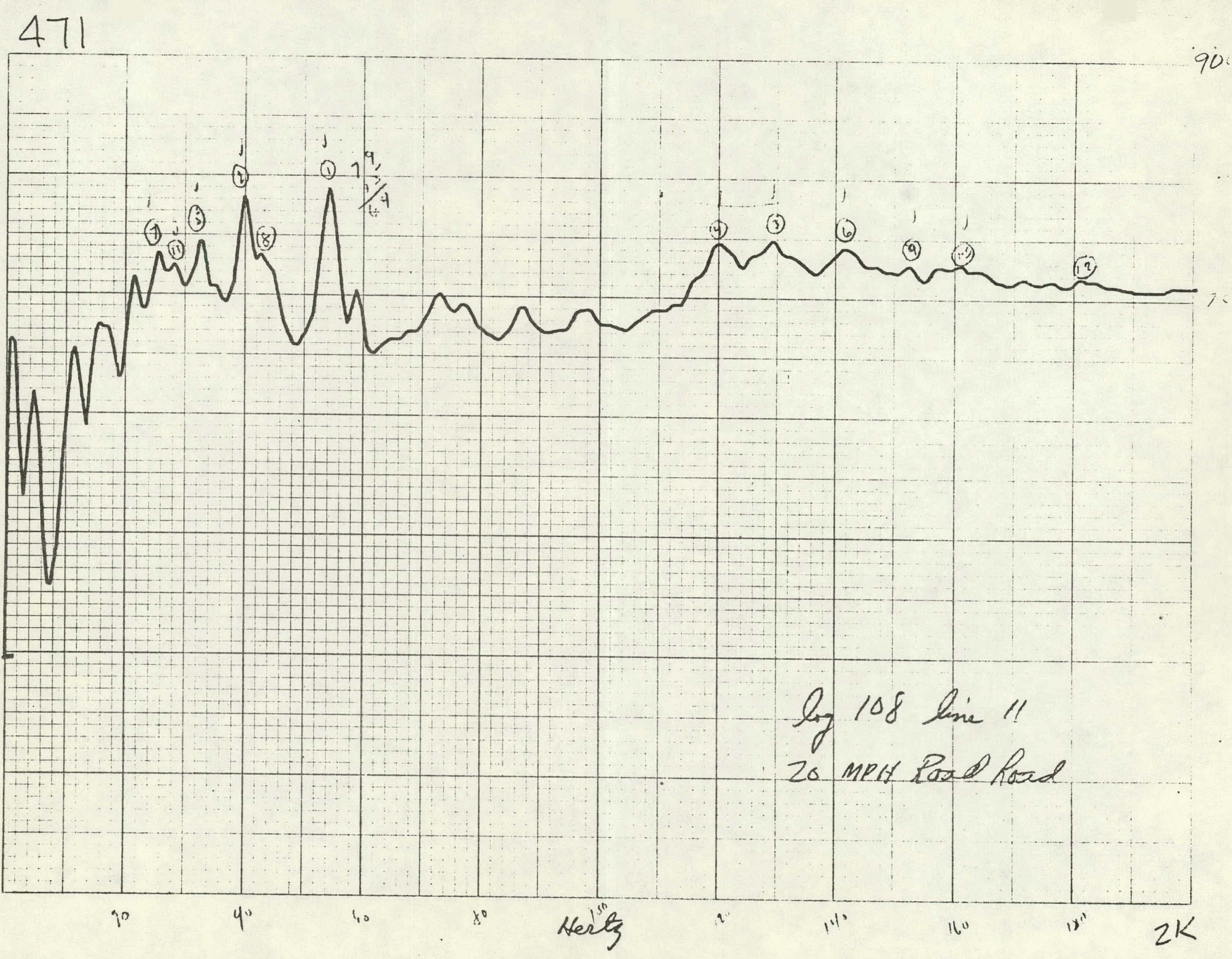




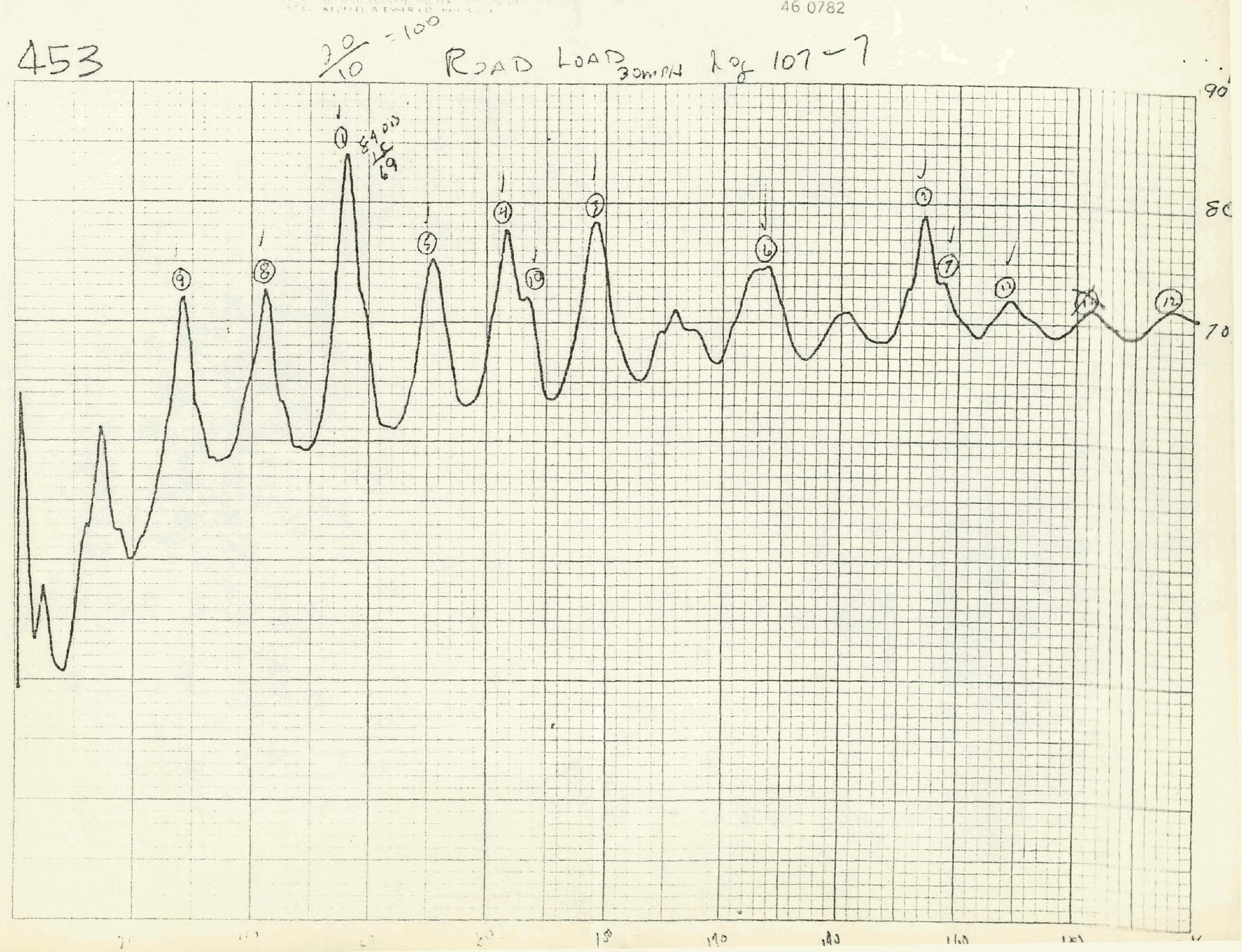


455

$\log 106-4$

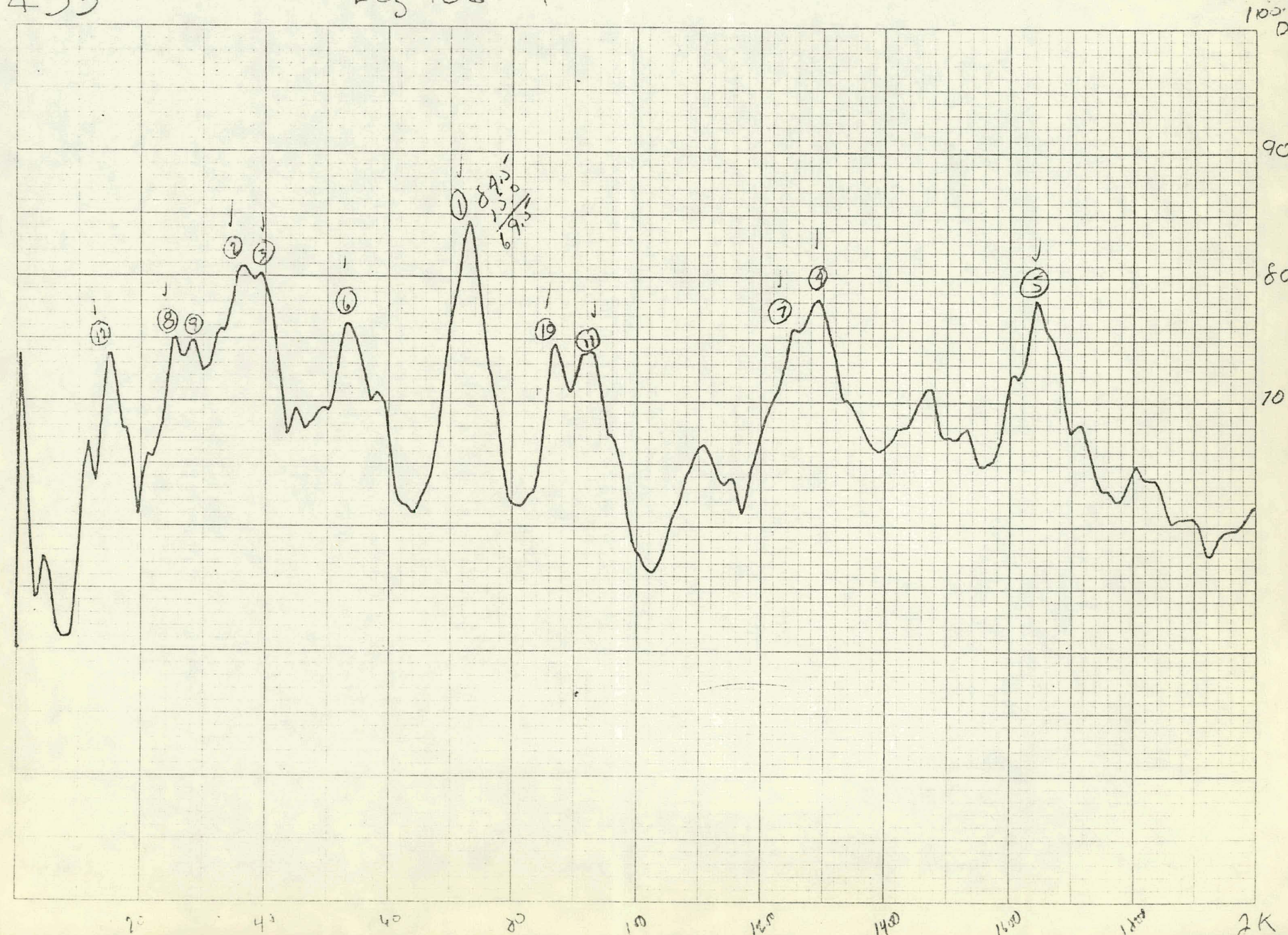


457 Rriw Noise ion-19

$100 \mathrm{I}$

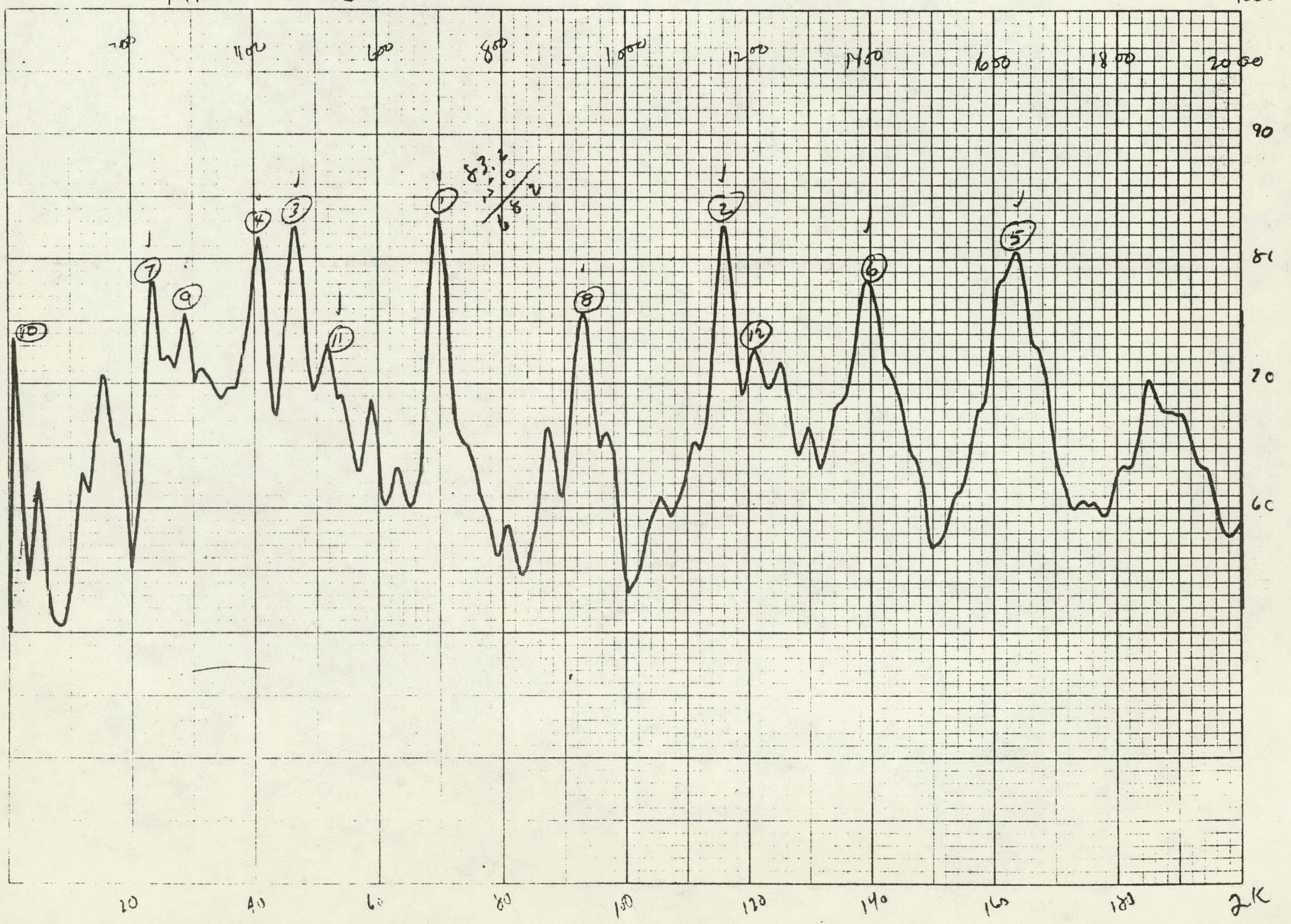




\section{APRIL 11, 1978 PROJECT REVIEW MEETING}

\section{ATTENDEES:}
P. Huntiey
J. Pratt
W. We seloh
B. Huffman
D. Connett
G. O1sen
K. Rudol ph
N. Postma
T. Stockton
P. Mann1ng
H. Themak
R. Parker

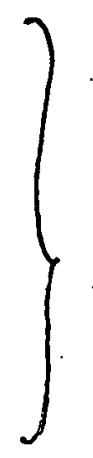

Orshansky Transmission

Corporation

$$
\}
$$

Ford Motor Company

TARADCOM, Warren, MI

Dept. of Energy, Washington D.C.

NASA Lewis Research Center 
A G E N D A

April 11 and 12,1978

Huntley's Office

8:00 A.M. - 8:30 A.M. Introduction, Huntley

Outline project,purpose of meeting.

Explain current status - no nolse data.

What we hope to accomplish today without nolse results.

Arrangements for Meeting

$8: 30-9: 15$

Review efficiency data on In-L1 ne Hydrostatic Module for

Second Generation HMT, D. Connett

Summarize current status and problems.

Tests we have run.

Theories on nature of problem.

Design philosophy - comparison with other units.

Review efficiency results.

$9: 15-9: 30$

Review noise data for First and Second Generation

Moduleg, $\mathbf{K}$. Rudolph/

Definition of test points.

Results.

Further port-plate modificationg.

$9: 30-10: 15$

Digital Controller, Description, B. Huffman

Review evolution of controllers.

Method of operation and special features of digital controller.

$10: 15-10: 30$

Digital Controller Application, w. Weseloh

Examples of controller application.

$10: 30-12: 00$

Meeting divides into two groups, each group spending

45 minutes on each of the following topics: 


\section{ORSHANSKY TRANSMISSION CORPORATION}

10:30 - 12:00 con't

(a) Acousting Test Cell

Instrumențațion and measurement procedure, J. Pratt,

K. Rudolph.

Run Module.

Run tape recorder.

(b) Test Drive Demonstration Vehicle, B. Huffman,

w. Weseloh

Evaluation of control function and noise.

Illustration of controller capabilities.

$12: 30-1: 30$

Botsford's Restuarant, Lajolla

Buffet luncheon.

$12: 30-1: 30$

Review Second Generat1 on Transm1ssion Design

Require drawings, Design calculations, Hydraulic

controls, K. Rudolph, W. Weseloh

$1: 30-2: 30$

Profected efficiency of Becond Generation HarT, P. Huntley

Printout.

May, 1977, Progress Report.

Test data on Gerotor.

$2: 30-3: 30$

Plans for completion of Second Generation Hur, W. Weseloh

Bar chart, man hours, major purchases.

$3: 30-4: 30$

Commentary by Ford

$4: 30$

- Adjournment 
Transmission Evaluation - Orshansky Hydromechanical

\begin{tabular}{|c|c|c|c|c|c|c|c|c|c|c|}
\hline & 1 & 2 & 3 & 4 & 5 & 6 & 7 & $8^{\circ}$ & 9 & 10 \\
\hline $\begin{array}{l}\text { Noise } \\
\text { Idle }\end{array}$ & & & 0 & & X & & & & & \\
\hline Acce I & 0 & $\mathrm{X}$ & & & & & & & & \\
\hline Decel & & & 0 & $\bar{X}$ & & & & & & \\
\hline Steady State & & & & 0 & $\mathrm{X}$ & & & & & \\
\hline $\begin{array}{l}\text { Shift Quality } \\
\text { Opshift } \\
\text { Part Throttle } \\
\text { W.O.T. }\end{array}$ & $\frac{0}{0}$ & $\frac{x}{y}$ & & & & & & & : & \\
\hline $\begin{array}{l}\text { Wownsifift } \\
\text { Kickdown }\end{array}$ & 0 & $\begin{array}{l}x \\
0 X \\
\end{array}$ & & & & & & & & \\
\hline Decel & & 0 & & & $\mathrm{x}$ & & & & & \\
\hline $\begin{array}{c}\text { Vibration } \\
\text { Idlo }\end{array}$ & & & & & 0 & $x$ & & & & \\
\hline Accel & & & & $0 x$ & & & & & & \\
\hline Decel & & & & & 0 & $\bar{X}$ & & 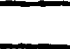 & & \\
\hline Steady State & & & & & & $0 x$ & & & & \\
\hline $\begin{array}{l}\text { Engagement } \\
\text { N-D Engagement }\end{array}$ & & 0 & & & & & & & $x$ & \\
\hline Ni-R. Enzagement & & 0 & & & & & & & $\frac{\Lambda}{X}$ & \\
\hline D-il Disengageuent & & & 0 & & & & & & $\bar{X}$ & \\
\hline R-N Disengagenent & & _ & 0 & - &. & & & - & $\mathrm{X}$ & \\
\hline- & & & & & & & & & & \\
\hline $\begin{array}{l}\text { Fun to Drive } \\
\text { General Appraisal }\end{array}$ & & $\begin{array}{l}x \\
0 \\
\end{array}$ & $\mathrm{X}$ & & & & & & & \\
\hline
\end{tabular}

October 1976 Assessmer:: 0

October 1977 Assessmert: X 
Project Review Meeting - April 11, 1978

Vehicle: 1978 NOVA

Transmission Evaluation - Orshansky Hydromechanical

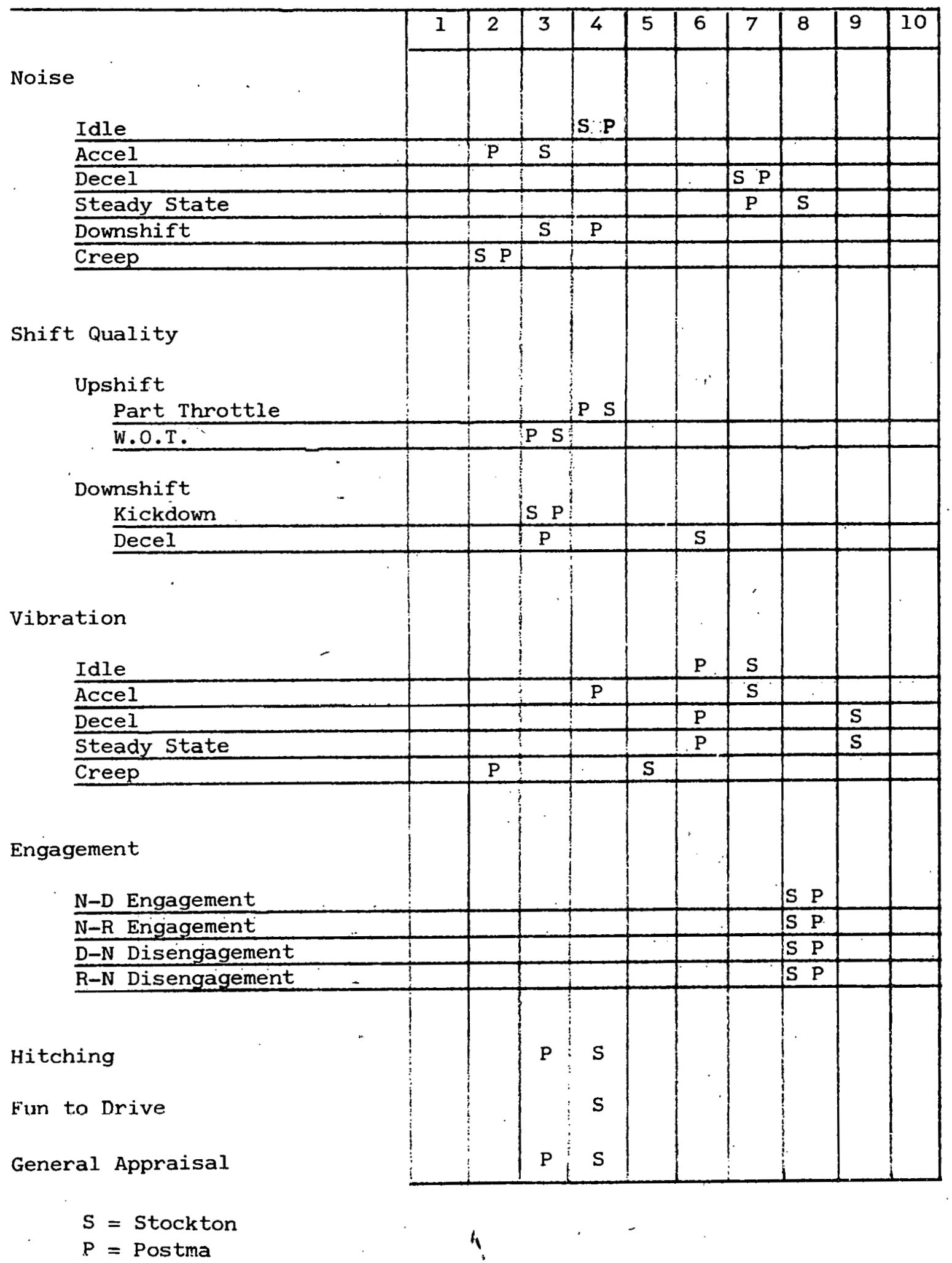

